\title{
Realizaciones arquitectónicas de la segunda mitad del siglo XVIII en los interiores de las catedrales góticas españolas
}

\author{
José Enrique García Melero
}

Las catedrales góticas, colosales máquinas arquitectónicas susceptibles biológicamente de cambios continuos, fueron objeto de numerosas intervenciones artísticas tanto en sus exteriores como en los interiores durante el transcurso de la segunda mitad del siglo XVIII. Se partía, así, de un necesario hábito secular, debido a la concurrencia de causas múltiples: a la conclusión o realización de partes no hechas antes; a la reconstrucción, e incluso a la restauración, de determinadas zonas dañadas por el paso del tiempo y los fenómenos naturales; a las nuevas necesidades litúrgicas de la época y de mayores espacios aprovechables para diversas funciones; a planteamientos arquitectónicos novedosos contrarios a viejas prácticas; a la casi obligación de cumplir los deseos de Obispos y demás mecenas, que daban en vida o legaban testamentariamente ciertos caudales para la realización de obras diversas, inspiradas por su religiosidad y devociones a ciertos santos o por la idea de dejar huella de su presencia en la vida...

Tales templos catedralicios, iniciados en los siglos caballerescos, experimentaron cambios continuos en su aspecto, adecuándose a las nuevas fórmulas. Historias vivas y dinámicas del arte, en sus piedras se hallan los vestigios del ir y venir y del mezclarse de los estilos. Sus tamaños casi faraónicos propiciaban la posibilidad de una continua actividad constructiva y la concurrencia de los arquitectos más importantes de cada momento, que empleaban bien lenguajes anclados en el pasado o más o menos novedosos y, a veces, hasta revolucionarios. Monumen- 
tales escenarios litúrgicos, lo fueron también de debates y polémicas entre los artistas, cabildos y mecenas a la hora de optar por determinadas funciones, formas y estilos.

Las intervenciones arquitectónicas hechas en los interiores de las catedrales góticas españolas durante la segunda mitad del siglo XVIII fueron mucho más numerosas que las llevadas a cabo en sus fachadas ${ }^{1}$. Este capitulo es, sin duda, el más complejo de todos ellos debido a su heterogeneidad. Así, al mismo tiempo que se depuraban esos templos de viejos retablos de madera y se construían nuevas sacristías, retablos y capillas, se renovaban los enlosados y hasta no falta la remodelación de todo un interior, tal y como ocurrió en la catedral de Valencia, estudiado recientemente por Bérchez ${ }^{2}$. Por lo general, tales transformaciones suelen compartimentarse en espacios más o menos aislados, sin mezclarse con manifiesta discordancia con la realidad del entorno gótico, que frecuentemente se respeta con un afán historicista, como testimonio de otra época ya distante en el tiempo. Participan de la complejidad estilística del momento, pues se oscila desde el empleo de unas formas barrocas, y aún a veces rococós, a un barroco más o menos clasicista y a otras ya más depuradas, dependiendo todo ello tanto de sus diferentes cronologías dentro de este período como de las distintas formaciones, concepciones y estados evolutivos de sus arquitectos, y de los núcleos geográficos, a los que pertenecen.

También hay que añadir a estas directrices generales la intención de cambiar de lugar los coros, colocándolos detrás del Altar Mayor, en el retrocoro, o rodeando el presbiterio, como es el caso del proyecto de Ventura Rodríguez de 1755 para la Catedral del Burgo de Osma. Según Rodríguez de Ceballos ello obedeció tanto a las influencias de los modelos italianos del Quinientos, de Palladio, de Herrera y de Juvarra como a la idea de volver a hábitos constructivos de la iglesia primitiva promovida por el jansenismo ${ }^{3}$. Se deseaba crear, así, un espacio abierto en el

José Enrique Garcia MELERo, «Transformaciones arquitectónicas de la segunda mitad del siglo XVIII en los exteriores de las catedrales góticas españolas». En prensa: Hispania Sacra. Madrid 1989, 32 pág.

2 Joaquin BERCHEZ, Los comienzos de la Arquitectura académica en Valencia: Antonio Gilabert. Valencia, Ed. Federico Domenech, 1987. Dedica el capitulo V, pág. 97-157 a «La remodelación clasicista de la Catedral de Valencia". Su trabajo, exhaustivo y de gran riqueza interpretativa, se basa en la documentación del Archivo de la Catedral de Valencia (sección de planos y Libro de Fábrica), así como en numerosa bibliografía tanto local como general.

3 Alfonso Rodriguez G. DE Ceballos, «La reforma de la arquitectura religiosa en el reinado de Carlos III. El neociasicismo español y las ideas jansenistas". Fragmentos, núms. 12-14. Madrid, Ministerio de Cultura, junio 1988, pág. 115-127. 
interior de los templos, que permitiera, además de su contemplación panorámica, la visibilidad del Altar Mayor, frente a las compartimentaciones barroquizantes.

Los arquitectos más importantes de la época se ocuparon de diseñar estas obras. En ellas trabajaron maestros como Ventura Rodríguez, Juan de Villanueva, Sabatini, Antonio Gilabert, Pedro Arnal... La simple enumeración de estos nombres habla por si misma de la ambición de los proyectos y de las realizaciones, en donde a veces se encuentran y suceden varios de ellos, como es el caso, por ejemplo, de la Catedral del Burgo de Osma o del trascoro de la Catedral de Segovia. Ventura Rodríguez estuvo presente en muchas de ellas, pues actuó en las catedrales de Cuenca, Burgo de Osma (Soria), Toledo, Pamplona y Segovia, interviniendo también de alguna forma en las de Almería y Lugo.

Una característica casi común a todas estas obras realizadas en los interiores de los templos góticos llama poderosamente la atención: el uso de materiales nobles como los mármoles y jaspes de diferentes procedencias y de distintos colores, y el bronce. Su uso combinado no sólo contribuyó a dotarlas de ricos efectos polícromos, sino a dignificar y embellecer los diseños, a hacerlas más perdurables evitando además los incendios, que tan tristes consecuencias habian producido en estas catedrales y hasta a economizar mucho dinero al prescindirse de los paneles dorados con que se revestian los retablos de madera ${ }^{4}$. Asi ocurre, por ejemplo, en las realizaciones de Ventura Rodríguez para la Catedral de Cuenca, o en el Altar Mayor de la de Segovia, diseñado por Sabatini, cuya idea parece estar presente en la redacción, bajo la clara inspiración de Antonio Ponz, de la carta circular de Carlos III del 25 de noviembre de $1777^{5}$. De esta forma, frente al predominio de la madera dorada en las obras hechas anteriormente, por lo general en los retablos, sucede ahora el uso prioritario de unos materiales más ricos y dignos.

4 Alfonso Rodriguez G. DE Ceballos, “La reforma...", pág. 119, y Juan José MartíN GONZALEZ: "Problemática del retablo bajo Carlos IIl". Fragmentos, núms. 12-14. Madrid, Ministerio de Cultura, junio 1988, pág. 33-43.

5 1777, noviembre 25: Circular expedida por la via de Estado a los Obispos, Caballeros y Prelados por D. Carlos III sobre el modo de executar las obras ocurrentes en todas las iglesias y sus altares, mediante consulta a la Academia de San Fernando. (Nov. Rec., libro I, tit. II, Ley V). En el Archivo de la Academia de San Fernando se conservan varios ejemplares en 2-32/7. 


\section{LOS PROMOTORES DE LAS OBRAS}

Las obras realizadas durante esta época en nuestras catedrales góticas fueron generaimente promovidas por el mecenazgo eclesiástico. Obispos y cardenales encargaron estas construcciones ya en vida o legando sus bienes en los testamentos para que después otros prelados las hicieran. Así ocurrió, por ejemplo, en la Capilla de San Julián y en el altar mayor del templo catedralicio de Cuenca, erigidos entre 1755 y 1760 por Ventura Rodríguez en tiempos de los Obispos José Flórez Osorio, y Carvajal y Láncaster, su sucesor, con la herencia dejada en 1705 por el también Obispo Antonio Alonso de San Martín, hijo natural de Felipe IV.

No obstante, el patrocinio regio, que corrió en ocasiones con la mayoría de los costes de determinadas realizaciones, se interfirió algunas veces en el mecenazgo de tales obras. Este hecho ocasionó -concretamente en el trascoro de la Catedral de Segovia, en donde se colocó el retablo mayor de Huberto Demandre de la capilla del palacio de Riofrío en 1783 - cierta polémica entre las jerarquías eclesiásticas y reales al enfrentarse dos concepciones arquitectónicas opuestas, defendidas por otras tantos maestros, y posteriores soluciones conciliadoras y eclécticas. Pero también la aportación de la Corona enriqueció considerablemente la construcción con la presencia de los arquitectos más significativos del momento. Así ocurrió en las realizaciones de la catedral de Burgo de Osma (Soria), en donde se encontraron o sucedieron Ventura Rodríguez, Sabatini y Juan de Villanueva entre 1770 y 1781 . El patronazgo regio propició la construcción de obras modélicas como la del Altar Mayor de la Catedral de Segovia, diseñado por el italiano.

Los cabildos catedralicios desempeñaron entonces una función muy importante al velar por estas transformaciones. Sus juicios pesaron sobre ellas muchas veces casi tanto como los emitidos por la misma Real Academia de Bellas Artes de San Fernando, asumiendo, casi siempre, una actitud totalmente tradicionalista. Esto ocurrió, por ejemplo, al rechazarse el proyecto de Ventura Rodríguez para la fachada principal de la Catedral de Toledo en 1773. En ocasiones promovieron, o consintieron, actuaciones totalmente al margen de esta institución, como en los retablos de Melchor de Prado para el templo catedralicio de Lugo. Sin embargo, todo ello no impidió que algunos canónigos - Joaquín Antonio del Camino en Lugo y Joaquín de Herrera Lorenzana en León- denunciaran ciertas prácticas arquitectónicas hechas sin la supervisión y el permiso de la 
Academia en las postrimerías del siglo de la llustración y en los inicios del XIX.

Pero, aunque las aportaciones reales fueran, sin duda, importantes, la mayoría de estas obras serían promocionadas directamente por los Obispos, ilustrados o no. Entre ellos no faltaron personalidades tan fabulosas y sobresalientes como, por ejemplo, el Cardenal Francisco Antonio de Lorenzana (1725-1804), a quien se debe desde 1772 la casi totalidad de las realizaciones del interior de la Catedral de Toledo, siendo su labor completada por el Cardenal Luis de Borbón ${ }^{6}$. Contemporáneos suyos fueron los Obispos o Arzobispos Antonio Calderón, que ocupó la sede de Burgo de Osma (Soria) entre 1764 y 1786; Claudio Sánz y Torres (1704-1779), promotor de las numerosas intervenciones en el interior de la Catedral de Almería; Rubió en el templo catedralicio de Palma de Mallorca; Manuel de Samaniego en el de Tarragona, Guillén en Burgos.

\section{A MODO DE MÉTODO}

En este artículo - tal y como ya indiqué en otras dos ocasiones al referirme, primero, a las bases metodológicas para el estudio de las transformaciones arquitectónicas de la segunda mitad del siglo XVIII en las catedrales góticas españolas ${ }^{7} y$, después, a las realizaciones llevadas a cabo en sus exteriores ${ }^{8}$ - tan sólo se intentará hipotéticamente acercarse al estado de los conocimientos actuales sobre las obras hechas en los interiores de esos templos catedralicios bajomedievales a lo largo de la llustración. Tal período suele identificarse genéricamente y de una forma convencional con el momento de auge del neoclasicismo, aun-

6 Luis Sierra Nava-Lasa, El Cardenal Lorenzana y la llustración. Madrid, Seminario Cisneros de la Fundación Universitaria Española, 1975.

José Enrique Garcia MELERo, "Bases metodológicas para el estudio de las transformaciones arquitectónicas de las catedrales góticas". Ponencia presentada en las IV Jornadas de Arte, El Arte en tiempos de Carlos III. Madrid, 29-30 de noviembre y 1-2 de diciembre de 1988. Departamento de Historia del Arte “Diego Velázquez", Centro de Estudios Históricos, CSIC, 1989, pág. 125-135.

8 José Enrique GaRcia MELERO, “Transformaciones arquitectónicas..." 
que, en verdad, no presente una indudable unidad estilistica, sino la práctica de una diversidad de lenguajes y dialectos artísticos con la pervivencia de ya viejas fórmulas barrocas y hasta rococós, soluciones barrocas clasicistas según maneras italianas y francesas, que sirven de transición a aproximaciones a los modelos de la antigüedad con la referencia obligada al código vitruviano, y a ciertos inicios del liberalismo arquitectónico romántico.

Para lograr ese acercamiento, al que se ha hecho referencia antes, se ha utilizado tanto la bibliografía actual — que ha tratado sobre algunas de estas intervenciones en particular, pero sin haberse enfrentado con la totalidad y sin relacionarlas entre sí- como determinadas fuentes literarias decimonónicas, sobre todo, las historias locales, las guias de ciudades y las monografías dedicadas a algunas de estas catedrales. Tales publicaciones aportan numerosos datos entresacados de los archivos con la consulta de documentos, algunos de ellos hoy día desaparecidos o perdidos. Son el fruto de una metodología positivista y del gusto entonces creciente hacia el gótico, lo que muchas veces llevó a esos historiadores a realizar una crítica mordaz de las "añadiduras" neoclásicas a estos edificios. No obstante, les pasaron desapercibidas varias de estas obras. No se fijaron en ellas por haberse realizado en una época relativamente cercana a la suya debido al desinterés que, casi siempre, demostraron por el momento precedente.

Además de estas fuentes literarias y bibliográficas se ha consultado el Archivo de la Real Academia de Bellas Artes de San Fernando y concretamente un legajo dedicado a las Catedrales durante el periodo 1766-1782, asi como las Actas de la Comisión de Arquitectura desde 1786 a 1828 y sus informes correspondientes. En áquel hay una serie de documentos sobre los templos catedralicios de Salamanca (1766), Pamplona (1782), Almería (1785-1791), León (1794), Segovia (1795), Lugo (1804) y Burgos (1805). Estos manuscritos aluden, por lo general, a una serie de tensiones habidas entre los distintos cabildos y la Academia al no haberse ni enviado los proyectos y alzados ni pedido permiso para realizar reformas y nuevas obras en ellas, tal y como obligaban los diversos decretos promulgados en el reinado de Carlos III y confirmados en el de su hijo y sucesor Carlos IV ${ }^{9}$.

9 Archivo de la Real Academia de Bellas Artes de San Fernando. Legajos 2-32/5 (Catedrales. 1766-1862); 1-28/1 (Comisión de Arquitectura. Informes. 1788-1797); 1-28/2 (Comisión de Arquitectura. Informes. 1798-1804); 1-28/5 (Comisión de Arquitectura. Informes. 1758-1815). 3/139 (Actas de la Sección de Arquitectura. Desde 1786 hasta 1805). 
Se es totalmente consciente de que en el presente artículo muchas veces se incurrirá en la "virtud» o en el "defecto», según sea la óptica de quien lo lea, apriorísticos de ofrecer una metodología excesivamente positivista con algunos breves ensayos formalistas y apuntes descriptivos como factores totalmente necesarios de identificación. Dada la idea previa de ofrecer aquí una visión global de las transformaciones existentes, deteniéndose en aquellas más importantes o que tengan un significado histórico especial por su incidencia en las líneas de actuación de la Academia, será preciso enunciarlas como simple referencia informativa, para que, posteriormente, se realicen otros trabajos más monográficos, completos y profundos desde el conocimiento de su existencia, que después a su vez originarán nuevas sintesis más selectivas y de un mayor contenido ideológico. También se parte de la idea del carácter casi utópico de toda referencia exhaustiva de estas obras, debido al estado actual de los conocimientos, manifiesto documental y bibliográficamente con la falta de una labor de profundización en los diferentes archivos catedralicios para extraer nuevos datos y confirmar muchos de los publicados.

Los análisis y descripciones de las obras realizadas durante la segunda mitad del siglo XVIII han sido agrupados en este artículo de una forma totalmente convencional por el nombre de cada templo catedralicio. A su vez se ha procurado ordenarles, siempre que ello era posible, por la fecha del inicio de las construcciones, poniéndo delante las más antiguas. El sistema empleado permite ofrecer una visión global de las distintas transformaciones llevadas a cabo en cada una de las catedrales y sin interrumpir, además, la perspectiva espacial de un mismo escenario geográfico. Para intentar cubrir el posible defecto de la falta de una linealidad histórica se ofrece a continuación un panorama general de las realizaciones, tanto en los exteriores como en los interiores de los templos, y en función de los distintos reinados de Fernando VI, Carlos III y Carlos IV. El estudio cronológico de las diferentes obras dentro de cada una de estas etapas aporta un juicio de valor comparativo entre ellas y, asímismo, el análisis de una cierta evolución en el uso de los lenguajes artísticos. Ofrece, también, un cambio importante en la consideración del estilo gótico durante las décadas finales de la centuria, cambio ideológico que incide en la práctica arquitectónica a la hora de enfrentarse con las nuevas realizaciones en esas catedrales. Asi, el epígrafe siguiente sirve de conclusión a este estudio, aunque no se halle al final del mismo, y las transformaciones reseñadas después cumplen la función de catálogo documentado, analítico y descriptivo, en las que se basa. 


\section{PANORAMA GENERAL DE LAS REALIZACIONES}

\section{Reinado de Fernando VI (1746-1759)}

Durante el reinado de Fernando VI no se hicieron muchas obras tanto en los exteriores como en los interiores de las catedrales góticas españolas. Ventura Rodríguez fue entonces el àrquitecto más activo, pues a él se deben los diseños de 1752 para la capilla de San Julián y el altar mayor de la Catedral de Cuenca, que fueron inaugurados en 1760 , ya en tiempos de Carlos III, y el proyecto irrealizado para la fachada principal del templo catedralicio de Burgo de Osma (Soria). En uno y otro caso utilizó un lenguaje estilístico transicional barroco clasicista; pero tratado con una mentalidad todavía totalmente barroca, pues el Transparente parece en este sentido una réplica del de Toledo, aunque se usaran unas formas atenuadas cercanas en cierto modo a fórmulas más clásicas que las empleadas en la España de ese momento. En la fachada principal de la Catedral de Burgo de Osma (figs. 1 y 2) unió eclécticamente el barroco clasicista italiano con la referencia a la Catedral de Valladolid. Aún hay una clara concepción escenográfica y de ocultación de la realidad gótica preexistente, la propia de la primera mitad del siglo XVIII en la misma línea que las fachadas principales de las catedrales de Valencia (1703) (fig. 3) de Conrado Rodulfo y de Murcia (1731) (fig. 4) de Jaime Bort ${ }^{10}$.

Un fenómeno natural, el famoso terrremoto de Lisboa del 1 de noviembre de 1755, repercutió, por desgracia, en el panorama general de las obras realizadas entonces, deteriorando los exteriores de algunas de estas Catedrales, aunque resultaran mucho más afectadas - lo cual parece bastante significativo- las partes no góticas, persistentes de otros períodos históricos o añadidas posteriormente. Se cuarteó la torre de la

10 Fernando Chueca Goitia, «La arquitectura religiosa en el siglo XVIII y las obras del Burgo de Osma". Archivo Español de Arte, tomo XXII, núm 88. Madrid, Instituto Diego Velázquez del CSIC, 1949, pág. 287-315. El Arquitecto Ventura Rodriguez (1717-1785). Madrid, Museo Municipal, noviembre de 1983, proyecto en pág. 11.- Estudios sobre Ventura Rodriguez. Madrid, Real Academia de Bellas Artes de San Fernando, 1985.- Pedro Monleon Gavilanes, La arquitectura de Juan de Villanueva. El proceso del proyecto. (Madrid) Servicio de Publicaciones del Colegio Oficial de Arquitectos de Madrid (1988), pág. 326-327. 
Catedral nueva de Salamanca ${ }^{11}$, afectó a la antigua, de Santa María, de la románica de Ciudad Rodrigo y agrietó a la Giralda ${ }^{12}$. Todo ello ocupó durante algún tiempo a los maestros catedralicios y hasta provocaría a veces debates y duras polémicas entre los arquitectos al plantearse el modo más acertado de intervenir a la hora de reconstruirlas, tal y como ocurrió en la ciudad del río Tormes.

No se plantearon en este momento grandes prejuicios historicistas sobre la manera más adecuada de actuar en estos templos góticos, pues persistieron las fórmulas que se estaban empleando antes con su mentalidad barroca. Tampoco parece que se hubieran establecido aún las bases ideológicas para el discutido y discutible conflicto entre el gótico y las formas clasicistas y dictado categóricamente la superioridad de éstas sobre áquellas. Simplemente se consideraba a las catedrales bajomediavales como edificios construidos en otras épocas, que cumplían una adecuada función litúrgica, susceptibles de mejoras y necesitados de una labor de conservación contínua debido, sobre todo, a sus enormes dimensiones y antigüedad. Además, durante el reinado de Fernando VI hubo muchas más obras en los exteriores de estos templos que en sus interiores.

\section{Reinado de Carlos III (1759-1788)}

En el reinado de Carlos III, que cronológicamente fue bastante más extenso que el de Fernando VI, su hermano y antecesor, se realizaron la

11 Fernando Chueca Goitia, La Catedral Nueva de Salamanca. Historia documentada de su construcción. Preámbulo de D. Manuel Gómez Moreno. Salamanca, Universidad, 1951. (Filosofía y Letras, tomo IV, núm 3. Acta Salmanticensia).- Elias Tormo: Salamanca: las catedrales. (Sobre estudios inéditos de D. Manuel Gómez Moreno). Madrid, Patrimonio Nacional de Turismo (s.a.), pág. 75-76.- George KuBLER, Arquitectura de los siglos XVII y xvili. Madrid, Ed. Plus Ultra, 1957, pág. 182.- José CAMON AZNAR, "Sobre la torre de la Catedral nueva de Salamanca». Archivo Español de Arte. tomo. XIV, 1940-1941, pág. 473.- Alfonso Rodríguez G. De Ceballos, "La torre de la Catedral Nueva de Salamanca". Boletín del Seminario del Arte y Arqueología, tomo XLIV. Valladolid, 1978, pág. 246-255.Antonio PONZ ya se refirió a la acción de este terremoto en la torre de la Catedral nueva de Salamanca en su Viage, tomo II, carta sexta, pág. 185-186.

${ }_{12}$ La Catedral de Sevilla, Prólogo de Fernando Chueca Goitia... Sevilla, Ediciones Guadalquivir (1984). Sobre los efectos del terremoto de Lisboa en la Giralda puede verse la colaboración de Alfonso JIMÉNEZ MARTín sobre "El patio de los naranjos y la Giralda", pág. 83-132, véase pág. 125. Una fuente: Relación verídica del horroroso terremoto, que acaeció en.. Sevilla, el primero de noviembre de 1755... En Sevilla, en la Imprenta Real de la Viuda de D. Diego López de Haro (s.a.: 1775?). También: Francisco AguILAR PiñaL, Historia de Sevilla. Siglo xvIII. 2. ${ }^{a}$ ed. Sevilla (Universidad, 1982), pág. 84-85. 
mayoría de las principales obras efectuadas durante toda la segunda mitad el siglo XVIII en las catedrales góticas españolas. En realidad, tal y como se apuntó antes, no hubo un programa unitario, ni formal ni de intenciones, sino comportamientos muy difíciles de codificar aquí a un nivel general, que dependieron, sobre todo, de las necesidades especificas de cada catedral, de las ideas de sus obispos y cabildos respectivos $y$ de las diferentes concepciones artísticas de los arquitectos, que intervinieron.

No obstante, y como es obvio, se reflejó fielmente en este campo tan peculiar todo lo que ocurría a un nivel global en la práctica arquitectónica española de este período de los inicios del eclecticismo historicista clasicista y de la recuperación a un nivel historiográfico de los medievalismos, etapa quizás mal llamada neoclásica - término que se deberá revisar- con todas sus dudas y contradicciones. Asi, desde 1777, fecha de la célebre carta circular del rey a las jerarquías eclesiásticas, y, sobre todo, desde el comienzo de la actuación de la Comisión de Arquitectura en 1786, ya en las postrimerías del reinado de Carlos III, se establecieron las bases efectivas para realizar un control mucho mayor sobre estas intervenciones al obligar a los arquitectos a enviar sus proyectos a la Academia de San Fernando para su aprobación.

Durante los casi veinte años, que mediaron entre la entronización de Carlos III en 1759 y la promulgación de la Real Cédula de 1777, se realizaron importantes obras en la mayoría de nuestras catedrales de transición al gótico, de plenitud y tardogóticas. Es, sin duda, un momento clave en la arquitectura española de la segunda mitad del siglo XVIII; instante de tensiones en el seno mismo de la Academia, que se planteó la solución más adecuada para llegar al clasicismo. Ahora pesará, sin duda, la sombra del libro de Vitruvio, cuyo Compendio de Perrault, un arquitecto francés barroco clasicista, es traducido por Castañeda en $1761^{13}$.

La diversidad de criterios metodológicos, presente en tales polémicas, se materializó casi con fidelidad total en estas obras a través del empleo de numerosos dialectos del clasicismo, teñidos de suaves tintes barrocos bajo la doble opción francesa e italiana. $Y$ así se manifiesta en

13 Vitruvio, Compendio de los diez libros de arquitectura de Vitruvio. Escrito en francés por Claudio Perrault, de la Real Academia de las Ciencias de París. Traducido al castellano por don Joseph de Castañeda, teniente director de arquitectura de la Real Academia de San Fernando. En Madrid, en la Imprenta de don Gabriel Ramírez, impresor de la Academia, año de MDCCLXI. Es importante el estudio introductorio de Joaquin BERCHEZ GOMEZ, "La difusión de Vitruvio en el marco del neoclasicismo español», a la edición facsimil publicada en Murcia en 1981. 
los grandes programas catedralicios del período, en donde la sombra del cánon vitruviano parece justificar en este momento una mayor libertad a la hora de enfrentarse con la presencia gótica en la Catedral y hasta deducirse la superioridad de áquel sistema sobre éste último, salido de una de las grandes fosas cíclicas de la Historia.

Así pues, las obras realizadas en las catedrales góticas españolas desde 1759 a 1777 fueron tan numerosas como diversas. Habia, sin duda, una doble heterogeneidad formal entre las promovidas por los distintos obispos, arzobispos y cabildos catedralicios y las patrocinadas por la Corona. Estas se hallaban a su vez bajo la sombra ineludible del debate en la Academia. Tal disparidad estilística dependia de la posesión o de la falta de una formación académica; del conocimiento o ignorancia de 10 que los arquitectos franceses e italianos hacían en España, y de lo que los españoles, instruidos con ellos en la construcción del Palacio Real, proyectaban o polemizaban entre sí en Madrid; de los viajes a otros países, sobre todo a Roma y Francia; de la información a cerca de lo que entonces se construía en el extranjero, y también de la personalidad peculiar de cada uno de ellos. Así, mientras que en la sacristía de la Catedral de Burgos (1759-1767) los maestros locales Fray Antonio de San José Pontones y Fray José de San Juan de la Cruz, y José Prat entre 1760 y 1775 en la capilla de Santa Tecla de la Catedral de Tarragona siguieron empleando lenguajes ya bastante trasnochados, basados en fórmulas abigarradas casi rococós, el joven Juan de Villanueva utilizó en la sacritía (1770) y en la capilla del venerable Palafox (1772) un repertorio clásico tan amplio como entonces novedoso con claras referencias a Vignola en la primera, pero sin olvidar todavía el influjo de Ventura Rodríguez, y a Palladio y al Panteón de Roma en esta última.

Las tensiones entre los lenguajes clasicista y el gótico, y entre las fórmulas ahora novedosas, que entonces se deseaban implantar, y las, en cierto modo, ya trasnochadas, tuvieron como escenarios principales y respectivamente a las Catedrales de Toledo y de Segovia. Pero en estos casos en concreto no se trataba de un enfrentamiento entre las distintas concepciones arquitectónicas a la hora de aproximarse a lo clásico de unos arquitectos de la Corte, sino de éstos con los respectivos cabildos catedralicios más o menos, y discutiblemente, tradicionalistas. Así ocurrió con el proyecto irrealizado de Ventura Rodríguez para la fachada principal de la Catedral Primada (fig. 5), rechazado en 1773 por los canónigos toledanos, aunque aquí la idea de una nueva imagen para este templo gótico, que ocultara otra realidad del viejo pasado, parece hallarse dentro de unas fórmulas barrocas en cuanto a su intención y a pesar de la 
pretendida falta de su pureza goticista, debido a la actuación del siglo XVII en esta fachada ${ }^{14}$. Lo novedoso está en la idea de restauración aportada precisamente por ese cabildo y conservando las distintas huellas del pasado. En el trascoro de la Catedral de Segovia se enfrentaron ya diez años después y promulgada la Cédula de 1777, dos concepciones espaciales y estilísticas diferentes representadas por Joaquín Demandre y Juan de Villanueva, partidarios de crear o un espacio cerrado u de otro abierto al adosarle al muro del trascoro y del predominio o de la verticalidad o de 10 horizontal ${ }^{15}$.

Otras dos obras muy significativas, además de las diversas actuaciones barrocas-clasicistas en la Catedral de Almería entre 1773 y 1777 de Valdez con la supervisión, al parecer, de Ventura Rodríguez - mesa de altar, tabernáculo y trascoro-, destacan en este momento importante: la realización del altar mayor de la Catedral de Segovia en 1768 y del inicio de la remodelación del interior de toda una catedral gótica, como es la de Valencia. En aquella se crea ahora un prototipo imitable por la depuración de sus líneas clasicistas y la nobleza de los materiales empleados. En esta última transformación la fiebre por lo clásico de una mentalidad tan retorcida, como la que aqui refleja Gilabert, sueña con ocultar, con dar otra imagen distinta en el uso del verdadero estilo, la inmensidad del interior de una catedral gótica. Todo ello parece la realización de una utopía, el desbordamiento incontrolado de un academicismo tal vez mal interpretado, y también la proyección de una pesadilla goyesca, y un atentado contra quienes entonces ya promovian el historicismo.

En el periodo comprendido entre 1777 y 1788, año del fallecimiento de Carlos III, se concluyeron la mayoría de las obras proyectadas e ini-

14 Sobre el proyecto diseñado por Ventura Rodríguez para la fachada principal de la Catedral de Toledo véase, Fernando MARiAS, "Ventura Rodríguez en Toledo (1772-1785)", Estudios sobre Ventura Rodriguez. Madrid, Real Academia de Bellas Artes de San Fernando, 1985, pág. 61-69. Marías localiza en el Archivo de la Catedral de Toledo, Actas Capitulares, 80,6 de marzo de 1777 , pág. $228 \mathrm{r}^{\circ}$, el rechazo del proyecto de este arquitecto. Sobre las reformas realizadas en las distintas fachadas de esta Catedral, pág. 75-79. Véanse también los datos y juicios aportados sobre ellas por Sixto Ramon PARRo, Toledo en la mano o descripción histórica-artística de la magnifica catedral y de sus demás célebres monumentos... Toledo, Imp. y Libr. de Severiano López Fando, 1857, vol. 1, pág. 223230, 295-300 y 467 y ss. Asímismo en Quadrado, Recuerdos y bellezas de España, volúmen dedicado a Castilla la Nueva, pág. 355-356, 338-339 y 341.

15 Antonio Ruiz Hernando, "Ventura Rodriguez y Juan de Villanueva en el trascoro de la Catedral de Segovia», Estudios sobre Ventura Rodriguez. Madrid 1985, pág. 199-242. Se basa en la documentación del Archivo de la Catedral de Segovia (Libro de Acuerdos, 1776-1783, 1784-1788 y 1789-1794, G. 134 y G. 66 y Libro de Data de 1773) y en el Archivo de Palacio Real de Madrid (legajo 40. San Idelfonso). Algunos de estos manuscritos se publican en el texto del artículo y en las notas bibliográficas. 
ciadas durante la etapa anterior, y se construirian también varios retablos, como el de la Capilla de San Ildefonso de la Catedral de Toledo por Ventura Rodríguez, con el uso de un lenguaje arquitectónico más depurado y el empleo de ricos materiales, tal y como se indicaba en esa Real Cédula y era el deseo de Antonio Ponz, el entonces secretario de la Real Academia de Bellas Artes de San Fernando. Asímismo, en 1778 se entregaron las obras de restauración de la fachada del Perdón de este templo catedralicio, advirtiéndose un cierto respeto historicista hacia lo construido anteriormente en ella, casi una restauración (fig. 6).

Sin embargo, la realización, quizás, más significativa fue el cumplimiento de una idea largamente pensada y esperada por Ventura Rodríguez: el proyecto, ahora hecho realidad, de construir una nueva fachada en una vieja catedral bajomedieval. Los planos de 1783 para el frente principal del templo catedralicio de Pamplona (figs. 7 y 8 ) resultan la materialización de los frustrados de Burgo de Osma de 1755 y de Toledo de 1773; pero elaborados todos ellos de un modo totalmente progresivo, pues sus formas se iban, o intentaban, adecuando a la evolución experimentada por el maestro y por la arquitectura del Reino. Dió con esta fachada una nueva imagen a la ciudad navarra, ocultando en gran medida la antigua referencia medieval de la urbe; mas sin que el exterior clasicista se interfiriera con el interior del templo, que se respetó. Así, si las formas resultaban ahora mucho más clásicas, la intención seguía siendo todavía barroca. Se deseaba crear una escenografía urbanística más moderna, tratada casi como una arquitectura fingida, en el uso del estilo "verdadero", y también de ocultar una realidad histórica aún totalmente incomprendida ${ }^{16}$.

16 José Goñ Gaztambide, "La fachada neoclásica de la catedral de Pamplona", Príncipe de Viana, 1970, núms. 118-119, t. XXXI, pág. 5-64. También en José Yarnoz Larrosa, Ventura Rodríguez y su obra en Navarra, por... y Modesto López Otero. Madrid, Real Academia de Bellas Artes de San Fernandu, 1944, en donde recoge el informe de Manuel Martín Rodriguez sobre la fachada de la Catedral de Pamplona emitido en 1791. Para Fernando CHUECA GoITIA, en "Ventura Rodriguez y la escuela barroca romana", Archivo Español de Arte, núm. 52, Madrid 1942, pág. 185-210, publicado también en el Catálogo de la exposición El Arquitecto D. Ventura Rodriguez (1717-1785), Madrid, Concejalía de Cultura del Ayuntamiento, 1983, pág. 11-31: (..) "La fachada de la Catedral de Pamplona, por ejemplo, a pesar de su frialdad y sequedad, es en el fondo una obra barroca esterilizada. Su esquema procede claramente de la de Maderna, para San Pedro, y sus torres, aunque graciosas, son netamente barrocas"(...) pág. 22. También Pedro Navascues, La formación de la arquitectura clásica. En "La época de la llustración", pág. 674, tomo XXXI de la Historia de España fundada por Ramón Menéndez Pidal. Madrid, Espasa Calpe, 1987. 


\section{Reinado de Carlos IV (1788-1808)}

Durante el reinado de Carlos IV se continuó el proceso de transformación de la vieja catedral gótica española, heredándose todos los instrumentos de centralización y de control del arte, creados en la época de su padre. La Academia madrileña contará ahora con una nueva institución para llevar a cabo de un modo más efectivo la supervisión de cuantos proyectos se diseñen en el Reino a través de la Comisión de Arquitectura fundada en 1786 y dirigida por Pedro José Arnal bajo las secretarías sucesivas de José Moreno, Luis Paret y Silvestre Pérez. A ello hay que añadir una disposición, la Circular del 28 de febrero de 1787, que afectaba directamente a las obras realizadas en las catedrales, pues se disponia que los arquitectos o maestros mayores de las capitales y cabildos eclesiásticos fueran, precisamente, académicos de mérito de la de San Fernando o de San Carlos, para el Reino de Valencia. Pero también se contará con una edición crítica y actualizada de De Architectura de Vitruvio, realizada en 1787 por el valenciano, obsesivo y constante, José Ortiz y Sanz ${ }^{17}$.

Esta versión, trabajosamente elaborada en España y en Roma, ofrecerá una alternativa más clásica frente a la vía barroca clasicista abierta con la traducción del Compendio de Perrault por Castañeda en 1761 y servirá a la generación de arquitectos nacidos en los años treinta. No obstante, al poco de aparecer tal catecismo ecléctico del antiguo clasicismo, se reeditaron diversos textos del moderno clasicismo renacentista y del nuevo de la llustración, que en lugar de unificar y hacer más universal el lenguaje de la época - vieja aspiración en cierta forma fracasada- le diversificó en numerosos dialectos. La multiplicidad de opciones apuntó su carácter utópico y abrió, junto al creciente histori-

17 Marco Vitruvio Polion, Los diez libros de Architectura de... Traducidos del latín y comentados por Don Joseph Ortiz y Sanz, Presbitero... En Madrid, en la Imprenta Real, año de 1787. Sobre Ortíz y Sanz y su traducción del Vitruvio: Carlos SAmBricio, "La teoría arquitectónica en José Ortiz y Sanz "el vitruviano". Revista de Ideas Estéticas. 1975, núm. 131, pág. 259-286. Joaquín BERCHEz GOMEz, “J. F. Ortiz y Sanz: correspondencia mantenida desde Roma a propósito de su traducción de Vitruvio (1780-1782)". Archivo de Arte valenciano, año LXIII. Valencia 1981, pág. 62-70. En la edición facsimil de Madrid, Akal, 1987 se incluye un prólogo de Delfín RODRíguez Rulz sobre “José Ortiz y Sanz: atención y pulso de un traductor". Una visión de conjunto sobre las diversas ediciones españolas de este tratado y su significado en el contexto de cada época en José Enrique Garcia MELERO, "Las ediciones españolas “De Architectura” de Vitruvio. Fragmentos, núms. 8-9. Madrid, Ministerio de Cultura, 1986, pág. 102-131. 
cismo de diverso sino propiciado por la labor historiográfica, la puerta de la libertad y de la heterogeneidad, tan caracteristica de la práctica arquitectónica «romántica».

La mayoría de las realizaciones de este reinado en las catedrales góticas españolas se hallaban bajo el estricto control burocrático de esa Comisión de Arquitectura, que vigiló cuidadosamente su calidad y la pureza clásica. En las actas redactadas entre 1786 y 1805 hay contínuos informes y resoluciones que afectaron a estos templos, autorizándose 0 desautorizándose las diversas obras, y también se reflejan numerosas denuncias de aquellos proyectos que no habian pasado por el control de la activa Academia. Entonces parecía pensarse que todo aquello, que se realizaba en la catedral, habría de servir siempre de ejemplo a las diversas construcciones de la época, dada la importancia simbólica de tales edificios.

Sin embargo, las obras que se emprendieron durante este reinado no tuvieron, salvo algunas dignas excepciones como el claustro de la Catedral de Almería (1795) de Munar y la puerta Llana de la de Toledo (1800) (fig. 9) del muy clásico Ignacio Haan ${ }^{18}$, la importancia y el significado de lo hecho durante el de Carlos III. Además, entre 1793 y 1796 parece reflejarse en ellas la gran depresión económica, que trajeron consigo la guerra con Francia, las malas cosechas y el alza de los precios y de los salarios; en una sóla palabra, la inflación. No obstante, muy pocos años antes se habían acometido obras tan caras como la renovación de los deteriorados enlosados de las Catedrales de Burgos, bajo la dirección de Fernando González de Lara en 1789, y de Sevilla, concluida en 1793. Pero lo que entonces se hizo no pasó, con la prudencia que exige toda afirmación, de ser de una importancia menor y tanto desde el punto de vista económico como artístico.

No obstante, este reinado es del mayor interés dentro del campo específico de la historia de la historiografía española y aún de la evolución estética, porque durante estos años se establecieron las bases ideológicas para llegar a toda una teoría de la conservación de las catedrales góticas, fruto de la labor historicista muy importante realizada por destacados eruditos ilustrados como Ponz, Jovellanos, Llaguno, Bosarte,

18 M. LORENTE JUNOUERA, «Don Ignacio Haan». Revisța Nacional de Arquitectura, núm. 81, Madrid 1949, pág. 362. Amplia referencia a esta puerta Llana de la Catedral de Toledo en Sixto Ramón PARRO, Toledo en la mano, obra citada en nota 14, vol. 1, pág. 280. Fernando ChUECA Goitia, "Los arquitectos neoclásicos y sus ideas estéticas". Revista de Ideas Estéticas, núm. 2, abril-junio, 1943, artículo también incluido en su Varia neoclásica, Madrid, Instituto de España, 1983, pág. 183. 
Ceán... Sus estudios propiciaron en gran medida la ya conocida y divulgada dicotomía entre el clasicismo y el gótico, racionalizándose la superioridad de aquellas formas sobre éstas; pero sintiéndose de un modo contradictorio cierta admiración por ellas tanto a un nivel poético como, a veces, también en el técnico, al reconocerse la fortaleza de estas construcciones. Se gestaron, además, en tal "prerromanticismo" muchas de las notas peculiares de la poética romántica ${ }^{19}$.

\section{Hacia la formulación de una teoría sobre el modo de intervenir en las catedrales góticas españolas}

El historicismo, que reconcilió a los eruditos, la avanzadilla ideológica del país en este momento de tránsito entre los siglos XVIII y XIX, con el arte gótico, aun reconociendose la superioridad del clasicismo, geperaria toda una teoría sobre la forma de actuar en las catedrales góticas. La búsqueda histórica de la justificación del clasicismo con toda su carga de utopía derivó en la apreciación de otros estilos entonces considerados heterodoxos. Isidoro Bosarte, secretario de la Academia de San Fernando desde 1792, fue el personaje clave en la redacción de estos principios, que expuso, muy entre líneas, en dos de sus publicaciones: en la Disertación sobre el estilo que llaman gótico en las obras de arquitectura $(1798)^{20}$ y en su Viage artístico a varios pueblos de España $(1804)^{21}$.

19 Sobre la valoración de los estilos mediavales cristianos durante la segunda mitad del siglo XVIII pueden verse: José Maria AZCARATE, "Valoración del gótico en la estética del siglo XVIII". En El Padre Feijóo y su siglo. Oviedo, 1966, pág, 525-549 (Cuadernos de la Catedra Feijóo, núm 18). - Ignacio HenaRes Cuellar, La teoría de las artes plásticas en España en la segunda mitad del siglo XVIII. Granada, Departamento de Historia del Arte de la Universidad de Granada, 1977.- José Enrique GaRCia MELERO, “La visión del románico en la historiografía española del "neoclasicismo romántico»". Espacio, tiempo y forma, núm 2. Madrid, Facultad de Geografía e Historia de la UNED, 1988, pág. 139-186.

${ }_{20}$ Isidoro BOSARTE, Discurso sobre la restauración de las Bellas Artes en España. Disertación sobre el estilo que llaman gótico en las obras de arquitectura. Madrid, Imp. de la viuda de Ibarra, 1798. En el "Gabinete de lectura española, o Colección de muchos papeles curiosos de Escritos antiguos y modernos de la Nación", núm. III.

${ }^{21}$ ISIDORO BOSARTE, Viage artistico a varios pueblos de España, con el juicio de las obras de las Tres Nobles Artes, que en ellos existen, y épocas a que pertenecen. Madrid, Imp. Real, 1804. Numerosas noticias sobre Bosarte en el prólogo de Alfonso E. Pérez Sánchez a la edición facsimil de Madrid, Turner, 1978. Documentación sobre Bosarte en la Real Academia de Belias Artes de San Fernando: 1-16/10, 81-7/4, 61-4/5 y 62-2/5. El manuscrito del viaje en 316-1/3. 
La valía indudable de Bosarte en este campo específico del encuentro entre la erudición historicista y la estética no ha sido aún hoy totalmente reconocida, considerándosele tan sólo cual una personalidad muy de segundo orden por nuestra historiografía actual al ser comparado con los gigantescos Ponz, Jovellanos, Llaguno y Ceán. Pero es hora ya de ver su aportación como una de las figuras más representativas, primero, de esa dicotomía entre el clasicismo y el goticismo y, después, de la valoración positiva del gótico. Bosarte es uno de los abanderados de esa contradicción entre el racionalismo, quizás ahora cuestionado, y el sentimentalismo, que se dibuja en el panorama general de la época, de los años finales del siglo de la llustración.

Bosarte tuvo que luchar contra la sombra de Ponz, su antecesor en esa Secretaría de la Academia, y a quien intentó emular repetidas veces. Así, si éste formuló la censura del barroco frente al clasicismo, áquel, al parecer, quiso ser en un principio el principal crítico del gótico para confirmar, precisamente, el estilo antiguo. De este modo reprobó a esa tendencia bajomedieval por confundir la idea de la "grandiosidad" con la de «magnitud», por sus «menudencias», «inutilidad», «desproporción», falta de "Eurritmia", de "simetria», de "decoro» y de «equilibrio» ${ }^{22}$. Sin embargo, fue capaz de darse cuenta de la poca viabilidad de este proyecto y evolucionó hacia unas directrices típicamente "prerrománticas", que latían en el ambiente.

En su disertación sobre el gótico Bosarte se planteó un problema básico en este momento: "Si quando hay que añadir obra à un edificio Gótico se ha de seguir de conformidad en el estilo, ò se ha de hacer añadidura según el buen gusto" ${ }^{23}$. Lo problemático de tal pregunta se halla en la oposición entre lo clásico y el gótico, entre el credo clasicista, que le hizo estar convencido de la superioridad de ese sistema artístico y este estilo "caprichoso" y de "antojos inciertos" ${ }^{24}$. Pero la última palabra en la cuestión propuesta la tuvo el historicismo, el papel de testimonio de una época que la tendencia bajomedieval, aún siendo aberrante para una mentalidad como la suya, poseía para lograr el conocimiento racional de un período histórico.

Bosarte enumeró siete principios para contestar a la pregunta formulada. Los cuatro primeros son una defensa auténtica del clasicismo frente al gótico, que criticará con cierta dureza, y un elogio de los ures-

\footnotetext{
22 Bosarte, Disertación..., pág. 29-30.

23 lbídem, pág. 50.

24 lbídem, pág. 51.
} 
tauradores de las Artes", quienes "añadian y exornaban las obras viejas del estilo antiquado según las máximas de los órdenes antiguos de Arquitectura, y los adornos del buen gusto". Basó, así, la superioridad del estilo clásico sobre esta arquitectura "antiquada" en "la elegancia y magestad" de los tres órdenes de la griega, en su antigüedad por ser «muchos centenares de años anteriores al estilo gótico, que ha pretendido iniquamente tiranizarlos y obscurecerlos, y lo ha logrado por espacio de ocho siglos" y porque desde el siglo XVI hasta su época «han trabajado los hombres de talento (...), y siguen trabajando con todas las luces de la crítica", mientras que "por el estilo gótico nadie se interesa, y todos lo han dexado". Ello le permitió indicar en el primer enunciado que "los principios seguros del Arte, y las máximas del buen gusto debén mantenerse una vez hallados, y no se debén posponer à caprichos, ù antojos inciertos" ${ }^{25}$.

Las tres máximas siguientes nos interesan aquí de una forma especial, pues mantienen la idea de la superioridad del sistema clásico sobre el gótico, todo lo cual promovió la opinión de que las realizaciones clasicistas en edificios de este estilo bajomedieval no les perjudica, sino que por el contrario, les ennoblece, aceptándose, así, la intromisión de éste en áquel: «5. Las añadiduras según el buen gusto greco-romano à las obras góticas no pueden perjudicarlas, ni desgraciarlas, por quanto son mejores que ellas. 6. En añadiendo nuevas obras al Gótico, irá renaciendo el edificio según el buen arte. 7. Por la imitación del estilo gótico no hay más razón que la conformidad con una cosa mala. Y siendo esta razón única y endeble, deben prevalecer seis fuertes que hemos dado contra una flaca» ${ }^{26}$.

Isidoro Bosarte trató a continuación en su libro sobre el gótico acerca de otro aspecto que afecta, indudablemente, a nuestro tema: "si las obras disconformes de Arquitectura cargadas de adornos estrafalarios se han de raer, ò picar, y quitarles aquella cargazón..." En este sentido se mostraría como un auténtico historicista, pues se manifestó contrario a ellos, porque la «Historia de las Artes debe quedar dotada, y tanto lo bueno como lo malo pertenece à la Historia del Arte, cada cosa para su fin. Un edificio, ù otra obra del Arte ya hecha tiene un cierto derecho à existir. Las correcciones y las enmiendas de otras escuelas no le pertenecen. Ni las pinturas se han de retocar, como quiere el vulgo; ni las arquitecturas se han de alterar, como zelosamente quieren los profesores 
eruditos". No obstante, exceptuó de esta regla de conservación de lo antiguo aquello que obliga "el caso de necesidad" ${ }^{27}$.

Las afirmaciones, que Bosarte hiciera en su famosa disertación, se confirmaron y pulieron seis años más tarde en su Viage, modesta réplica del de Ponz. En él volvería a insistir sobre este tema con motivo de la descripción de la catedral de Burgos y del despojo de los adornos primitivos de las puertas de la fachada principal (figs. 10, 11 y 12). En base a ejemplos vistos en sus viajes por Europa al acompañar al conde de Aguilar entre 1778 y 1786 en sus embajadas en Turin y en Viena, y a las actuaciones de la época en las continuaciones de las catedrales de Milán y de Strasburgo, se muestra partidario de proseguir las obras viejas en sus estilos primitivos. En este texto se prescinde de toda crítica al gótico y se insinúa ya con toda claridad que las construcciones en el nuevo estilo clásico deberian hacerse en determinados espacios arquitectónicos, en aquellos que no se interfieren con el de los de su primitiva construcción, en “cuerpos aislados existentes por si»" ${ }^{28}$.

De lo dicho hasta aqui por Bosarte se pueden deducir varios principios, que ahora se entresacan de ese segundo texto: "Los adornos de estilo gótico no deben picarse ni raerse, pues con semejante operación se defrauda à la historia del arte de sus testimonios auténticos, que son la existencia misma del cuerpo de sus obras. Aun en las continuaciones, suplementos è instauraciones de obras antiguas es menester madurar el dictámen, y no precipitar el juicio para resolver el partido que se ha de tomar por más conveniente". A continuación resume sus opiniones con las palabras siguientes: "En suma, la regla sana que en los casos dudosos de continuación y reparación de obras considerables puede tomarse es esta: La obra vieja se debe continuar según su estilo. La obra nueva subsistente por sí no está sujeta al estilo antiguo. La mezcla y confusión de estilos es intolerable, y ninguna obra vieja debe picarse ni acomodarse à otro estilo opuesto" ${ }^{29}$. Asi pues, puede deducirse de la afirmación contenida en el último párrafo una contradicción, o tal vez, con más exactitud, un cambio evolutivo en el pensamiento de Bosarte, quien seis años después parece haberse vuelto más tolerable con el estilo gótico. Se insinúa en su hasta entonces intransigente mentalidad clasicista una mayor condescendencia y cierta afición por este arte bajomedieval. Se halla ya dentro de lo que, acaso con alguna arbitrariedad

27 Ibidem, pág. 52-53

28 Bosarte, Viage artístico, ..., pág. 259.

29 Ibidem, pág. 260 . 
lingüistica-pedagógica repetidas veces admitida, podriamos denominar una ideología "clásico-romántica".

Si bien es verdad que en las publicaciones de Bosarte no puede resumirse "ex-cátedra" todo el pensamiento de la Academia en este momento de tránsito entre las dos centurias -ningún fenómeno cultural debe codificarse a base de voces aisladas - sobre este tema de las intervenciones arquitectónicas en los edificios góticos, pues, sin duda, hubo otros ecos de actuación más práctica, menos teóricas e historiográficas, que se verán a continuación, también es cierto que sus juicios sintetizan una de las opciones más significativas de la época y, además, pública y no precisamente de carácter retrógrado. Tal afirmación parece confirmarse en el hecho mismo de ser entonces el secretario de la Academia de San Fernando, de atreverse a publicar sus ideas sobre el particular en sus obras y de conocer, además, importantes intervenciones en algunas catedrales europeas como las de Milán y Strasburgo, ciudades que visitó durante sus viajes. Por lo tanto, no sería demasiado osado el decir aqui que en las publicaciones de Bosarte existe la posibilidad de ver literariamente materializado el resumen ideológico de muchas de las actuaciones de los arquitectos españoles durante la segunda mitad del siglo XVIII.

Las ideas expresadas por Bosarte en ambas publicaciones de 1789 y 1804 proporcionan una noción bastante clara y contundente - aún dentro de esa misma contradicción o evolución experimentada, a la que antes se hizo referencia- de la toma de conciencia de la existencia de un problema: el de la forma de actuar en las catedrales, en general, y en las góticas, en particular. Y la voz del secretario de la Academia era tan sólo el eco de lo que ocurría en el seno de esta entidad y especialmente en su Comisión de Arquitectura, que hubo de velar por la conservación de la pureza de estos templos frente a las iniciativas de nuevas obras tomadas por Obispos y Cabildos al margen, muchas veces, de sus disposiciones y hechas, o en vías de realización, sin enviar antes los proyectos y, por lo tanto, careciendo de todo permiso. En la Academia había penetrado una nueva vía abierta por el historicismo de signo diverso, ahora bajo la secretaría de Bosarte, y con ella se puede observar ya una manera diferente de ver y de considerar al gótico y una política también novedosa sobre la conservación de la catedral. Pero esta línea de actuación parecía no ser comprendida ni por la mayoría del estamento eclesiástico ni por algunos arquitectos, quienes anteponían necesidades y soluciones prácticas a ese historicismo. 
Algunos canónigos, conocedores de tales disposiciones y con cierta formación académica, denunciarian tales abusos, tratando al mismo tiempo de que se construyera, por una parte, siguiendo el buen gusto y respetár.dose, por la otra, los estilos existentes, dualismo que generaría ciertas tensiones. Los conflictos son entonces bastantes más frecuentes y testifican al mismo tiempo sobre una gran actividad en la Comisión de Arquitectura y, también, acerca de un cierto fracaso al ser incapaz de controlar las diversas obras de una manera realmente efectiva. Así ocurrió en la fachada de Santa María de la Catedral de Burgos, cuyas obras de González de Lara fueron suspendidas en 1790 por ser discordantes con el gótico ${ }^{30}$, o en la denuncia de 1794 del canónigo Joaquín Herrera Lorenzana ante el proyecto de cerrar el atrio de la de León con una verja según el diseño de Fernando Sánchez Pentejo ${ }^{31}$, o en las controversias de 1795 entre la Academia y el cabildo de la segoviana, que la consultó sobre la posibilidad de añadir un segundo cuerpo de acuerdo con el plan de Juan de la Torre y López a otro ya existente en la fachada del templo catedralicio segoviano que mira a la plaza mayor de la ciudad ${ }^{32}$. Los problemas adquirieron una envergadura mucho mayor al iniciarse el nuevo siglo, tal y como se pone de manifiesto en la acusación de Joaquín Antonio del

30 Sobre esta fachada véase el Archivo de la Academia de San Fernado: Actas de la Sección de Arquitectura desde 1786 hasta 1805: Legajo 3/139: Junta del 17 de diciembre de 1790 , pág. 153 y reverso, acta redactada por Joseph Moreno. Se prohibe continuar las obras de la Puerta de Santa María. También pág. 161 reverso y 162 anverso: Junta del 13 de mayo de 1791 sobre el diseño delineado por Fernando González de Lara para la obra de la puerta principal de la Catedral de Burgos con las consiguientes correcciones.- Informes de la Comisión de Arquitectura desde 1788 hasta 1797. Legajo 1-28/1: Carta de Josef Moreno, dirigida al Secretario de la Academia, indicándole la devolución con los correspondientes informes de los asuntos tratados en la Junta del 11 de febrero de 1791.

31 Archivo de la Academia de San Fernando (en adelante, AASF): Catedrales, 17661862. Legajo 2-32/5: Carta de Isidoro Bosarte dirigida al protector de la Academia fechada el 5 de febrero de 1794 sobre la representación de Joaquín de Herrera Lorenzana, canónigo de la Catedral de León sobre las obras que se hacen en esta Catedral sin permiso de la Academia. Carta de Fernando Sánchez Pentejo dirigida a Isidoro Bosarte fechada el 17 de mayo de 1794, indicándole que le remite ios dibujos de las obras que se realizan en el atrio de la Catedral de León.

32 AASF: Catedrales. 1766-1786. Legajo 2-32/5. Diversa correspondencia mantenida entre la Academia, y en su nombre por Luis Paret, con Fermin de Irigoyen y Antonio Álvarez Nava, canónigos de la Catedral de Segovia, y Francisco Rubio, su fabriquero. Están fechadas estas cartas el 10 de febrero, 14 de abril, 13 de junio, 19 de junio y 28 de julio de 1795, y 20 de noviembre de 1796. - También en Actas de la Sección de Arquitectura desde 1786 a 1805: Legajo 3/139. Junta núm. 119 del 13 de abril de 1795, firmada por Luis Paret.- Asimismo en 28-1/1: Carta de Luis Paret dirigida a Isidoro Bosarte, fechada el 19 de junio de 1795, indicándole la devolución de los asuntos tratados por la Comisión de Arquitectura en su Junta del 18 de junio. 
Camino a las realizaciones del Melchor de Prado en el interior de la Catedral de Lugo y en la contestación de éste, que delata precisamente ese fracaso del control de las obras, tal y como después ya se verá ${ }^{33}$.

Todo ello respondía precisamente a las tensiones entre el clasicismo y el gótico, y al deseo muy utópico de la Academia de controlar cuantas obras se hacían en el pais con muchos más deseos que medios prácticos. El final de ese conflicto se intentaria cerrar con otra idea irrealizable: la de buscar una reconciliación entre ambos lenguajes. Esta afirmación queda demostrada por la existencia en el Archivo de la Academia de Bellas Artes de San Fernando de una serie de manuscritos, en los que se intenta hallar un paralelismo entre la arquitectura clásica y el gótico, escritos por Custodio Teodoro Moreno en $1814{ }^{34}$, Miguel Antonio de Marichalar en $1819^{35}$, Pedro de Zengotita Vengoa y Pérez en $1821^{36}$ y Juan Marzo y Pardo en $1830^{37}$, que están necesitando la realización de un profundo estudio comparativo.

\section{LAS REALIZACIONES}

\section{El Transparente o Capilla de San Julián y el Altar Mayor de la Catedral de Cuenca}

Los proyectos diseñados por Ventura Rodríguez en octubre de 1752 para la catedral de Cuenca -el Transparente o Capilla de San Julián y

33 Sobre las denuncias de las obras de Melchor del Prado en la Catedral de Lugo: AASF: Catedrales, 1766-1786. Legajo 1-32/5. Carta de Joaquin Antonio del Camino dirigida a Isidoro Bosarte, fechada en Lugo el 6 de mayo de 1804, denunciando dichas realizaciones. Correspondencia interna de la Academia entre Isidoro Bosarte y Silvestre Pérez fechada el 7 de junio de 1804. Copias de cartas enviadas a Meichor del Prado con fecha de 11 de julio de 1804. Carta de Silvestre Perez del 16 de junio de 1804. Carta de Melchor de Prado y Mariño dirigida a Isidoro Bosarte y datada el 1 de agosto de 1804. Carta de Antonio de Lenzes dirigida a Isidoro Bosarte del 8 de agosto de 1804. Carta de Joaquín del Camino dirigida a Bosarte, fechada en Lugo el 16 de agosto de 1804.

${ }^{34}$ Custodio Teodoro MORENO. Paralelo entre la arquitectura griega y la gótica. Madrid 1814. AASF: $313-3 / 3$ y $324 / 3$.

35 Miguel Antonio MARICHALAR, Paralelo de la arquitectura griega con la homónima gótica. Toledo 1819. AASF: 576/3.

36 Pedro de Zengotita Vengoa Y PÉREz, Disertación del paralelo entre la Arquitectura griega y la gótica. Madrid 1821. AASF: 310-16/3.

${ }_{37}$ Juan MARZO Y PARDO, Disertación o sea paralelo ente la Arquitectura griega y gótica. Madrid 1830. AASF: $312-17 / 3$. 
el Altar Mayor- realizados por los maestros de las obras del Palacio Real de Madrid Gabriel Eugenio González, Pedro Ignacio de Incharraundiaga y Blas de Rentería, son, sin duda, una de las actuaciones internas más interesantes y llamativas de la segunda mitad del siglo XVIII en templos catedralicios góticos. El arquitecto de Ciempozuelos trató de armonizar eclécticamente en ellos las dos corrientes distintas de opinión que entonces existian en el Cabildo conquense: la de hacer una capilla a San Julián (1128-1208), segundo obispo de Cuenca tras de su reconquista, según los deseos del también Obispo San Martín, quien había cedido testamentariamente sus bienes en 1705 para realizarla, y la que defendia la idea de colocar una urna con el cuerpo del Santo en el Altar Mayor promovida por José Flórez Osorio, que entonces era Obispo de la sede. Ventura Rodríguez sustituyó para lograrlo el antiguo Altar Mayor por otro moderno de jaspe, que se correspondía con la capilla de los Pozos, ahora de San Julián. Así, deseaba crear unos espacios estilísticamente unitarios en correspondencia mútua y aislados del contexto general del primitivo edificio, en donde arquitectura y escultura se conjugan en una espléndida policromía conseguida a base de la alternancia de distintos materiales: mármoles blancos y azules de Urda (Toledo), amarillos de La Cierva (Cuenca) y verdes de Granada con otros blancos de Carrara y bronces dorados (figs. 13-17) ${ }^{38}$.

El Transparente o Capilla de San Julián, que fue inaugurada en octubre de 1760 por el Obispo Carvajal y Láncaster, presenta unas características escenográficas muy teatrales y marcadamente barrocas italianas dentro de un espacio reducido en la parte posterior de la capilla Mayor de la Catedral, en la crujía central de su deambulatorio. Es posible ver en esta obra la confluencia de varios estilos: del barroco clasicista

38 Sobre las obras realizadas por Ventura Rodriguez en la Catedral de Cuenca pueden verse: José Luis BARRIO MOYA, "Las obras de Ventura Rodriguez en Cuenca", Cuenca, núms. 19 y 20. Cuenca 1982, pág. 105. Del mismo autor: "Ventura Rodriguez y su obra en Cuenca. Nuevas aportaciones", Estudios sobre Ventura Rodriguez. Madrid 1985, pág. 147198. Barrio Moya se basa para la redacción de estos trabajos fundamentales en los documentos del Archivo de la Catedral de Cuenca, en sus Libros de Acuerdos de los años 1751-1756, 1760, 1767 y 1768, asi como en el Archivo de Protocolos de Cuenca, protocolo 1478, fol. 45-53 y en los Libros de Cuentas de San Julián.- F. INIIGUez ALmECH, "La formación de Ventura Rodríguez", Archivo Español de Arte, núm. 86. Madrid 1949.- Pedro NAVASCUES PALACIO, "LOS dibujos de Ventura Rodriguez para el Transparente de la Catedrai de Cuenca", Boletin de Información Municipal de Cuenca, julio-agosto-septiembre, 1972. núm 71, pág. 11-16.- Jesús Bermejo Diaz, La Catedral de Cuenca. Barcelona 1976, pág. 160-162. - En el libro Doménico Scarlatti en España con el catálogo de la exposición realizado bajo la dirección de Antonio BONET CORREA, Madrid 1985, se reproduce el proyecto para el altar mayor y capilla de San Julián de la Catedral de Cuenca en la pág. 299, ficha 361. localizándose en la Escuela Técnica Superior de Arquitectura de Madrid. 
italiano de Juvarra y Sachetti, con algunas notas de Bernini en los efectos de luz y la simple referencia, ahora muy depurada y acomodada a los nuevos tiempos, del Transparente de la catedral de Toledo de Narciso Tomé.

El sistema de iluminación empleado en esta capilla resulta muy interesante, pues la luz penetra de un modo oculto por medio de una ventana, situada encima de la estatua de la $\mathrm{Fe}$, que, como las otras dos Virtudes Cardinales sobre el frontón, todas ellas de tamaño natural, y los tres grandes relieves de escenas de la vida de San Julián fueron esculpidos por Francisco de Vergara en Roma entre 1758 y 1759, en donde estaba pensionado por el Rey Fernando VI, bajo la influencia clara de Bernini y con el empleo de mármoles de Carrara. Para que este camerín gozara de una mejor luminosidad el Cabildo encargó a Blas de Rentería que abriera una ventana circular en el muro gótico de la girola, de tal forma que la luz penetra de frente a la capilla, iluminando la urna del Santo.

Situado en la parte posterior del Transparente de San Julián se halla el nuevo retablo mayor, proyectado por Ventura Rodríguez en grandes dimensiones, y en estrecha relación estilística con él dentro del área de influencias del barroco italiano. Sustituyó al viejo, que estaba bastante deteriorado. Precedido por un presbiterio con adornos en estuco realizados por Pietro Ravaglio y Juan Bautista de Cremona, quienes también trabajaban en las obras del Palacio Real de Madrid, forma un espacio independiente, pero al mismo tiempo en contacto con la realidad de la catedral gótica, a la cual se acomoda estructuralmente a la perfección. El arquitecto usó en él, tal y como hiciera en la capilla, efectos policromos a base de alternancia de diferentes materiales. Enmarcado entre dos pares de columnas de capiteles corintios a cada lado y bajo un ático con frontón partido y dos volutas se halla el altorrelieve de la Natividad de Nuestra Señora, a cuyos flancos se dispusieron las estatuas de cuerpo entero de San Joaquín y Santa Ana, y en el centro en una hornacina sobre el entablamento a Dios Padre y el Espíritu Santo realizados todos ellos por el escultor Bociardi en Génova, así como los cuatro ángeles de las parte más alta del retablo.

\section{La nueva sacristía de la Catedral de Burgos}

La nueva sacristía de la catedral de Burgos, que se levantó en el mismo lugar ocupado por la vieja, antes las capillas del Sagrario y de los 
infantes de Carrión, fue proyectada por el jerónimo del monasterio de Mejorada fray Antonio de San José Pontones entre 1759 y 1761, fecha esta última en la cual se decidió al fin, luego de un momento de vacilaciones, el sitio en donde ubicarla y aplicar el dinero legado en 1758 por el Arzobispo D. Juan Francisco Guillén. La obra seria dirigida por el carmelita descalzo Fray José de San Juan de la Cruz, quien también hizo el diseño de la cajonería y de los respaldos según el modelo tomado de las Salesas Reales de Madrid. La sacristía se concluyó en su totalidad el 12 de enero de 1767 habiendo costado 247,182 reales (fig. 18).

El espacio disponible se compartimentó en dos estancias: la primera, la antesacristía, de planta rectangular, cubierta por una bóveda cuatripartita muy sencilla y con salida al claustro, se dispuso para guardar los ornamentos litúrgicos; y la segunda, la sacristía propiamente dicha, es muy alargada, un cuadrilátero irregular con el lado del fondo curvo y de una superficie aproximada de 80 metros cuadrados. Se cubre por medio de una bóveda elíptica sostenida por pechinas, recibiendo la luz de una linterna cilíndrica y seis ventanales de medio punto. Todo el conjunto resulta de un gran abigarramiento debido al empleo de pilastras de complejos y ricos capiteles corintios y entablamentos quebrados, y a la abundancia y a la menudencia de los adornos a base de figuras policromadas - cabezas aladas y ángeles músicos entre nubes- que cubre la bóveda en un manifiesto horror vacui, dinamismo y retorcimiento. Este recargamiento se acentúa aún más con los retablos existentes entre las pilastras, tallados en madera, sobre mesas obscuras ${ }^{39}$.

39 Sobre la sacristia de la Catedral de Burgos: Manuel MARTínez y SANz, Historia del templo catedral de Burgos, escrita con arreglo a documentos de su archivo... Burgos, imp. de D. Anselmo Revilla, 1866, pág. 106.-Pedro OrCajo, Historia de la Catedral de Burgos. Burgos, Imp. de Pacual Polo, 1845, pág. 62.-R. Amador de los Rios, España, sus monumentos y artes... Barcelona 1888, pág. 547.-Lena Saladina IGLESIAS Rouco, Arquitectura y urbanismo en Burgos bajo el reformismo ilustrado (1747-1813) Burgos, Caja de Ahorros Municipal, 1978, pág. 62-63, quien se basa documentalmente en el Archivo de la Catedral de Burgos, Reg. 107, Actas Capitulares 1758, fol. 479, 22 noviembre: Reg. 107. Actas Capitulares 1759, fol. 527, 2 de abril, y fol. 580, 3 agosto: Reg. 108. Actas Capitulares 1761, fol. 122, 19 de junio.-Pedro Navascues Palacio, Catedrales de España, por... y Carlos Sarthou Carreres. Madrid, Espasa-Calpe, 1983, pág. 75.- Marcos Rico SantamaRiA, La Catedral de Burgos. [Vitoria, Heraclio Fournier, 1985], pág. 297-300. 


\section{Capilla de Santa Tecla de la Catedral de Tarragona}

En esta misma línea casi rococó de la sacristía de la catedral de Burgos hay que situar la capilla de Santa Tecla de la de Tarragona, realizada entre 1760 y 1775 por el arquitecto José Prat (1726-1790). Situada al lado de la Epístola ocupa el espacio dedicado anteriormente a baptisterio. Esta transformación fue promovida por el arzobispo Manuel de Samaniego y realizada ya en tiempos de D. Jaime Cortada. Hay en tal obra una yuxtaposición de tendencias artísticas, pues en ella se pueden hallar tanto elementos barrocos como rococós - sobre todo en las esculturas de Carlos Salas muy decorativas, escenográficas, que representan a las Virtudes Cardinales y los relieves con escenas de la vida de la titular- y aún cierto aire clasicista perceptible en el uso de ricos mármoles, el empleo de pilastras de orden compuesto y la distribución espacial de estas esculturas ${ }^{40}$.

\section{Reformas en el presbiterio y capilla de San Froilán de la Catedral de Lugo}

Julián Sánchez Bort proyectó en 1769 la fachada principal de esta vieja catedral gallega. En ella está presente la influencia de Ventura Rodríguez con el uso de un lenguaje barroco clasicista muy italiano y el empleo del orden gigante en columnas y pilastras, que se elevan sobre altos pedestales. Sus dos pisos, culminados por medio de una balaustrada, se articulan simétricamente en cinco calles, la central rematada por un bello frontón triangular. Sendas torres, cuyos cuerpos altos terminó Nemesio Cobreras ya en 1880 , se elevan sobre los extremos (fig. 19).

También se pueden hallar en el interior de la Catedral de Lugo -en donde se encuentran casi todos los estilos desde el románico al neocla-

40 Inventario artistico de Tarragona y su provincia. Madrid 1980, t. III, pág. 93.-Pedro NAvASCUES, "La formación de la arquitectura clásica", La época de la llustración. El Estado y la Cultura (1759-1808). Madrid. Espasa-Calpe, 1987, pág. 691-692, y del mismo autor Catedrales de España, obra citada, pág. 300.-P. BATLLE, La Catedral de Tarragona. León 1979. 
sicismo y se advierte la presencia singular del barroco gallego en la Capilla dedicada a Nuestra Señora de los Ojos Grandes, patrona de la ciudad, realizada entre 1726 y 1737 por Fernando Casas Novoa con la participación de Ferro Caaveiro- algunas transformaciones importantes proyectadas durante la segunda mitad del siglo XVIII. Las más significativas afectaron al presbiterio y a la capilla de San Froilán. En aquella reforma intervino el arquitecto francés Carlos Lemaur en 1762. Se desplazó el antiguo altar mayor de estilo plateresco hecho por Corneilles de Holanda en 1532 a la cabecera de la nave del crucero. El nuevo retablo fue proyectado por Pedro Ignacio Lizardi y realizado por José de Elejalde en ricos materiales, buscándose bellos efectos policromos con la alternancia de los mármoles negros jaspeados de las cuatro columnas muy esbeltas dispuestas de forma semicircular, de los rojizos de las otras columnas que sostienen un gran entablamento, y de los blancos de los cuatro ángeles orantes. Una bella imagen de la Asunción de la Virgen le preside. La capilla, bajo la advocación de San Froilán, el Santo patrono de Lugo, fue construida en 1780. Es de planta rectangular cubierta con una bóveda de arista, que descansa sobre arcos rebajados. En su cabecera se halla un retablo de orden corintio y pétreo de 1796, obra de Manuel Luaces, policromada por Rodríguez Adrián ${ }^{41}$.

\section{El altar mayor de la Catedral de Segovia}

Interesa destacar aqui de una forma muy especial por su significado e incidencia posterior el magnífico y rico altar mayor de la catedral tardogótica de Segovia, que Francisco Sabatini, entonces coronel de Ingenieros, proyectó en 1768. Podria considerarse como el prototipo casi ideal de los retablos españoles de la segunda mitad del siglo XVIII debido a la depuración clasicista de sus líneas y a la nobleza de los materiales empleados, prototipo que la carta circular de Carlos III, fechada el 25 de noviembre de 1777 y dirigida a las jerarquias eclesiásticas, promovía a petición de la Real Academia de Bellas Artes de San Fernando bajo la inspiración clara de Antonio Ponz. Esta medida, renovada ya el 8 de noviembre de 1791 durante el reinado de su sucesor Carlos IV, obedecía

${ }^{41}$ Inventario artístico de Lugo y su provincia. Madrid, Centro Nacional de Información Artística y Arqueológica, 1980, pág. 11-25. 
a la idea de depurar las extravagancias arquitectónicas y escultóricas barrocas, denunciadas por el secretario de esa institución en el libro que relata sus viajes por España, y sobre todo de sus recargados retablos, realizados en madera. Se deseaba conseguir tanto la depuración clasicista de sus formas como el uso de unos materiales más nobles -en especial el mármol, el jaspe y el bronce, aunque también se admitia el empleo de la piedra y el estuco-, más duraderos y resistentes al fuego, pues su fácil combustión había provocado el incendio de numerosas iglesias ${ }^{42}$.

Esta disposición ha sido recientemente estudiada en profundidad por Alfonso Rodríguez $\mathrm{G}$. de Ceballos en un artículo importante, en el que se demuestra la buena aceptación que tuvo por parte de los estamentos eclesiásticos, sobre todo de aquellas jerarquías más vinculadas con la ideología jansenista ${ }^{43}$. Y ello se logró a pesar de la ingerencia manifiesta del rey en competencias exclusivas de la Iglesia, delegando en su Real Academia madrileña dicho control y su cumplimiento en la justicia civil. Pero la acogida estaba ya precisamente propiciada por las ideas reformistas, projansenistas y antijesuíticas, imperantes.

Carlos III costeó este retablo, que consta de tres cuerpos de alturas diferentes. El primero se corresponde con el zócalo de mármol negro jaspeado de blanco y pedestal. El intermedio está dividido en tres calles por columnas de basas áticas, fustes lisos y capitales corintios de bronce. En la hornacina central, rematada por un pequeño frontón semicircular presidido por dos ángeles de bronce, que sostienen una corona de flores, se halla la imagen gótica de Nuestra Señora de la Fuencisla, y en los laterales las de San Frutos, patrón de la diócesis, y San Geroteo, primer

42 Juan José MARTiN GONZÁLEZ, "Problemática del retablo bajo Carlos Ill», obra citada en nota 4, pág. 35.-Arturo HERnÁNDEZ OTERO, "El altar mayor de la catedral". Estudios Segovianos, t. IV. Segovia 1952, pág. 281-322.-Antonio Ruiz Hernando, “El Altar Mayor de la Catedral". Estudios Segovianos, t. IV, 1952, pág. 314-315.-Valentín PiCATOSTE, Descripción é historia politica, eclesiástica y monumental de España para uso de la juventud. Provincia de Segovia. Madrid, Libreria de la viuda de Hernando, 1890. Facsímil en Segovia, Caja de Ahorros, 1975.-Dionisio Yubero Galindo, La Catedral de Segovia. Recuerdo de la visita a la santa iglesia catedral. $3 .^{\circ}$ ed. Segovia, El adelantado de Segovia, 1978.-Miguel DE GRIJALBA, "Apuntaciones de la obra del Altar Mayor de jaspes y bronces dorados, que de orden y a expensas del Rey Dn. Carlos Tercero se ha puesto en la Capilla Maior de esta Sta. Iglesia de Segovia, se concedió esta gracia y se principió la obra siendo Obispo el IImo. Sr. Dn. Juan Joseph Martínez Escalzo, y se perfeccionó en tiempos del limo. Sr. Dn. Alfhonso Marcos de Llanes". Manuscrito, cuaderno tamaño folio, firmado el 22 de noviembre de 1775. ACS.

${ }_{43}$ Alfonso Rodriguez G. de Ceballos, "La reforma de la arquitectura religiosa en el reinado de Carlos III", obra citada en nota 3. 
Obispo segoviano. Estas dos esculturas fueron realizadas por Manuel Adeba Pacheco, mientras que los bronces se deben a José Pichardoni y Antonio Vendetti. Las columnas sostienen arquitrabe, friso y cornisa saliente. En el tercer cuerpo se encuentran las imágenes sedentes de los mártires segovianos Santa Engracia y San Valentín, dispuestas sobre la cornisa, en cuyo centro se colocó el anagrama de María rodeado por nubes, rayos solares y cabezas de serafines. El frontón está presidido por una gran cruz dorada, que un ángel sostiene entre sus manos, mientras que otros dos arrodillados la contemplan en éxtasis (fig. 20).

La complejidad iconográfica de este retablo, consagrado el 7 de septiembre de 1775, presidido por la Virgen de la Paz bajo la exaltación de la Cruz y la tutela de los santos locales, y de algunas formas y actitudes escultóricas contrasta con su austeridad arquitectónica y la variada utilización de los materiales nobles.

\section{La sacristia y la capilla Palafox de la Catedral de Burgo de Osma}

Las realizaciones arquitectónicas de la segunda mitad del siglo XVIII en la entonces bastante ruinosa catedral de Burgo de Osma (Soria) poseen el gran atractivo de haber empleado en ellas a varios de los arquitectos más importantes del reinado de Carlos III. Así, si Ventura Rodriguez proyectó en 1755 un nuevo templo irrealizado inspirado en el catedralicio de Valladolid, otra fachada y una serie de obras para consolidarlo, José de Hermosilla sería el autor del plan definitivo de restauración en 1758, un Juan de Villanueva, aún jóven y sin grandes experiencias, ideó tanto la sacristía como la capilla Palafox, y Sabatini inspeccionaría los trabajos en 1778. A estas cuatro actuaciones muy significativas y que también dan idea de la importancia que tales realizaciones tuvieron para la Corona, hay que añadir, además, las de Juan de Sagarvinaga, quien hizo la torre que Domingo de Ondatégui proyectó ya en 1739 y fue autor de, al parecer, un primitivo plan de 1760 para dicha capilla que sería sustituido por el de Villanueva, a Angel Vicente Ubón, ejecutor material de los proyectos, y a Luis Bernasconi, que las concluyó en 1783. Junto a ellos y a un doble nivel tanto político como de patronazgo se debe situar al mismo monarca bajo la inspiración de su confesor el Padre Fray Joaquín de Eleta, el siempre devoto del venerable Obispo D. Juan de Palafox (1654-1659) e hijo de la villa, y a quien ocupaba entonces el Obispado, el culto D. Bernardo Antonio Calderón (1764-1786). 
Chueca Goitia opina que el diseño de la sacristía (figs. 21 y 22), fechado en 1770, de Juan de Villanueva, a quien se le encargaron la realización de estas obras por mediación del Padre Eleta, tiene una clara inspiración en el orden corintio usado por Vignola y manifiesta también la influencia indudable de Ventura Rodríguez ${ }^{44}$. Se construyó en un sitio próximo al Altar Mayor del templo, en el lugar ocupado por las antiguas casas consistoriales, que previamente habian sido derribadas y que ahora se instalaron en los nuevos edificios de la plaza principal bajo la dirección de Ubón. La planta de la sacristia es un rectángulo algo corto y desproporcionado de tres tramos cubiertos por una bóveda de cañón de medio punto con lunetos, muy similar a la empleada por Rodríguez en su actuación en la Encarnación de Madrid en 1767. En la cabacera se abre un ábside semicircular con cúpula nervada de cuarto de esfera. La planta sigue, según Kubler «el sistema convencional de la sacristía española" ${ }^{45}$. En los muros realizó una serie de arcosolios, arcadas de medio punto entre pilastras corintias, y un bellísimo entablamento contínuo. La totalidad de la obra, aislada espacialmente del goticismo de la iglesia, se muestra dentro de una tendencia manifiestamente barroca clasicista.

La Capilla del Venerable Palafox (figs. 23, 24 y 25) también se construyó en un espacio totalmente independiente con relación a lo conservado de la catedral gótica. Está situada detrás del Altar Mayor y tiene su entrada por la girola, realizada entonces, a través de una bella portada clásica, formada por un arco de medio punto flanqueado por dos columnas muy esbeltas de orden jónico, que sostienen un entablamento. Sobre él se alza un frontón triangular. La planta resulta bastante compleja para sus dimensiones reducidas. Poseé forma de rotonda con cuatro aberturas entre dos grandes columnas in antis, que se corresponden respectivamente con dicha entrada, las capillas laterales y la mucho más profunda del altar mayor. Según la opinión de Kubler, se forman como cuatro

44 Fernando Chueca Goitia, "La arquitectura religiosa en el siglo xvIII y las obras del Burgo de Osma", obra citada en nota 10. Véase pág. 301-302. Muchas de las noticias aportadas por Chueca se extrajeron del manuscrito titulado «Apuntes de las cosas curiosas consignadas en las Actas Capitulares de la Catedral de Osma", tomados por el canónigo Sinforoso DE LA CANTOLLA, y que se conservan en el Archivo de la catedral. Además de la bibliografía citada en nota 10: LOPERRAEZ, Descripción histórica del Obispado de Osma. Madrid, Imp. Real, 1788._- “Juan de Villanueva en la Capilla del Venerable Palafox y la Sacristia de la Catedral del Burgo de Osma", Arquitectura, año LXIV, IV. época, núm. 244. Madrid, septiembre-octubre, 1983, pág. 34-37.

45 KUBLER, Arquitectura de los siglos XVII y XVIII, obra citada en nota 11, pág. 259-260. 
fachadas internas. Fue proyectada, asimismo, en 1772 por Juan de Villanueva. El maestro Ubón estuvo encargado de la construcción hasta su muerte, sucediéndole Luis Bernasconi. Sabatini reconoció la obra realizada en septiembre de 1778 y diseñó un nuevo plan para concluirla, Io que tuvo lugar en 1781. Dos años después, el 27 de septiembre de 1783, seria inaugurada.

Varios estudiosos de esta capilla coinciden en destacar, como uno de sus aspectos más significativos, el empleo que el arquitecto hizo de la columna exenta con un claro sentido ya neoclásico y con el uso de plintos y capiteles circulares en concordancia con la misma forma de la planta. También suelen destacar una cierta influencia de Palladio en su conjunto y la referencia clara al Panteón de Roma, atribuyendo al italiano Sabatini la realización del corto tambor y de la cúpula ornamentalmente recargada.

\section{Reformas en la Catedral de Almería}

El singular edificio de la Catedral-fortaleza tardogótica y renacentista de Almería, cuya primera piedra se colocó ya el 4 de octubre de 1524 , durante el Obispado del franciscano D. Fray Diego Fernández de Villalán, y en donde lo religioso y lo militar se conjugan admirablemente, presenta buenos ejemplos de arquitectura de esta época. Así se puede observar tanto en la mesa de altar y Tabernáculo de la Capilla Mayor y en el trascoro, obras realizadas bajo el patrocinio del Obispo D. Claudio Sanz y Torres y Ruiz de Castaneda (1704-1779) entre los años de 1773 y 1777, como en el claustro. Aquellas construcciones, ejecutadas por Eugenio Valdez, fueron supervisadas por la Real Academia de Bellas Artes de San Fernando. Ventura Rodriguez introdujo correcciones a los proyectos iniciales. Hay una relación material y formal entre la mesa, cuyo frontal está ocupado por tres medallones, y el Tabernáculo y el trascoro (fig. 26) hechos en ricos mármoles. Este último consta de tres calles separadas por columnas y pilastras de fustes grises de tonalidades oscuras y de orden corintio, destacando de entre ellas la central en donde se dispuso en el interior de una hornacina la imagen de la Purísima Concepción, esculpida en alabastro hacia el año 1804, flanqueada por las repre- 
sentaciones de Santo Domingo de Guzmán y San Juan de Nopomuceno, vestidos con el hábito coral de lós canónigos catedralicios ${ }^{46}$.

El Tabernáculo de la Catedral de Almería (fig. 27) se aiza sobre y tras de la mesa del Altar y consta de tres cuerpos. Las esfigies de cuatro apóstoles, entre ellos de San Pedro y San Pablo, en la parte anterior, esculpidas en mármol blanco de Carrara, flanquean al Sagrario en las esquinas del frontispicio, en donde también hay ocho medios relieves. En el central se alza el templete, que consta de cuatro arcos de medio punto, que se relacionan con los abiertos en los muros de la Capilla, en cuya bóveda se albergan las imagenes duplicadas de San Indalecio, entre ocho esbeltas columnas pareadas realizadas en jaspe. En el tercer cuerpo se alza la cúpula sobre un entablamento y entre las estatuas de los otros ocho apóstoles esculpidos, como áquellos, en mármol blanco, que se relacionan con dichas columnas. La figura del Salvador corona el conjunto.

También se hizo entonces la mesa del Altar, bellamente policromada por medio del empleo de mármoles y jaspes de diferentes colores y con medallones blancos, en donde se representa, entre otras escenas, la Encarnación, esculpidas todas ellas, al parecer, por Valdez y mutiladas durante la Guerra Civil. Esta obra se completa con la realización anterior, de hacia 1768 , de las gradas del presbiterio, la urna de plata para el tabernáculo de 1757, los dos púlpitos del tallista Montano, terminados en 1781, y el órgano del maestro Leonardo Fernández Dávila.

Juan Antonio Munar proyectó en 1786 el bello claustro (fig. 28) de este templo, cuyas obras se terminaron en 1795, y en donde ya se percibe un tratamiento formal totalmente neoclásico. Consta de arcos de medio punto entre columnas de orden jónico semiadosadas a los machones. Sobre los capiteles y con ménsulas, que se apoyan en las claves de dichos arcos, se disponen el friso y el arquitrabe lisos, tan sólo orlado por bandas horizontales. La obra manifiesta una gran sencillez de líneas,

46 José Ángel TAPIA GARRIDO, Almería piedra a piedra. Biografía de la ciudad. [Almería, Monte de Piedad y Caja de Ahorros de Almería, 1970]. Véase capítulos XXXVII-XXXIX, pág. 306-341. Tapia utilizó a la hora de referirse a las obras realizadas en esta catedral de Almería en la segunda mitad del siglo xvIII los documentos existentes en el Archivo de la Catedral de Almería y, especialmente, los Libros de Actas: Altar Mayor: ib. 20, fol. 165 y 168, lib. 31, fol. 17-36 y 111.-Tabernáculo: Lib. 35, f. 139; lib. 41, f. 76-77; lib. 43, f. 10, 216.-Trascoro: Lib. 36, f. 309v; lib. 37, f. 195; lib. 54, s.f.; lib. 56, f. 116.-Claustro Lib. 45, f. 323 y $287 \mathrm{v}$; lib. 46 , f. 362 y 408 ; lib. 49 , f. $9 v$ y y 320.- También: La Catedral de Almería. Con textos de Manuel Rodriguez, Lucas Ramos, Juan López y Miguel Sánchez. [León] ed. Everest [1975]. 
pudiéndosela considerar como uno de los claustros más significativos del neoclasicismo español, a pesar de que contraste, en general, con el resto de la catedral y, en particular, con la puerta gótica isabelina de entrada a la iglesia.

En el archivo de la Real Academia de San Fernando se halla un legajo sobre las Catedrales con una serie de documentos, que se ocupan de la construcción del claustro del templo catedralicio de Almería. El 1 de julio de 1785 Juan Francisco Lastiri envió de orden de la Cámara a Antonio Ponz el expediente original en 28 folios con el diseño, realizado por Juan Antonio Munar, arquitecto director de las obras de Fábricas del Obispado de Almeria, y su parecer, fechado el 8 de Abril, para la construcción de un Panteón o cementerio, a fin de que fuera examinado por la Academia. El secretario de esta institución contestó el 20 de septiembre de ese mismo año, indicando que la Real Academia de San Fernando «prefiere la obra del claustro propuesta por el Sr. Obispo de Almería al del embaldosado de la Catedral, por ser más conforme aquel espacio á la disciplina eclesiástica antigua que se promueve sobre los enterramientos". Ponz añadia, que los dibujos los habian encontrado apropiados, y estableció una serie de correcciones: la conveniencia de estrechar los arcos inmediatos a los cuatro ángulos y añadir una pilastra en cada rincón, que tuviera igual salida a la de las columnas por la parte del capitel, para que pudiera recibir el ornato del cornisamento; que el diámetro de las pilastras del claustro fuera igual al de las columnas; y que la balaustrada descansara, sacándola más afuera, sobre el vivo del arquitrabe ${ }^{47}$.

En las actas de la Junta del 6 de marzo de 1792 de la Comisión de Arquitectura se hace referencia al examen del informe de inspección de la obra del panteón y claustros por orden del Consejo del arquitecto

47 En el Legajo 2-32/5, Catedrales. 1776-1862, del Archivo de la Real Academia de Bellas Artes de San Fernando hay varios documentos sobre la realización del claustro de la Catedral de Almeria: "Carta de Juan Francisco de Lastiri dirigida a Antonio Ponz, fechada en Madrid el 1 de julio de 1785 en la que le indica que le remite los planos de Juan Antonio Munar para la construcción de un Panteón o Cementerio".- "Carta de Antonio Ponz dirigida a Juan Francisco de Lastiri, fechada en Madrid el 20 de septiembre de 1785, informándole de que la Real Academia de Bellas Artes de San Fernando ha visto los planos de Munar, prefiriendo la realización de un claustro al embaldosado del templo y señalando algunas correcciones a dichos dibujos". - "Carta del Marqués de Murillo dirigida a José Moreno, fechada el 19 de octubre de 1791 sobre el expediente de obras en la Catedral de Almeria"- - "Carta del Marqués de Murillo dirigida a José Moreno, fechada en Madrid el 21 de octubre de 1791, indicándole que le devuelve los expedientes relativos a obras en la Catedral de Almeria". - "Carta del Marqués de Murillo dirigida a Antonio Ponz. fechada en Madrid, el 3 de junio de 1797". 
Domingo de Tomás, fechado el 22 de febrero de ese mismo año y remitido por el Marqués de Murillo, Secretario de la Cámara de Castilla, a la Academia de San Fernando. En ellas se aprobó dicho dictamen, indicándose a continuación lo siguiente: «Pero sin embargo considero por defecto esencial el que la puerta de comunicación $A$ desde el Crucero de la Iglesia no se dirija rectamente à la del Claustro anotada con la letra $B$, atendiendo a que estos defectos de pura necesidad, las más de las veces irremediables, no se deben reputar por más que de leve consideración; y en orden al asiento de la pilastra, que bastará para darlas mayor solidez à los cimientos fortificar la zarpa puesta hasta la losa de elección, en el modo que señaló la misma Junta con lápiz en el plano de Tomas» ${ }^{48}$.

También se hicieron reformas en la Capilla de San Indalecio, construida en 1562, costeadas por Sanz y Torres, quien donó en 1777 al Cabildo la cantidad de 60.000 reales para su embellecimiento. Entre 1781 y 1785 , fecha de su nueva apertura al culto, fue adornada y estofada por Vicente Navarrete, mientras que Francisco Testa levantó el nuevo retablo y Salcillo enviaba en 1782 la imagen del Santo titular.

\section{El trascoro de la Catedral de Segovia}

Las obras, que se hicieron en el trascoro de la catedral de Segovia a fin de adaptar en él el retablo de mármol realizado por Huberto Demandre en 1758, procedente de la capilla elíptica del Palacio de Riofrío, para la cual se proyectó, tienen un significado muy especial dentro de estas transformaciones de la segunda mitad del siglo XVIII en templos catedralicios góticos (lám. XXIX). Ello se debe a la concurrencia de diversas circunstancias, pues en la realización intervendrían consecutivamente Juan de Villanueva y Ventura Rodriguez, debiendo este último acomodarse a las soluciones planteadas en el proyecto del primero,

48 AASF: Actas de la Sección de Arquitectura. Desde 1786 hasta 1805, Leg.: 3/139. Acta de la Junta del 6 de marzo de 1792. Sobre la inspección del arquifecto Domingo Tomás del claustro de la Catedral de Almeria y defectos encontrados. - Leg.: 1-28/1: Informes de la Comisión de Arquitectura. 1788-1797: Carta-oficio de Luis Paret, dirigida a Isidoro Bosarte, relacionándole la devolución de los expedientes despachados en la Junta del 27 de marzo de 1792, entre ellos de la declaración de Domingo Tomás sobre defectos hallados en el claustro de la Catedral de Almeria. 
quien al final renunció a dirigirlas. Además, en tal intervención se plantearian importantes problemas espaciales y de ajuste de diferentes gustos y tendencias artísticas. Asi, en primer lugar era preciso hacer conjugar un retablo barroco romano con un escenario gótico, para el cual no había sido pensado, y, también, a áquel a una nueva idea arquitectónica mucho más depurada, como era la de Juan de Villanueva, quien, si no se hubiera visto obligado por las circunstancias, habria prescindido de dicho retablo, que no se acomodaba a su estética; pero la donación de Carlos III al Cabildo por petición del mismo, la mediación de Floridablanca y la actitud de los canónigos le hicieron desistir de su colaboración.

Existían, tal y como Antonio Ruiz Hernando ha puesto de manifiesto, dos concepciones espaciales y estilísticas encontradas en ese año de 1783 entre Joaquín Demandre, hijo del autor del retablo, al que había desmantelado y trasladado a la catedral de Segovia, y Juan de Villanueva ${ }^{49}$. Este entró en la obra por nombramiento de Floridablanca ante la división de opiniones existentes en el Cabildo y dado el derecho de la Corona a intervenir en la misma. Aquel era partidario de que no se adosara al muro del trascoro, sino de que se adelantara hasta el eje de los dos pilares del segundo tramo, a fin de construir en el espacio intermedio una sacristía cerrada. Creía necesario, además, añadir dos calles, una a cada lado, a dicho retablo para que se adaptara a la anchura de la nave. Villanueva, por el contrario, disentía en esta solución. Pensaba que se debía colocar pegado a ese muro, al cual prolongaba lateralmente para crear, así, una capilla abierta delante del trascoro. Su concepción arquitectónica era, también, mucho más clásica que la de Demandre, ya que su proyecto suprimía una serie de elementos existentes en el anterior: el frontón curvo, las pilastras, las puertas y le restaba verticalidad. Pero su idea no fue ni comprendida ni aceptada por el Cabildo, que deseaba que el arquitecto madrileño se acomodase a sus correcciones,

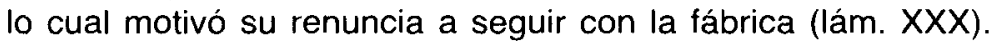

La solución a tal problema se encontraría en la persona de Ventura Rodríguez, quien hubo de aceptar en gran parte el plan de Villanueva bajo la presión de Floridablanca, al mismo tiempo que el antiguo Obispo de Segovia, D. Alonso Marcos Llanos, ahora Arzobispo de Sevilla, influía en idéntico sentido en el Cabildo. El nuevo proyecto, fechado en septiembre de 1784, es ecléctico entre ambas tendencias, pues, si por una parte respetaba la idea de Demandre de avanzar e! retablo para aprovechar

49 Antonio Ruiz HeRnando, "Ventura Rodríguez y Juan de Vilianueva en el trascoro de la Catedral de Segovia», obra citada en nota 15. 
los cimientos existentes, por la otra asumía la concepción formalmente clasicista de Villanueva, al despojarle de verticalidad y de excesivos adornos (lám. XXXI y XXXII).

En la Junta de la Comisión de Arquitectura de la Academia de San Fernando del día 15 de enero de 1790 se presentaron dos dibujos disenados por Juan de la Torre y López para el adorno de los costados del coro de la Catedral de Segovia, aportándose también cinco métodos para su enlosado. La Comisión resolvió que la obra de los costados se arreglase a la del trascoro según la solución dada por el entonces difunto Ventura Rodríguez y se enmendaran, si ello era posible, las partes que el constructor Estévez alteró al hacerlo. Como sistema de enlosado se eligió el de clistas alternadas de los tres colores, puestas por ángulo, siendo las cintas de todo el contorno negras $"{ }^{50}$.

\section{La remodelación del interior de la Catedral de Valencia}

La remodelación por medio del empleo de un lenguaje barroco clasicista del interior de la catedral de Valencia, debida al arquitecto Antonio Gilabert y realizada entre 1774 y 1792, fecha de su muerte, es, quizás, una de las transformaciones arquitectónicas más interesantes por su significado de la segunda mitad del dieciocho en templos catedralicios bajomedievales españoles (láms. XXXIII y XXXIV). Con esta reforma se trataba de ocultar su realidad gótica a base de unas añadiduras novedosas de ladrillos, piedras, jaspes y estuco. Todo ello obedecía a la idea de adaptar la catedral al nuevo gusto de la Academia de San Carlos, y en tal actuación parece confirmarse el principio expuesto por Isidoro Bosarte de la adecuada posibilidad de actuar en edificios de este estilo con el uso de un lenguaje clásico, que es considerado superior como sistema arquitectónico. Hay, así pues, en este ejemplo una ocultación bien significativa de otra realidad estilística, a la que parece desposeérsela de su sentido de sistema permisible, prescindiéndose de todo nostálgico sentimentalismo romántico historicista y viéndose racionalmente el dinamismo biológico arquitectónico de la catedral, susceptible de ser transformada para acomodarse a los nuevos tiempos.

50 AASF: Actas de la Sección de Arquitectura. Desde 1786 hasta 1805. Leg.: 3/139. Acta de la Junta del 15 de enero de 1790 . Se refiere a la presentación de dos dibujos para el adorno de los costados del coro de la Catedral de Segovia por Juan de la Torre y López y resolución de dicha Comisión de Arquitectura. 
Sin embargo, no se puede ver este hecho, cual los demás que ya han sido tratados antes aquí, como un fenómeno aislado, descontextualizado de la historia, pues, en realidad, la actividad de Gilabert en este caso concreto de la catedral de Valencia obedecía a una tradición. Significaba la continuidad de un ambicioso programa arquitectónico, no codificado unitariamente, de renovación, iniciado ya en pleno período barroco por Juan Pérez Castiel entre 1674 y 1682, quien se ocupó, sobre todo, del presbiterio, y que se siguió durante la primera mitad de la centuria dieciochesca con la realización de diversos lucimientos de las capillas del ábside y la construcción de un camarín en la de San Luis obispo. $Y$, además, este mismo comportamiento arquitectónico de renovación de templos valencianos de otras épocas se había dado durante todo el siglo XVII en muchas iglesias góticas, que eran adaptadas al sistema barroco por medio de múltiples recursos arquitectónicos, como, por ejemplo, construyendo bóvedas de cañón, que ocultaban las primitivas, cubriéndolas a base de estucos añadidos y redondeándo los arcos apuntados.

Resulta muy interesante el analizar aquí, aunque sea brevemente, el proyecto de Antonio Gilabert por medio del cual se deseaba convertir la estructura gótica del templo en otra totalmente palladiana. Su plan, mucho más esquemático y desornamentado que el irrealizado de Vicente Gascó, su oponente en el concurso 1773, consiste en la rítmica disposición de dos series de arcos superpuestos. Los superiores arrancan de pilares de capiteles corintios enmarcados entre dinteles, mientras que los inferiores descansan sobre columnas pareadas. Los arcos apuntados góticos se transformaron, así, en de medio punto con otro inscrito en cada tramo.

Joaquín Bérchez ha estudiado recientemente con minucia las distintas fases de la compleja remodelación de la catedral valenciana y también ha comentado algunas de las opiniones más significativas, que tal obra suscitó en autores tales como Antonio Ponz, José Ortiz y Sanz y en el arquitecto romántico Ximénez y Cros. En este sentido se puede advertir, así mismo, el significativo cambio de gusto experimentado entre una y otra tendencias y la disconformidad del incansable caminante español con la disonancia resultante en el contraste entre el clasicismo novedosos de las realizaciones de Antonio Gilabert y las bóvedas góticas, que entonces se conservaron, discordancia arquitectónica acentuada con cierta acritud por los juicios publicados ya durante el romanticismo ${ }^{51}$.

51 Joaquín BERCHEz, Los comienzos de la arquitectura académica en Valencia: Antonio Gilabert, obra citada en nota 2. También S. ALDANA, Antonio Gilabert, arquitecto neoclásico. Valencia 1955. 


\section{Reformas en el interior de la Catedral de Sevilla}

Durante la segunda mitad del siglo XVIII hubo realmente muy poca actividad artística en la opulenta Catedral de Sevilla, contrastando este periodo con la riqueza de la imaginería barroca. Tan sólo es de destacar aquí el discreto retablo neoclásico de la Capilla de San José, diseñado por Pedro Arnal en un lenguaje académico entre 1785 y 1800 . De un cuerpo con ático rematado por un frontón semicircular fue realizado con la alternancia de mármoles de diversos colores. En la calle central, y flanqueada por dos columnas corintias, está la imagen del Santo titular, que sostiene entre sus brazos al Niño Jesús, bajo el cual juegan cuatro angelitos. Es obra tallada ya en 1800 en madera policromada por José Esteve Bonet, Director de la Academia de San Carlos de Valencia. A ambos lados se representan a San Miguel Arcángel y, al parecer, a San Blas. Sobre el ático, y entre las figuras de Santa Teresa y Santa Lucía, hay un tondo hecho también por Alfonso Bergaz con un medio relieve, en donde aparece Santo Domingo recibiendo el rosario ${ }^{52}$.

Poco más se puede añadir aquí sobre las reformas interiores de la Catedral sevillana, en donde parece reflejarse artísticamente la decadencia económica sufrida por la ciudad durante la llustración. Sin embargo, son reseñables una serie de realizaciones como la costosa e ingente obra del enlosado del templo, actividad que ocupó mucho tiempo y que no se terminaría hasta 1793. El enladrillado antiguo sería sustituido por mármoles de Génova. Los gastos corrieron a cargo del Cardenal Delgado, del Arzobispo y del deán Ignacio Cevallos.

Dentro de otro género artístico, el de las artes aplicadas e industriales, también hay que destacar la realización de rejas, que inciden en la arquitectura, durante esta época: las de la Capilla Real y de San Pedro. La primera de ellas fue costeada por Carlos III y diseñada por Sebastián Vander Borcht. Esta obra de 1773 se distribuye como un gran retablo en tres calles, separadas por doble pilastra, y dos cuerpos, rematados por medio de una balaustrada, y un frontón curvo, en cuya cúspide se representa en figuras atribuidas a Jerónimo Roldán la entrega de las llaves de la ciudad al rey Fernando III el Santo por Axataf tras de su reconquista en 1248. El conjunto, muy bello, resulta de una gran monumentalidad. La

52 La Catedral de Sevilla, obra citada en nota 12. Véase: J. Alfredo MORALES, “La arquitectura de la Catedral de Sevilla en los siglos XVI, XVII y XVIII” (pág. 173-220), pág. 214215, y José HeRnández Diaz, “Retablos y esculturas" (pág. 221-320), pág. 307-308. 
segunda reja, la de la Capilla de San Pedro, se hizo entre 1778 y 1780 por el franciscano José Cordero y se inspira en la de la Concepción Grande. Por último, también hay que reseñar aquí la instalación en el lado de la Antigua en 1792 del nuevo órgano construido por Jorge Bosch $^{53}$.

En el Archivo de la Real Academia de Bellas Artes de San Fernando, queda constancia del envío de cuatro dibujos para una sillería, facsistol y otros adornos de la Capilla Real dedicada a este Santo en Sevilla, ejecutados por el académico Antonio Fernández Bertoni, remitidos por Antonio Ponz a José Moreno el 8 de junio de 1790 para ser examinados en la Junta de la Comisión de Arquitectura del dia 12 de ese mismo mes. Fueron aprobados, indicándose que se realizaron de orden y a expensas de S. M. ${ }^{54}$.

En las Juntas del 28 de febrero y 30 de marzo de 1805 de la Comisión de Arquitectura de la Real Academia de Bellas Artes de San Fernando, firmadas por Silvestre Pérez, se aprobaron dos diseños realizados por Antonio Aguado para la construcción de un altar en la capilla de los Dolores junto a la Sacristía de los Cálices en esta Catedral de Sevilla ${ }^{55}$.

\section{Proyectos para obras en el interior de la Catedral de Murcia}

Queda constancia en el Archivo de la Real Academia de Bellas Artes de San Fernando de un par de proyectos para este templo. El primero

53 Alfredo MORALES, "Artes aplicadas e industriales en la Catedral de Sevilla", en La Catedral de Sevilla, obra citada en notas 12 y 52 (pág. 539-573), pág. 567.

54 AASF: Comisión de Arquitectura. Informes, 1788-1797. Leg. 1-28/1. Oficio de Antonio Ponz dirigido a José Moreno, fechado el 11 de marzo de 1790, indicándole que para la Junta del 30 de marzo le remite un expediente con tres dibujos y carta de José de Ávalos para realizar una silleria en la Capilla de San Fernando.- Oficio de Antonio Ponz dirigido a José Moreno, fechado el 8 de junio de 1790, dándole cuenta de los expedientes que le remite para ser examinados en la Junta de la Comisión de Arquitectura del 12 de junio. Entre ellos uno de cuatro dibujos para una silleria, facistol y otros adornos de la Capilla Real de Sevilla ejecutados por el académico Antonio Fernández Bertoni. El expediente fue devuelto por Moreno el 15 de junio de ese mismo año.

55 AASF: Actas, obra citada, Leg. 3/139. Junta núm. 199 del 28 de febrero de 1805, fol. 391 reverso. Aprobación de los diseños de Antonio Aguado para un altar para la Capilla de los Dolores junto a la Sacristía de los cálices en la Catedral de Sevilla. Acta firmada por Silvestre Pérez. También en acta del 30 de marzo de 1805. José HERnANDEz Diaz, "Retablos y esculturas", obra citada, en nota 52, pág. 306. 
de ellos se relaciona con la idea de construir una sillería. Las actas de la Junta del día 17 de marzo de 1787 se refieren al envío por parte del Secretario Antonio Ponz de tres dibujos. Dos de ellos eran copia de la sillería del coro de El Escorial y el tercero un proyecto de Alfonso Regalado Rodriguez para que la Comisión de Arquitectura diera su dictamen. En este sentido se acordó contestar al apoderado de esa Catedral "diciendo que si no había gusto o motivo particular en hacer la sillería del Escorial podría llevarse a efecto la del Señor Regalado que era arreglada" ${ }^{56}$.

El otro documento relacionado con el templo catedralicio murciano se trata de un oficio de Antonio Ponz dirigido a José Moreno para que la Junta de la Comisión de Arquitectura diera su parecer sobre los dibujos realizados por el Director Manuel Martín Rodríguez para hacer un Tabernáculo en la Capilla Mayor y otros altares de esta Catedral. Lleva fecha del 27 de junio de $1788^{57}$.

\section{El baptisterio de la Catedral de Palma de Mallorca}

En el interior de la magnífica catedral de Palma de Mallorca destaca como obra hecha en las postrimerias del siglo XVIII, más concretamente entre 1790 y 1794, su baptisterio. Catalina Cantarellas identificó tal realización con el capuchino ilustrado fray Miguel de Petra (1741-1803), reflejando así su atribución tradicional, aunque esta historiadora no haya podido confirmarla de una forma documentada. No obstante, parece ser que el Obispo Rubio convocó para ello un concurso, al cual se presentaron varios proyectos.

Sin duda, esta obra destaca más por su mismo carácter decorativo que por la aportación constructiva. Se hubo de partir de un espacio ya dado, rectangular y situado a los pies del templo, detrás de uno de los laterales de su fachada principal. Hay en el baptisterio un cierto grado de simulación, pareciendo casi una arquitectura fingida, pues el elemento

56 AASF: Actas, obra citada, Leg. 3/139. Junta núm. 16 del 17 de marzo de 1787, t. I, fol. 53 anverso.

57 AASF: Comisión de Arquitectura. Informes. 1788-1797. Leg. 1-28/1. Oficio de Antonio Ponz dirigido a José Moreno con fecha del 27 de junio de 1788 sobre los proyectos de Manuel Martin Rodríguez para un Tabernáculo en la Capilla Mayor de la Catedral de Murcia. 
ornamental es prioritario. Sobre una serie de pilastras se superpone un friso, consiguiéndose por medio de la alternancia de los materiales empleados una cierta policromía. El conjunto se completa por medio de seis lienzos pintados por José Camarón, José Vergara y Luis Antonio Planes alusivos al Sacramento del Bautismo, con una serie de medallones y el empleo de estucos. Es posible percibir en el conjunto una gran suntuosidad, que, tal y como Canterellas ha señalado, tiene "escasos resabios pompeyanos" ${ }^{58}$.

\section{El tabernáculo de la Catedral de Salamanca}

Entre los proyectos irrealizados en catedrales góticas españolas de esta época hay que mencionar aqui el de un tabernáculo para el altar mayor de la nueva de Salamanca. Debia sustituir al retablo monumental de Alberto de Churriguera, desmontado por no acomodarse al nuevo gusto. La obra fue encomendada, al parecer, a Ventura Rodríguez, quien fallecería sin hacerla, heredando el encargo su sobrino Manuel Martín Rodríguez. A finales del año 1790 concluyó el diseño con el uso de un lenguaje tan sobrio como clásico, pensándolo en forma de templete de orden corintio. La Real Academia de Bellas Artes de San Fernando aprobó dicho proyecto en la Junta de la Comisión de Arquitectura del 11 de febrero de 1791, de la que Pedro Arnal, Manuel Machuca, Ramón Durán, Ignacio Haan, Ramón Alonso y José Moreno, como secretario, formaron parte, manifestándose en las Actas el agrado producido por la obra debido a su "esmero y buen gusto"; pero también se propuso que fuera colocado en medio del crucero, trasladándose el coro a la Capilla Mayor, idea que no era del agrado del Cabildo. La parte escultórica se debe a Juan Adam y a Alfonso Bergaz, mientras que el modelo en ma-

58 Catalina Cantarellas CAMPS, La arquitectura mallorquina desde la llustración a la Restauración. Palma de Mallorca, Institut d'Estudis Baleàrs, 1981, pág. 160.-- Jerónimo JUAN TOUS, "El Baptisterio de nuestra Catedral", en Boletin de la Sociedad Luliana, t. XXXIII. Palma de Mallorca, 1968-1972, pág. 620. 
dera, que se conserva, fue ejecutado por Domingo Dalli. Se pensaba realizarlo empleando mármoles y bronces ${ }^{59}$.

\section{Obras en la Catedral de Ávila}

En las actas de la Comisión de Arquitectura de la Real Academia de Bellas Artes de San Fernando de los días 27 de junio y 23 de agosto de 1786 se rechazó por considerarse inadecuado el proyecto del escultor académico José Rodríguez Díaz, remitido el 9 de junio por Fernando Bergas Solerzano ${ }^{60}$, para hacer un segundo cuerpo de madera de orden compuesto al trascoro corintio de la Catedral de Ávila. En la reunión que tuvo lugar en esa primera fecha se descalificó el dibujo por faltar el del primer cuerpo, al cual se debía añadir, y en lo referente a la forma porque «se hallaron en el pensamiento varios defectos de mal gusto y poca inteligencia de las reglas de la buena arquitectura", decidiéndose "decir con lisura, sin embargo de ser invención de un individuo de la Academia, pues ni al Cuerpo ni al Individuo le puede resultar desdoro que no se apruebe una obra en facultad de que no es Profesor reconocido". En esta misma línea se hallan el Informe de dicha Comision del 28 de junio, firmado por José Moreno, y la respuesta en nombre de la Academia a la carta del Deán Pedro Gallego y Figueroa, si bien ahora el documento es más explicito, señalándose como otro defecto el resultar muy anchos los espacios entre las pilastras y que «el partido de las pilastras angulares en ángulo obstuso es malo, porque las hace parecer de la mitad del ancho de las otras".

Como el Deán de esta Catedral insistiera, remitiendo a Antonio Ponz, como Secretario de la Academia, el 22 de julio de ese año de 1786 el

59 Fernando Chueca Goitia, La Catedral Nueva de Salamanca, obra citada en nota 11, pág. 195.- Pedro NAvascues, “La formación de la arquitectura clásica", pág. 675.AASF: Actas de la Comisión de Arquitectura. Leg. 3/139. Acta de la Junta del 11 de febrero de 1791, firmada por José Moreno. Aprobación del diseño de Manuel Martín Rodriguez para el tabernáculo de la Catedral de Salamanca.- AASF: Leg. 1-28/1. Carta oficio de José Moreno, fechada el 20 de febrero de 1791, indicando al Secretario de la Academia la devolución de este expediente.

60 AASF: Actas de la Comisión de Arquitectura. Leg. 3/139. Junta núm. 4 del 27 de junio de 1786, fol. 36 reverso. Acta, firmada por José Moreno, sobre los dibujos del académico escultor Josef Rodríguez Díaz para un segundo cuerpo de madera en el trascoro de la Catedral de Ávila. 
dibujo y descripción del primer cuerpo, esta Junta volvió a reprobar el 23 de agosto la idea de Rodríguez Díaz porque «la Arquitectura Romana de su segundo cuerpo de ningún modo puede convenir con la Arquitectura ideal, llena de partes y figuras menudísimas de que consta el cuerpo primero". Añadiéndose en el correspondiente informe de José Moreno otra causa a esta denegación del permiso de construir: "porque la seriedad y partidos magestuosos de ésta (se refiere a la arquitectura romana) lejos de dar buen aspecto al todo del trascoro, causarían una discordancia ridicula que gritaría siempre contra la poca inteligencia o el mal gusto de los que permitieron construírlo" ${ }^{6 !}$.

Esta resolución de la Academia resulta realmente interesante por varios motivos: en primer lugar porque la Junta no deseaba aprobar un proyecto arquitectónico realizado por un escultor, aunque les intimidara el hecho mismo de que éste fuera además académico, y porque en el dictamen parece existir una cierta contradicción entre una y otra resolución, pues, sí en las primeras actas se desestimó el dibujo por no acomodarse a las reglas del buen gusto, en las siguientes se le rechazó por no ser dicho proyecto adecuado al cuerpo existente. No obstante, es verdad que entonces tal Comisión ya contaba con un diseño de la obra primitiva con el que hacerse una opinión más exacta. Pero lo fundamental es la idea de que mientras subsistiera el primer cuerpo, el segundo añadido debería acomodarse a su estilo.

Juan Antonio Cuerbo, arquitecto avecindado en Madrid, realizó en la última década del siglo XVIII varias obras en la Catedral de Ávila. Su presencia en esta ciudad se documenta en 1791. Allí concluyó la Capilla de los Velada, proyectó la terminación de la de Nuestra Señora de la Blanca e hizo tres diseños para el aguamanil de la sacristía y otro a fin de reformar la torre. La construcción del aguamanil, encargada por el Cabildo, le obligaría a trazar consecutivamente tres dibujos en el verano de 1792, que se acomodaban a distintas dimensiones. El primero, el más reducido por tener que acoplarse a un espacio muy pequeño en el muro

\footnotetext{
${ }^{61}$ AASF: Actas de la Comisión de Arquitectura. Leg. 3/189. Junta núm. 8 del 23 de agosto de 1786, fol. 41 anverso. Reprobación del proyecto de José Rodriguez para la realización de un segundo cuerpo en el trascoro de la Catedra de Ávila. También: A.A.S.F.: Informes de la Comisión de Arquitectura. 1758-1815. Leg.: 1-28/5. "Respuestas de José Moreno, Secretario de la Comisión de Arquitectura de la Academia de San Fernando al Deán D. Pedro Gallego y Figueroa de la Catedral de Ávila, fechadas en Madrid, el 8 de julio y el 24 de agosto de 1786. En este mismo Legajo 1-28/5 se halla la carta de Fernando Bergas Solerzano, apoderado de la Catedral de Ávila, datada en Madrid el $\mathbf{9}$ de junio de 1786, indicando que remite el plan de reformas proyectadas para la Catedral de Ávila a fin de que la Academia dictamine sobre él.
} 
izquierdo de la sacristía, se empotraba en él, colocándose el jarrón rematado por el escudo catedralicio en una hornacina y encima de la pila sostenida por un balaustre. El segundo, muy clásico y sin duda el más costoso, constaba de un tetrástilo trabajado en piedra de las canteras del Puchero con tres jarrones de mármol en los intercolumnios, rematándose el entablamento por medio de un frontón semicircular en cuyo centro se colocaba en yeso el escudo de la Catedral. La solución final fue una variación de este proyecto intermedio, pues entre las finas pilastras se colocaba una sola pila y simplificaba dicho frontón ${ }^{62}$.

\section{Transformaciones en el interior de la Catedral de Toledo}

Las transformaciones hechas en el interior de la Catedral de Toledo durante la segunda mitad del siglo XVIII son muy numerosas. Las reformas principales fueron promovidas por el ilustrado Cardenal don Francisco Antonio de Lorenzana, quien sucedió a don Luis Fernández de Córdoba como Arzobispo, que lo habia sido entre 1754 y 1771, y se continuarian hasta la Guerra de la Independencia bajo el Arzobispado de don Luis María de Borbón. Así, resulta bastante raro el no hallar una capilla que no contenga esculturas y pinturas realizadas entonces o nuevos retablos de formas más depuradas y ricos materiales en sustitución de otros barrocos y hasta góticos alejados del clasicismo. En la catedral toledana intervinieron, dada su importancia y la proximidad de Madrid y de la Academia de San Fernando, muchos de los artistas más significativos de la época. Arquitectos como Ventura Rodríguez, López Durango e Ignacio Haan, los escultores Francisco Álvarez, Juan Pascual de Mena y Mariano Salvatierra y los pintores Maella y Bayeu trabajaron para este templo. Por consiguiente, no se puede hablar de que grandes cambios afectaran a estas capillas de Santa Lucia, de los Reyes Nuevos, de San Ildefonso, de San Pedro y de Santiago; sino de simples reformas parciales, que no alteraron a las estructuras arquitectónicas de otros estilos.

Ventura Rodríguez, en su calidad de arquitecto mayor de la Catedral de Toledo, diseñó y ordenó una serie de retablos de líneas muy sencillas

62 Documentos para la Historia de Ávila. Ávila, museo provincial, diciembre 1985-enero 1986. Ávila, Centro Asociado en Ávila de la UNED, 1985. Ficha firmada por J. G. comentando planos y dibujos del Archivo de la Catedral. Ávila. Planos y dibujos. 25 de julio y 13 de septiembre de 1792. Véase estudio de M. Pilar Aumente, Juan Antonio Cuerbo. Sus obras en Ávila. 
y realizados con el empleo de ricos materiales como el mármol y el bronce, adecuándose asi a las imposiciones sobre retablística de la carta circular de Carlos III de 1777. Precisamente en ese mismo año proyectó tres de ellos en el primer tramo de la Capilla de los Reyes Nuevos, obra hecha por Alonso de Covarrubias entre 1531 y 1534 para que sirviera de Panteón a los Trastamaras. Estos altares se adornaron con lienzos pintados por Mariano Salvador Maella (1739-1791), que respectivamente representan el Nacimiento de Jesús, la Epifanía y el Apóstol Santiago ${ }^{63}$.

El arquitecto de Ciempozuelos también dirigió hacia 1780 la construcción del magnífico retablo corintio y de un sólo cuerpo de la Capilla de San Ildefonso, que se eleva sobre cuatro gradas de mármol en el centro de la cabecera y frente al sepulcro del Arzobispo y Cardenal don Gil Álvarez Carrillo de Albornoz, fallecido en 1364 (lam. XXXV). El uso de varios materiales nobles contribuyen a dotarle de una magnífica policromía, pues los jaspes de diversos colores se alternan en él con el bronce dorado de las estrías de los fustes, capiteles y basas de las dos grandiosas columnas, que encuadran al medallón cuadrilongo. Allí se representa en medio relieve la escena de la Imposición de la casulla a San Ildefonso por la Virgen, esculpido en 1783 por Manuel Francisco Álvarez (1727-1797), Director de la Real Academia de Bellas Artes de San Fernando. Las figuras de alabastro de San Leandro y San Isidoro de las dos puertas de madera existentes a los lados del altar fueron realizados por Juan Pascual de Mena (1707-1784), mientras que a Manuel Jiménez se deben los bronces ${ }^{64}$.

Durante el arzobispado del Cardenal Lorenzana (1728-1804) se emprendieron varias reformas en el interior de la Catedral de Toledo. Así sucedió en la capilla gótica de una sola nave y tres tramos dedicada a San Pedro, que habia sido construida en los tiempos del Arzobispo don Sancho de Rojas a principios del siglo xIv. Tal reestructuración comprendió la retirada de una serie de retablos, como los de San Francisco Javier y San Ignacio de Loyola, sustituidos por otros dos nuevos bajo la advocación de estos mismos Santos, y la construcción del altar mayor de un solo cuerpo y de mármol obtenido de las canteras almerienses de Macael. Contiene un grandioso cuadro pintado por Bayeu, que representa el milagro de la curación del paralítico por San Pedro y se remata con un

63 Sixto Ramon Parro, Toledo en la mano, v. I, pág. 403. En la acta del 30 de noviembre de 1803 de la Comisión de Arquitectura de la Academia (AASF: Leg. 139-3) se aprobó un diseño para la construcción de un altar en la Capilla de los Reyes Nuevos de la Catedral de Toledo, presentado por el arquitecto académico Mateo Medina.

64 Ibídem, v. I, pág. 357-357. Capilla de San Ildefonso: pág. 346-370. 
grupo de ángeles que sostienen los atributos pontificios, esculpido por Mariano Salvatierra entre 1785 y 1788 . El sepulcro del fundador también se quitó del centro de la capilla, colocándose en una hornacina en el muro del lado del Evangelio. En el segundo tramo se construyeron otros cuatro retablos realizados en ricos mármoles, que recibieron otros lienzos de este artista aragonés, en donde se representan a San Pedro, Obispo de Osma, y a San Julián, quien to fue de Cuenca ${ }^{65}$.

El Cardenal Lorenzana encargó a Mariano Salvatierra para reformar la Capilla de Santiago que esculpiera en piedra una serie muy interesante de ocho Santos. Estas estatuas, comenzadas en 1791, se hicieron a fin de sustituir los retablitos de los muros. De tamaño casi natural fueron colocados sobre bellas repisas junto a los pilares y sin que sus formas deslucieran del conjunto arquitectónico. Con el empleo de un lenguaje barroco clasicista el escultor representó a San Nicolás de Bari, San Antonio Abad, San Francisco de Asís y San Pedro Nolasco en el lado del Evangelio y en el de la Epistola a San Felipe Neri, Santa Bárbara, San Lorenzo y San Bernardo, destacando en ellas el dinámico plegado de los ropajes ${ }^{66}$.

Precisamente en este mismo año de 1791, más en concreto el 15 de abril, la Junta de la Comisión de Arquitectura de la Real Academia de Bellas Artes de San Fernando aprobó un dibujo para el órgano nuevo de esta Catedral, hecho por el académico Blas Cesáreo Martin ${ }^{67}$.

Según Sixto Ramón Parro dice en su libro Toledo en la mano ${ }^{68}$, Ignacio Haan, discípulo de Sabatini y viajero por Roma en donde convivió con Ortiz y Sanz, proyectó por encargo del Cardenal don Luis de Borbón el revestimiento de mármoles de los cuatro muros del Salón de la Sacristía de la catedral toledana, tal y como se hizo en la capilla del Sagrario y el Ochavo. Pero esta obra no se realizó debido a los distintos aconte-

65 Ibídem, v. I, pág. 487. Capilla de San Pedro: pág. 487-505.

66 Ibídem, v. I, pág. 370-390 (Capilla de Santiago). Juan Nicolau CASTro, "Mariano Salvatierra Serrano, escultor de la Catedral de Toledo". Goya núm. 204. Madrid, mayojunio 1988, pag. 337-342. Vid. pág. 340. También Juan Nicolau CASTRO: “Obras del siglo XVIII en la Catedral de Toledo", Anales Toledanos, XIX, 1984.

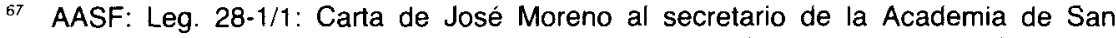
Fernando notificándole la devolución de los expedientes de los proyectos tratados en la Junta de la Comisión de Arquitectura del 8 de abril de 1971. Se aprobó un dibujo para el órgano nuevo de la Catedral de Toledo hecho por el académico Blas Cesáreo Martín. Sobre el órgano diseñado por Ventura Rodríguez: Juan NicolaU CASTRO, "Ventura Rodríguez y el órgano neoclásico de la Catedral de Toledo". Estudios sobre Ventura Rodriguez, obra citada, pág. 139-145.

gb Sixto Ramon Parro, Toledo en la mano, pág. 537-538. 
cimientos de la Guerra de la Independencia. No obstante, en su frente principal en el testero norte se conserva un espléndido altar mayor suyo de orden corintio hecho en ricos mármoles adornados con bronce y con otros dos colaterales de dimensiones menores, que reflejan con fidelidad los postulados de la carta circular de Carlos III de 1777 dirigida a las jerarquías eclesiásticas. El famoso cuadro «El expolio» de El Greco se instaló en el centro. La obra escultórica de tales retablos, una serie de representaciones de ángeles, fue esculpida por Mariano Salvatierra ya entre 1800 y 1805 , descatando en ella el bello conjunto de alabastro de la Exaltación de la Cruz, que remata dicho altar mayor, en donde dos ángeles de tamaño natural sostienen una cruz dorada sobre unas nubes.

En las actas de la Comisión de Arquitectura de la Academia de San Fernando de los días 3 y 30 de noviembre de 1803, firmadas por Silvestre Pérez, se incluyen la aprobación y confirmación "por su regularidad y bellas proporciones" del diseño del arquitecto académico Mateo Medina para la construcción de un altar dedicado a San Ildefonso en la Capilla de los Reyes Nuevos de esta Catedral de Toledo ${ }^{69}$.

\section{La denuncia de Joaquín del Camino de las obras del interior de la Catedral de Lugo}

Los incidentes, que el incumplimiento de las Reales Cédulas, obligando a los arquitectos a enviar a la Real Academia de Bellas Artes de San Fernando los proyectos de todas las obras a realizar, siguieron ya en los inicios del siglo xIX. Una de las polémicas más importantes tuvo como protagonista a Melchor Prado y Mariño, académico de mérito de esa institución, desde 1796, quien entonces estaba concluyendo o en vías de concluir tres grandes retablos de madera, un pequeño altar, una caja de órganos, labores de enrejado del coro y una capilla en el claustro para sepultura del Obispo y de los canónigos de la Catedral de Lugo.

El 6 de mayo de 1804 el canónigo Joaquín Antonio del Camino denunció estas obras, hechas sin el permiso de la Academia, en una carta

69 ASSF: Actas de la Sección de Arquitectura. Desde 1786 hasta 1805. Leg.: 3/139, fol. 369 reverso. Acta núm. 185 de la Junta del 30 de noviembre de 1803 . Aprobación del diseño de Mateo Medina para la construcción de un altar en la Capilla de los Reyes Nuevos de la Catedral de Toledo. También en Acta de la Junta núm. 186, fol. 371 reverso. 
dirigida a Isidoro Bosarte como su Secretario, por atentar contra el «decoro" y la "magestad" del templo. En ella se describe con minuciosidad cada una de ellas con la aportación de su juicio personal. Así, aunque consideraba a los dos nuevos retablos dedicados a San José y a Santa Lucía, "bien organizados al parecer según las proporciones del orden corintio", censuró su situación en el mismo paso del trascoro de la Capilla Mayor, zona poco espaciosa, obscura y baja. Este hecho provocaba que el ático con su grupo escultórico llegase a tocar casi la bóveda y que no se pusieran tarimas, gradas o "escabelos" según pedian los cánones de Vitruvio para todo tipo de altares. Otro aspecto criticado por Camino era la pintura en jaspeado de estos retablos, que no parecían acomodarse a la "lobriguez" del sitio. Las ocho robustas columnas, cuatro por cada altar, eran de un color "sanguineo obscuro" ${ }^{70}$.

Del mismo modo, el tercer retablo tampoco era de su agrado debido a su situación en el trascoro principal y a su gran cantidad de columnas corintias, seis en total, un número mayor que las existentes en el Altar Mayor. También consideraba que el orden arquitectónico empleado no se acomodaba con la estatua, un "Ecce Homo", "muy lastimoso", que se colocaría, pareciéndole más adecuado el uso del dórico. Asimismo criticó su altura desmesurada y el grupo escultórico, que remataria el frontispicio, constituido por un ángel con una cruz en medio de proporciones demasiado robustas y otros dos en los extremos en actitud de adorarla. Camino puso reparos similares al referirse a la caja del órgano de excesiva altura, a los dos óculos colocados a ambos lados del ático y a las rejas del coro y de la Capilla Mayor por ser muy bajas.

Camino se había enfrentado a ciertos sectores del Cabildo en este sentido. Disculpaba al Obispo por no entender nada sobre obras y hacer todo lo que Melchor Prado le decía en la idea de que el arquitecto era académico de San Fernando y de que, además, había trabajado en la Catedral de Santiago. Pero le disgustaba que se estuviera malgastando el dinero, pudiéndose hacer dos retablos «moderados y sencillos, y no disformes y gigantescos como los colaterales de San Josef y Santa Lucía».

Una copia de esta carta fue enviada por Bosarte para su lectura en la Junta particular del 3 de junio; remitiéndose el expediente a la de la Comisión de Arquitectura, presidida por Silvestre Pérez, el día 7 de ese

70 AASF: Catedrales, 1766-1862. Leg.: 2-32, Joaquín Antonio DEL CAMINO: Carta fechada en Lugo el 6 de mayo de 1804 y dirigida a Isidoro Bosarte denunciando las obras que el arquitecto Melchor del Prado realizaba en el interior de la Catedral de Lugo. 
mismo mes, para que informara si había reconocido los planos de todas o algunas de estas obras y su dictamen. Reunida ésta el 8 de julio, se acordó recriminar a Melchor de Prado por no haber enviado los dibujos de las obras emprendidas en la Catedral según exigían las Reales Cédulas, lo que se hizo el 11 de julio. Silvestre Pérez, por su parte, dio cuenta el 16 de la relación de los proyectos del arquitecto que habian sido aprobados por dicha Comisión: un Hospicio en la ciudad de Lugo en las Juntas del 29 de octubre de 1801, 29 de abril, 25 de mayo y 28 de julio de 1802; y tres diseños para la construcción de un Altar Mayor y dos colaterales en mármol de la región en el trascoro de la Catedral de Santiago ${ }^{71}$.

La respuesta de Melchor de Prado, fechada el 1 de agosto de 1804, a) oficio enviado por Bosarte, resulta realmente de gran interés. En ella aceptaba su culpa; pero denunciaba al mismo tiempo una serie de obras, que entonces se hacian en distintas ciudades de Galicia sin la aprobación previa de los dibujos por tal entidad. Se quejaba, así, que mientras que este requisito se les exigían tanto a él como a Fernando Domínguez, únicos arquitectos de ese reino, los "picapedreros y carpinteros, apellidados Arquitectos, tienen amplia libertad para idear, dirigir, y tasar toda suerte de edificios". Terminaba la carta diciendo lo siguientes "Muy difícil será corregir de raíz estos abusos, al menos que no se tome el partido de autorizar en cada provincia un sujeto de confianza, que denuncie al principio las mencionadas obras; pues de esta suerte ni los Cuerpos, ni las personas autorizadas para proyectarlas intentarán construir los edificios clandestinamente como en la actualidad to hacen, sino que con el miedo de ser denunciados, y por no pagar la multa, que se les imponga, obedecerán ciegamente las Ordenes Reales, en que tanto se interesa la Real Academia" 72 .

1 AASF: Catedrales, 1766-1862. Leg.: 2-32/5. Silvesire Perez: Carta dirigida a Isidoro Bosarte, fechada en Madrid el 16 de junio de 1804, notificándole los permisos de obras solicitados por Melchor del Prado en 1801 y 1802.

72 AASF: Catedrales. 1766-1862. Leg: 2-32/5. Melchor DEL PRADO y MARIÑO: Carta dirigida a Isidoro Bosarte fechada en Santiago el 1 de agosto de 1804 contesiándole a su oficio del 11 de julio. 


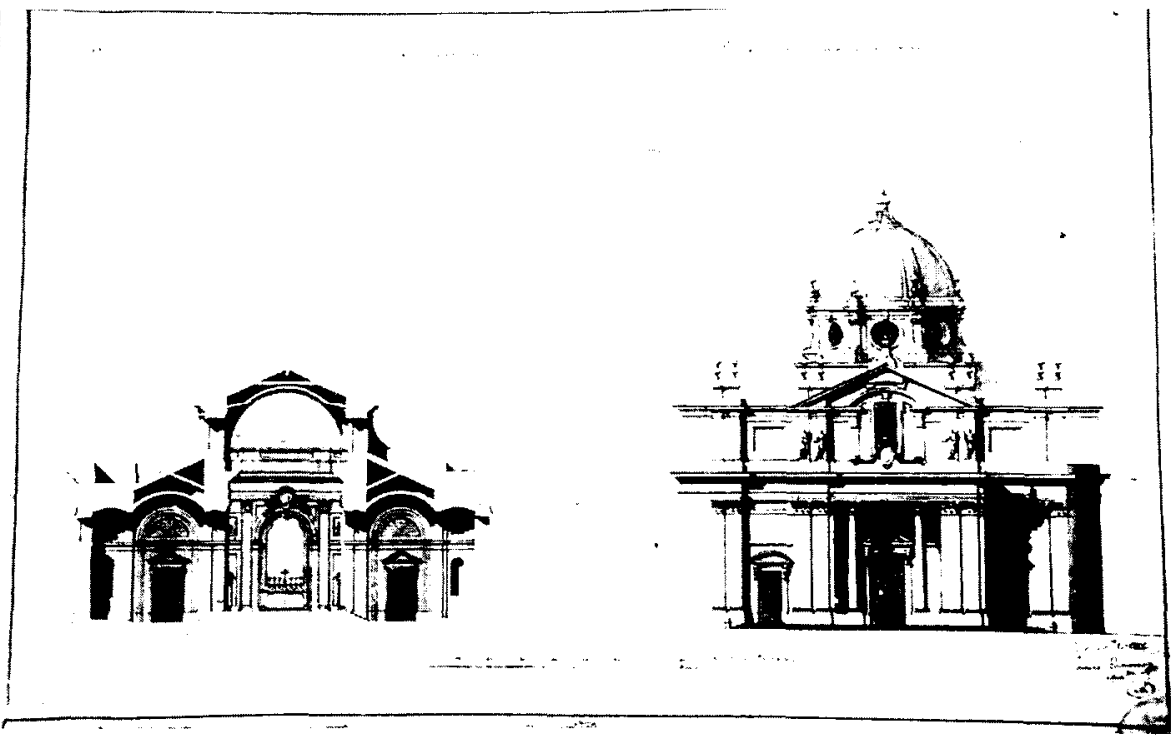

Fig. 1: Catedral de Burgo de Osma (Soria). Alzado y sección de la tachada principal. Proyecto de Ventura Rodriguez. 1 de octubre de 1755. AHN: Consejos, núm. 81

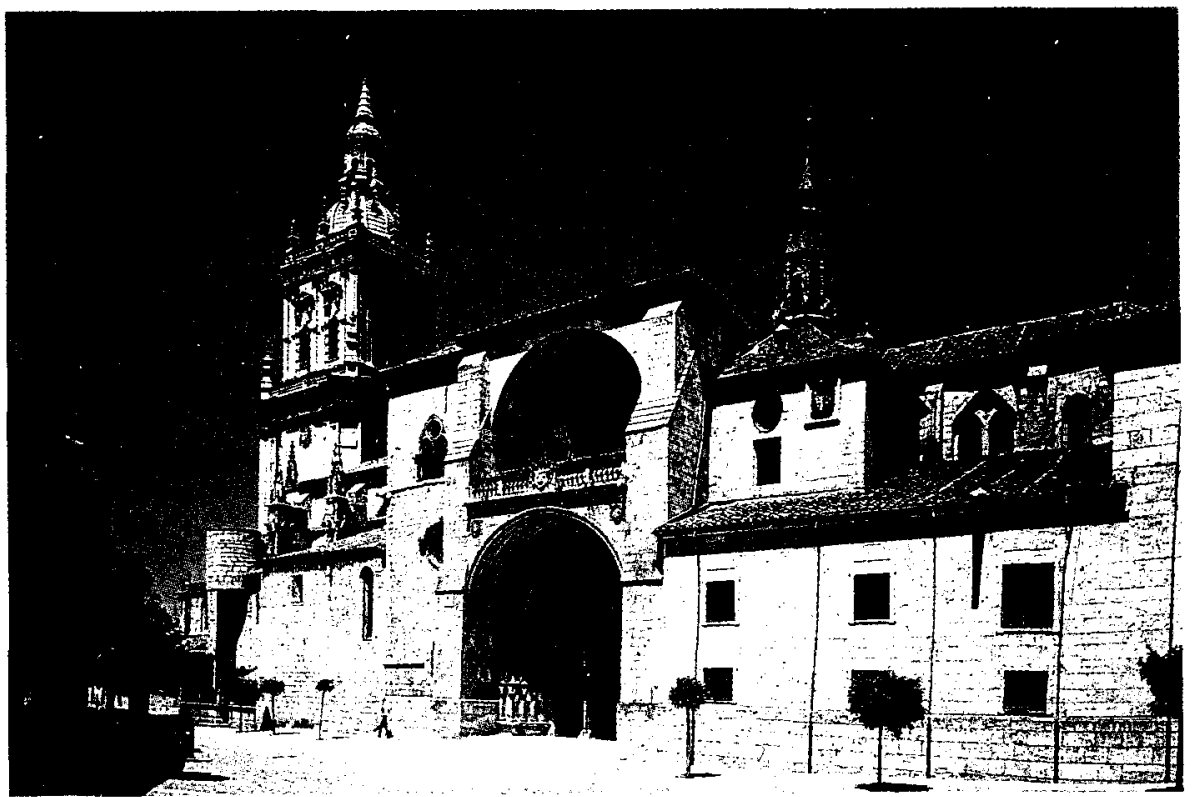

Fig. 2: Exterior de la Catedral de Burgo de Osma (Soria). 
Realizaciones arquitectónicas de la segunda mitad del siglo xvIII..

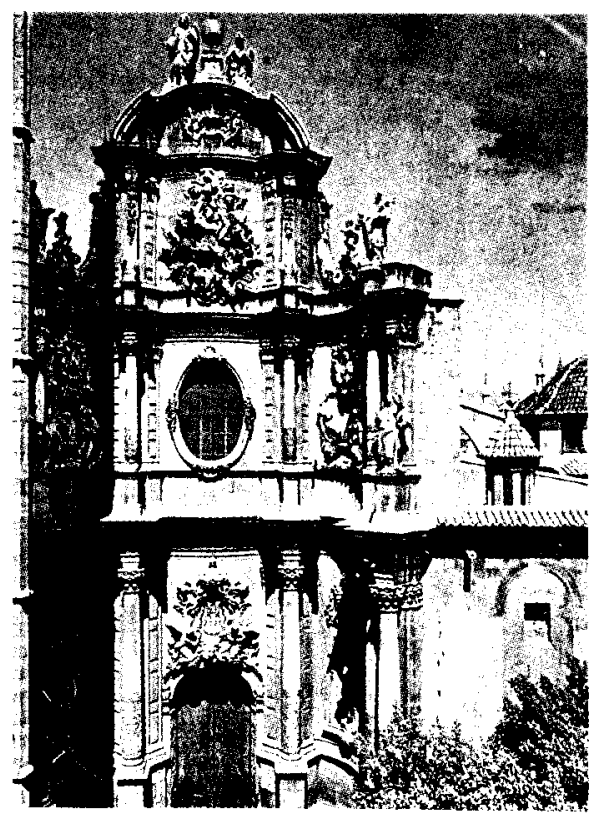

Fig. 3: Fachada principal de la Catedral de Valencia. Conrado Rodulfo. 1703.

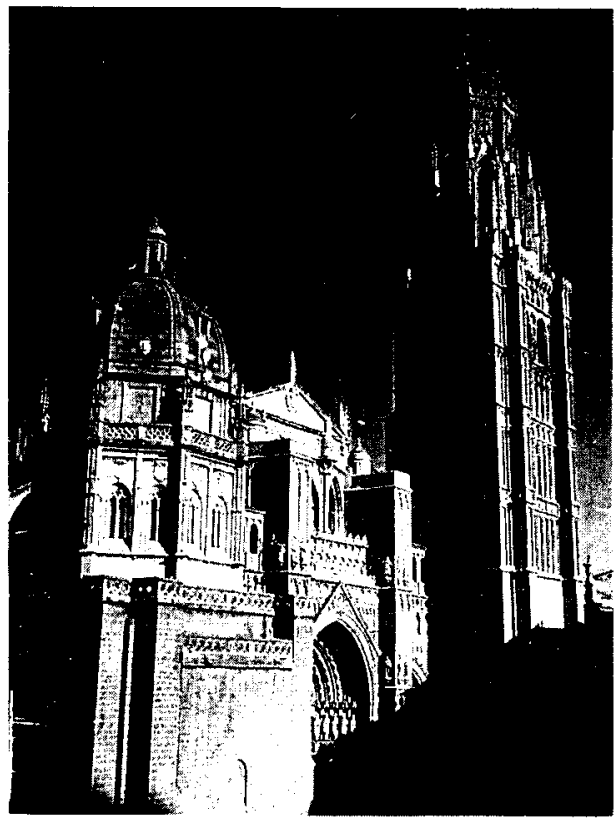

Fig. 5: Catedral de Toledo. Proyecto de la fachada principal por Ventura Rodriguez. 18 de febrero de 1773.

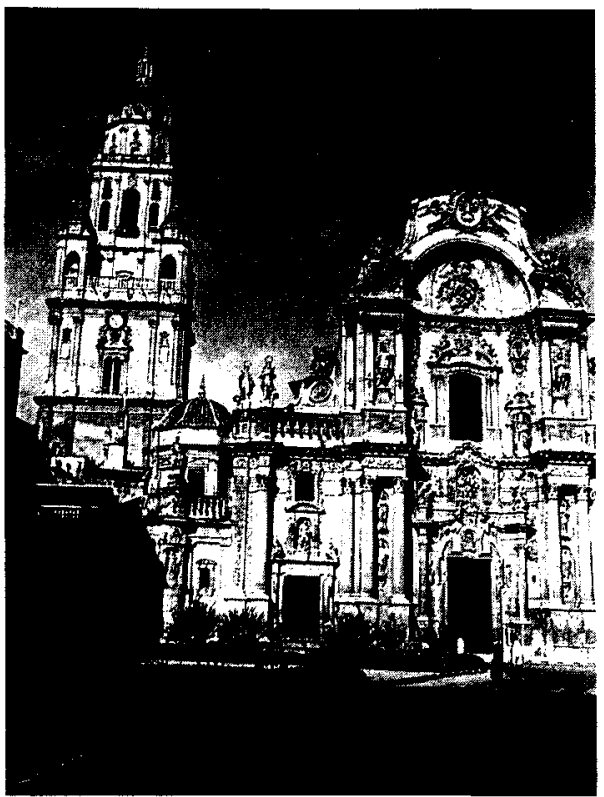

Fig. 4: Fachada principal de la Catedral de Murcia (1731) de Jaime Bort.
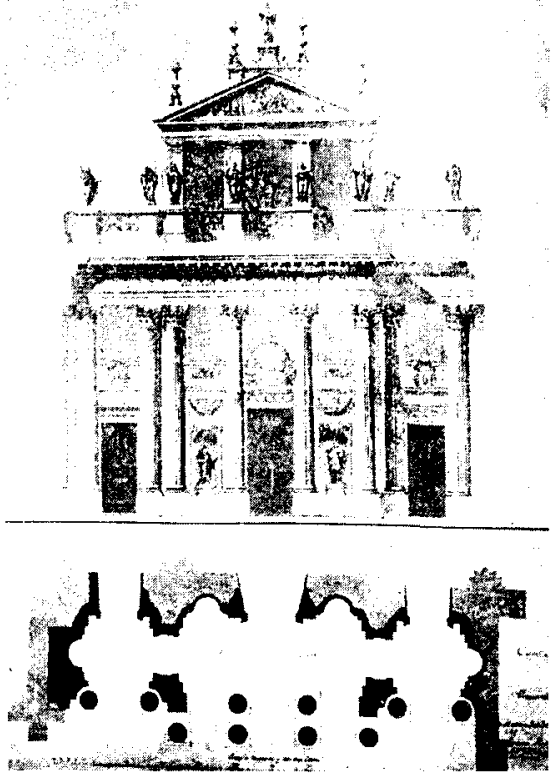

Fig. 6: Catedral de Toledo. Fachada principal. 


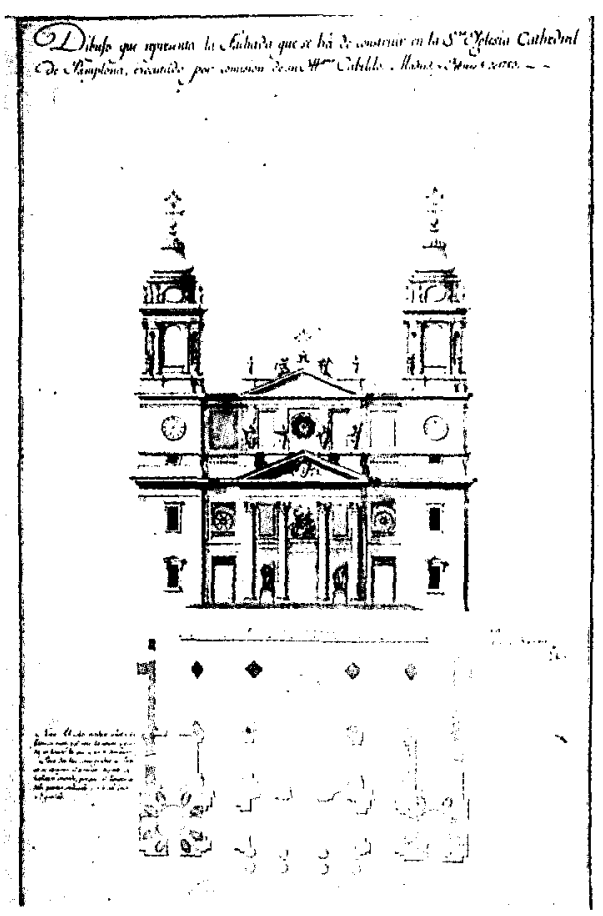

Fig. 7: Catedral de Pamplona. Proyecto de fachada principal por Ventura Rodriguez. Madrid, 5 de febrero de 1785. Museo Diocesano de la Catedral.

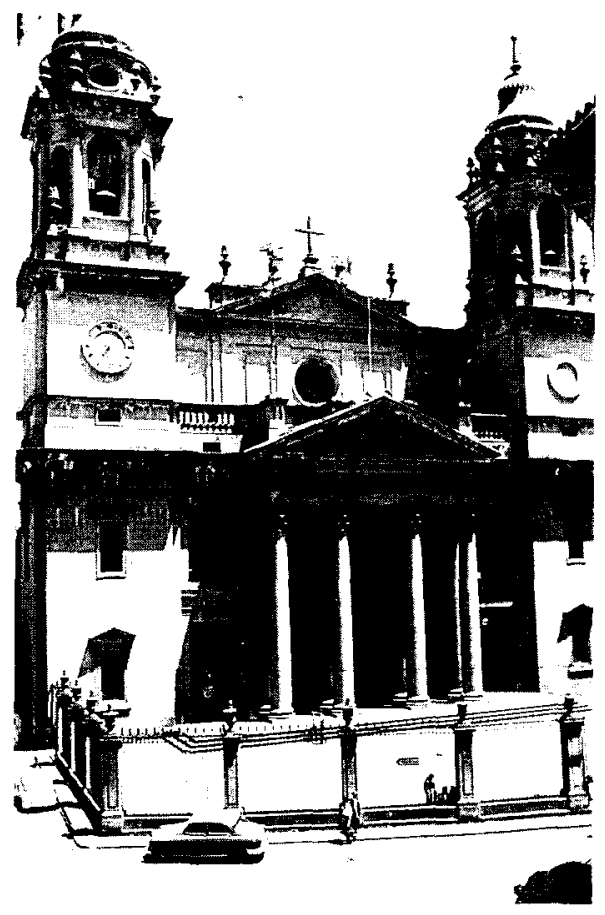

Fig. 8: Catedral de Pamplona. Fachada.

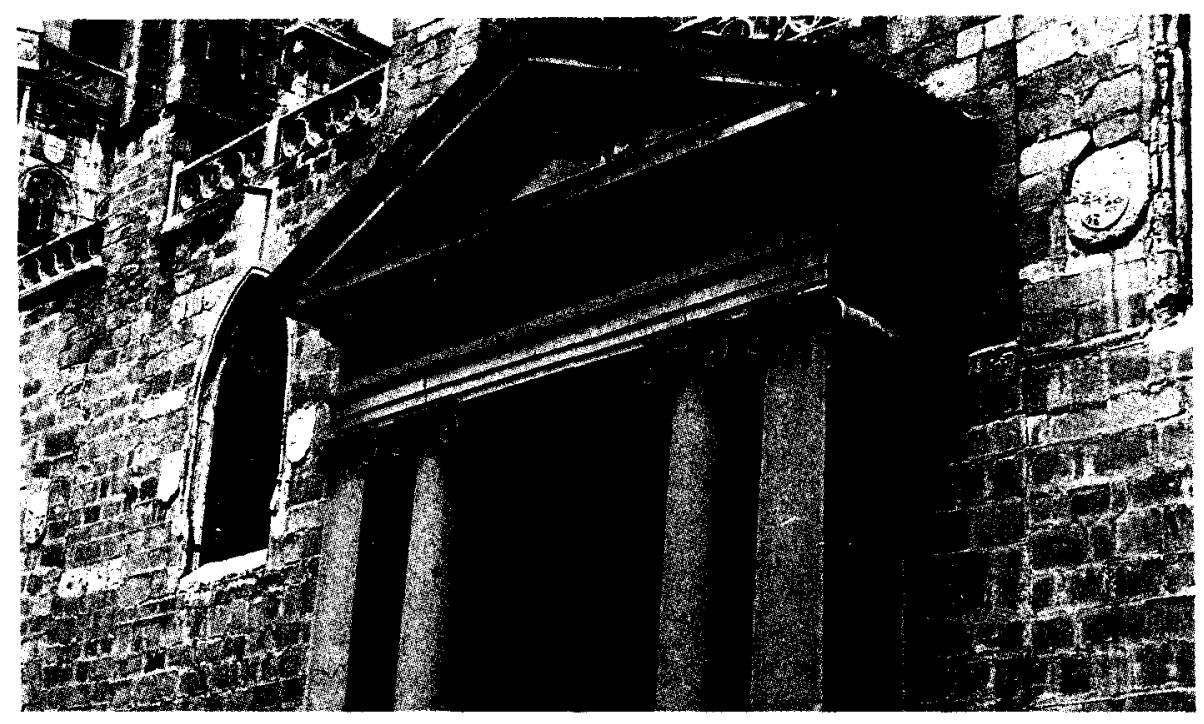

Fig. 9: Catedral de Toledo. Puerta Llana. Ignacio Haan, 1800. 
Realizaciones arquitectónicas de la segunda mitad del siglo XVIII...
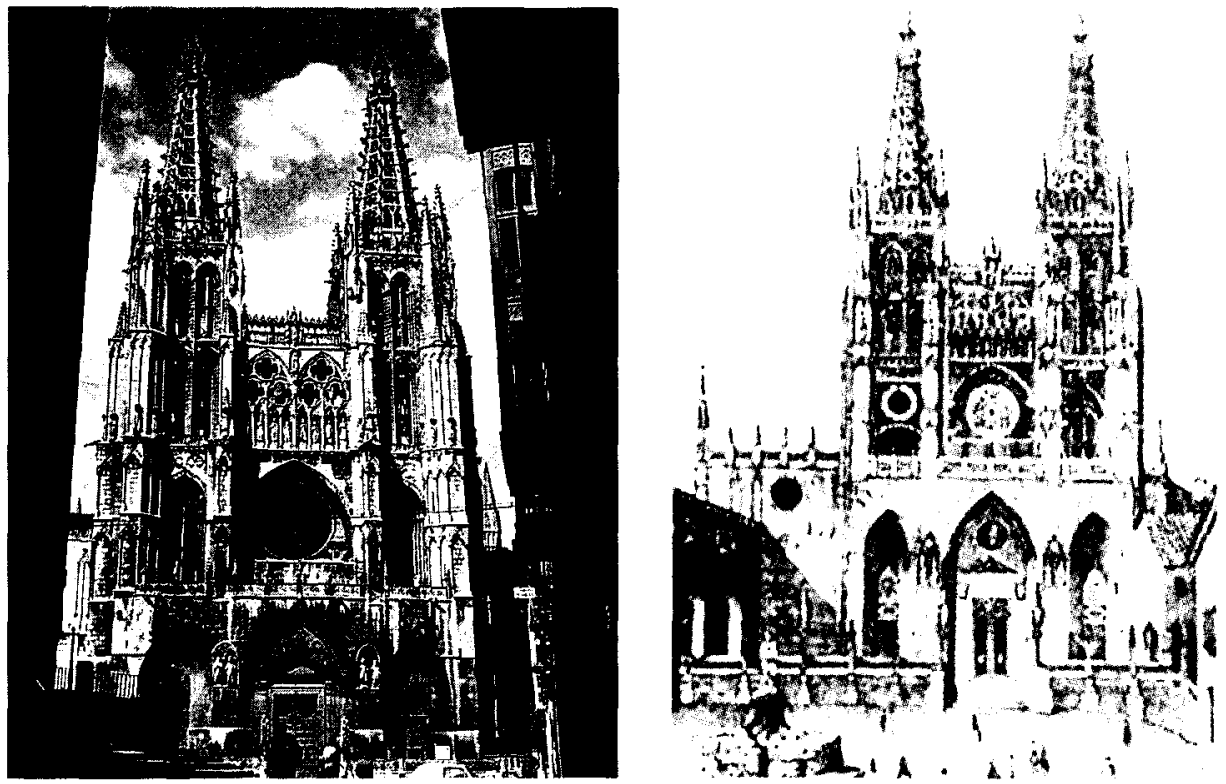

Fig. 10: Catedral de Burgos. Fachada principal

Fig. 12: Catedral de Burgos. La Puerta Real después de la reforma.

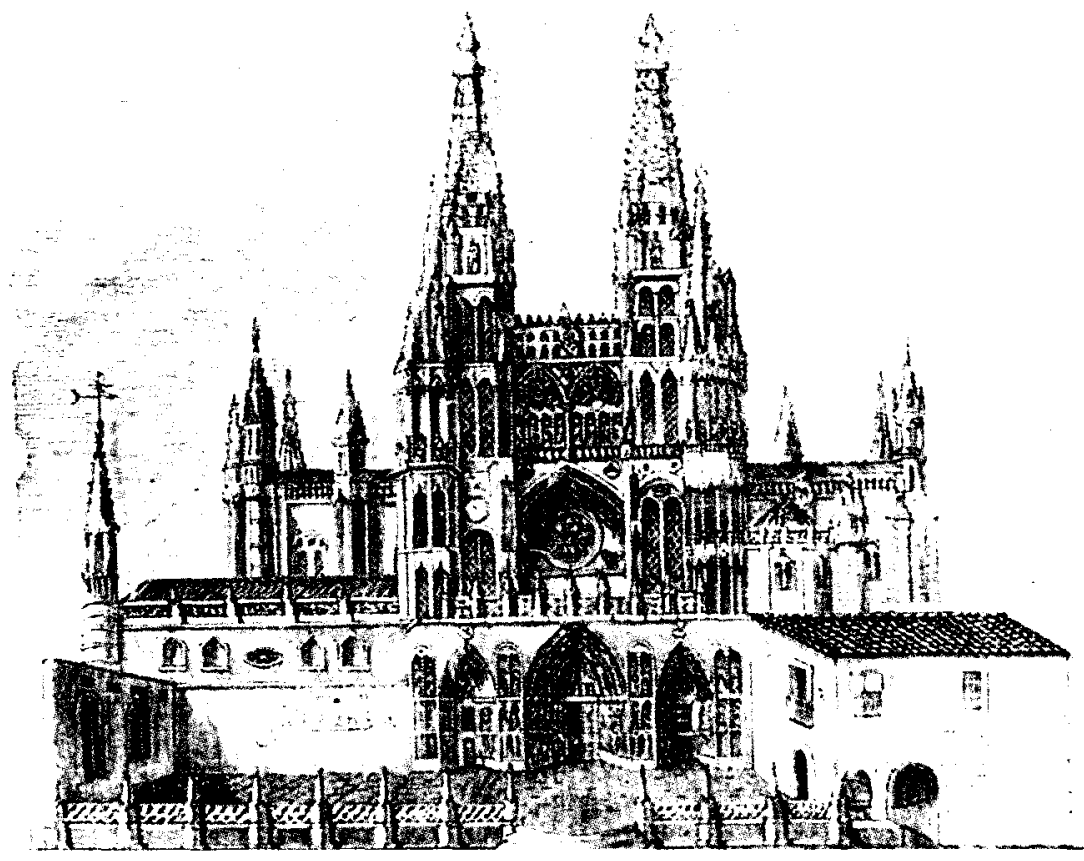

Fig. 11: Catedral de Burgos. La Puerta Real antes de la reforma de 1792. 

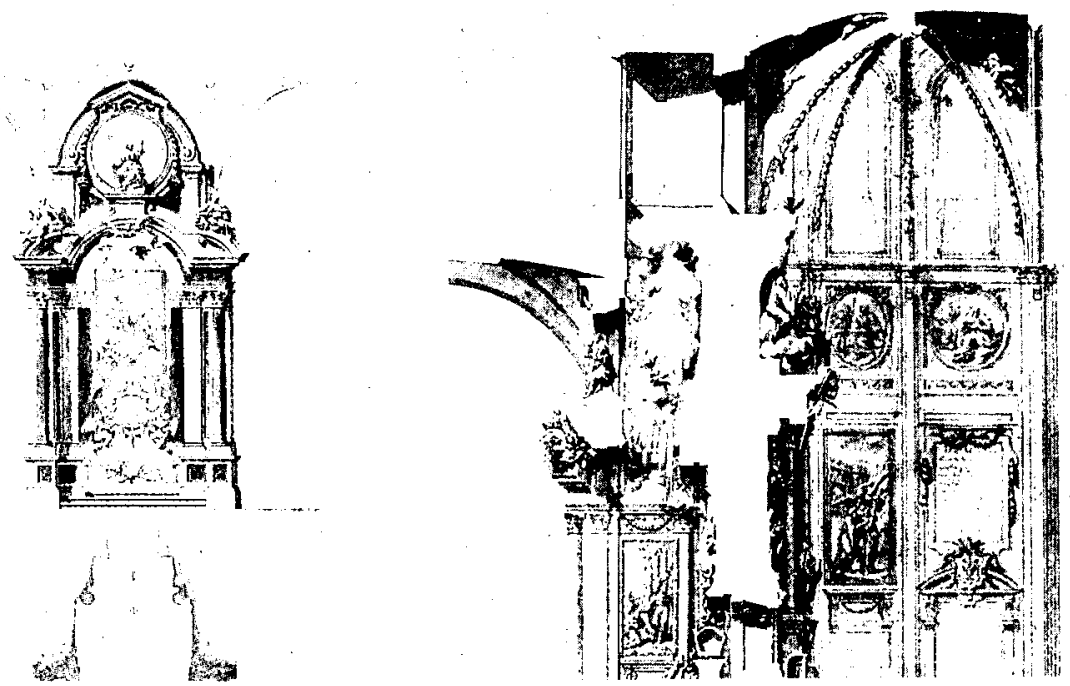

Fig. 13: Catedral de Cuenca. Dibujo de la Capilla de San Julián. Ventura Rodriguez, 4 de septiembre de 1752.

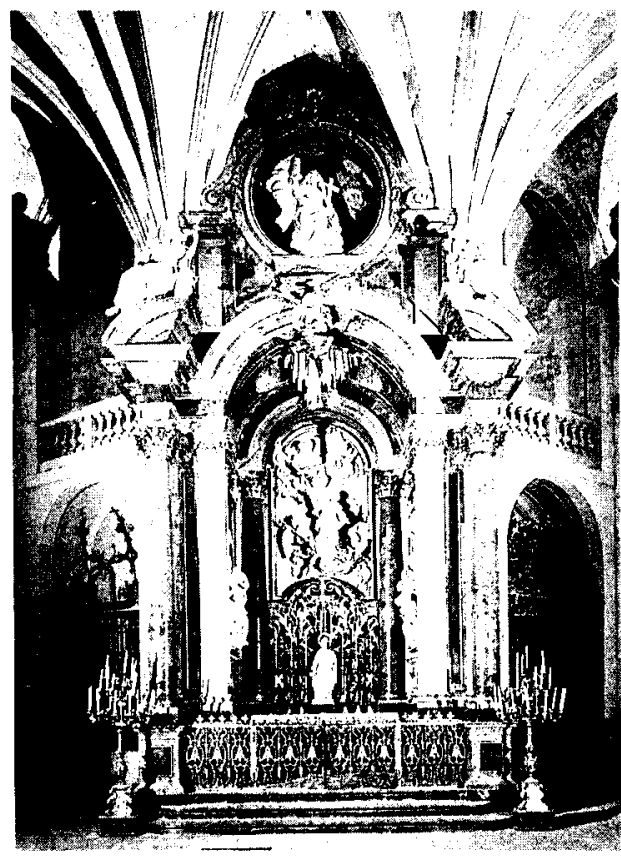

Fig. 15: Catedral de Cuenca. Capilla de San Julián. Ventura Rodriguez, 17521760.
Fig. 14: Catedral de Cuenca. Dibujo de los alzados de la Capilla de San Julián. Ventura Rodríguez, 1752-1760.

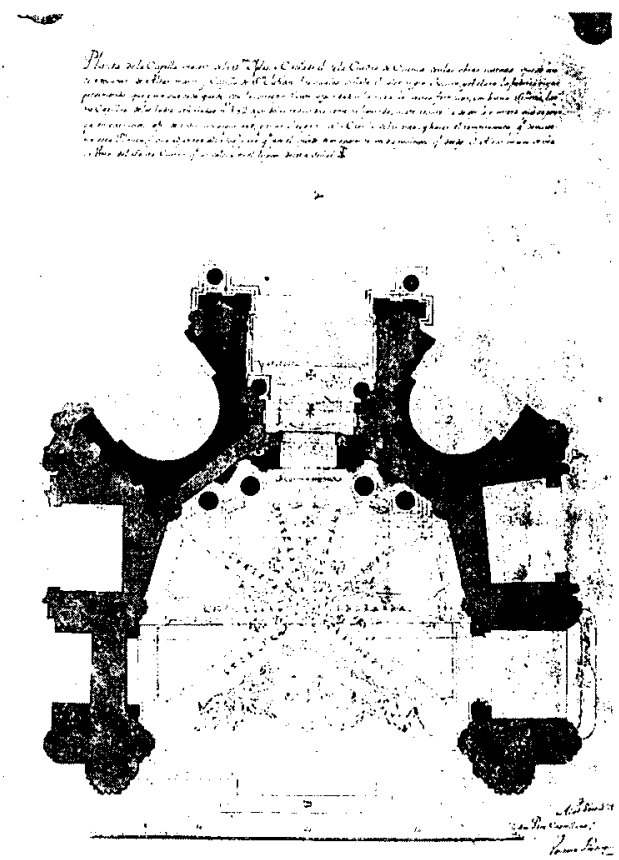

Fig. 16: Catedral de Cuenca. Planta de la Capilla y San Julián y del Altar Mayor. Ventura Rodríguez, 1752. 
Realizaciones arquitectónicas de la segunda mitad del siglo XVII...

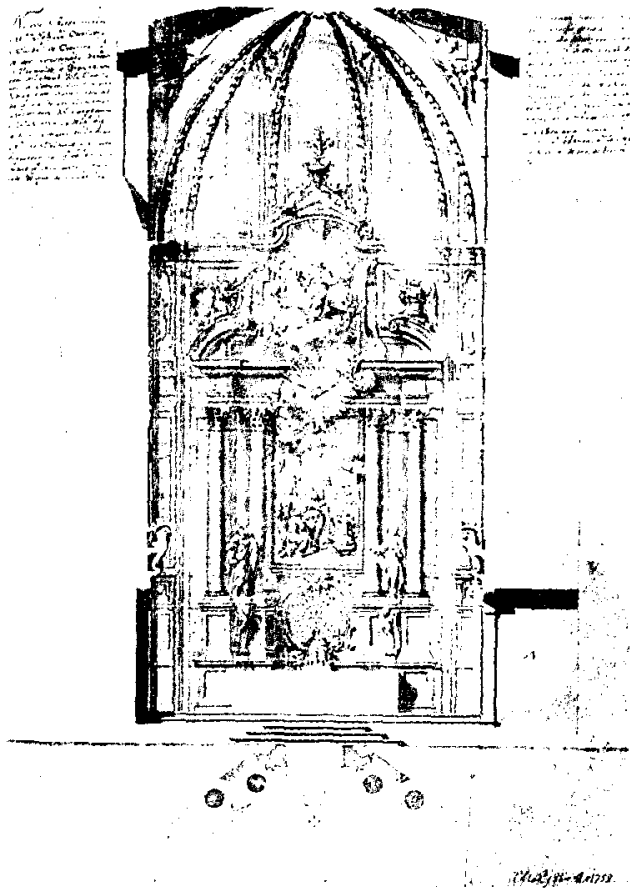

Fig. 17: Catedral de Cuenca. Dibujo del Altar Mayor, Ventura Rodriguez, 1752.

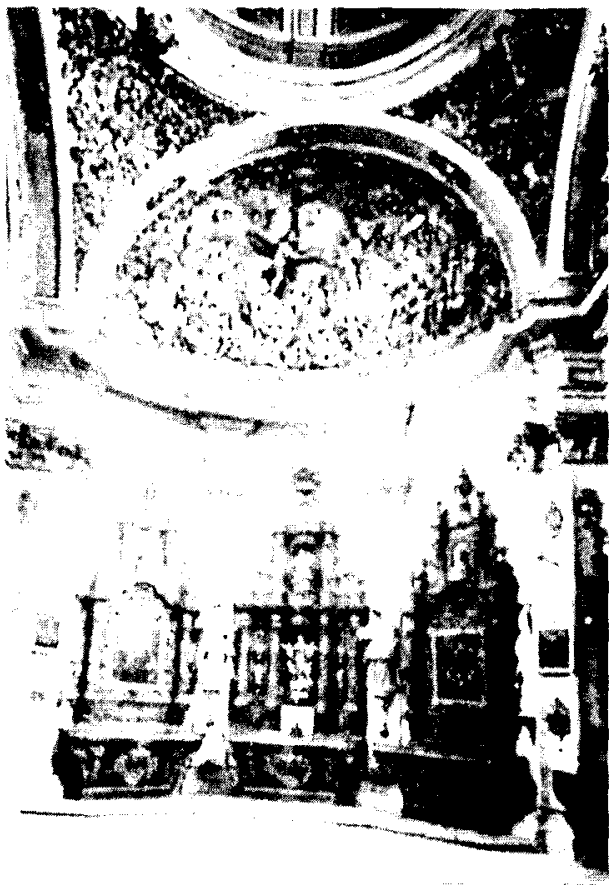

Fig. 18: Catedral de Burgos. Sacristia nueva. Hacia 1761. Proyecto del monje jerónimo Fray Antonio de San José Pontones. Obra dirigida por Fray José de San Juan de la Cruz.

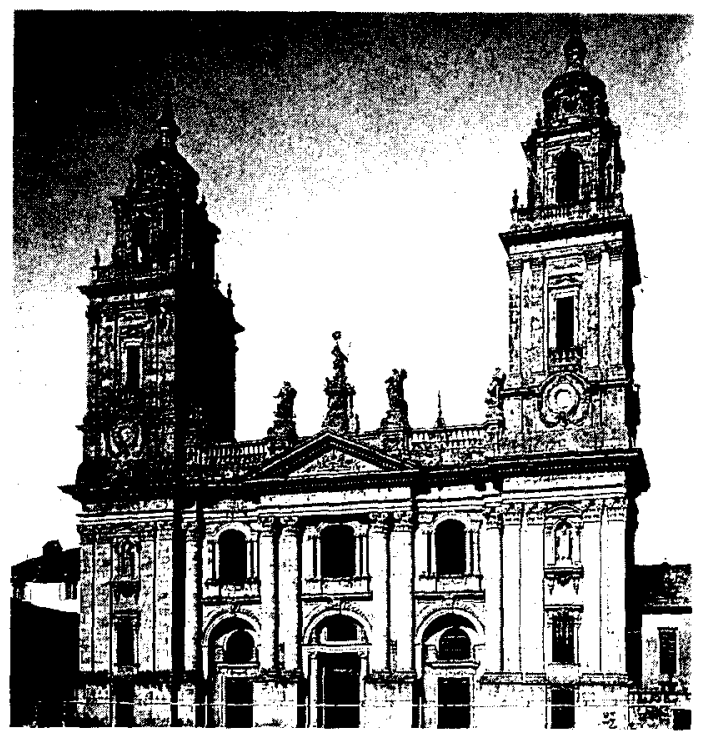

Fig. 19: Catedral de Lugo. Julián Sanchez Bort. 1769. 


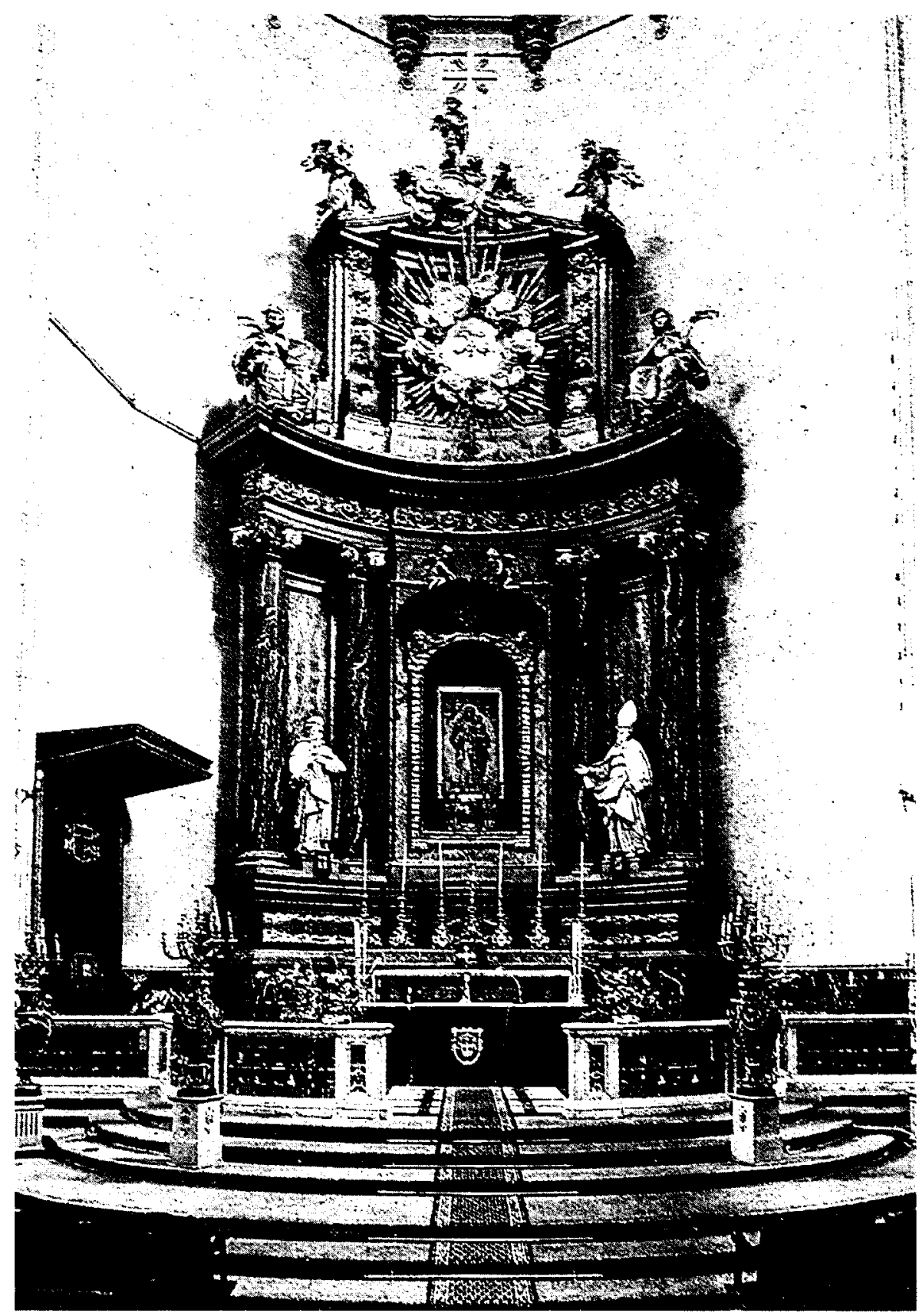

Fig. 20: Catedral de Segovia. Altar Mayor. Proyectado en 1768 por Sabatini. 


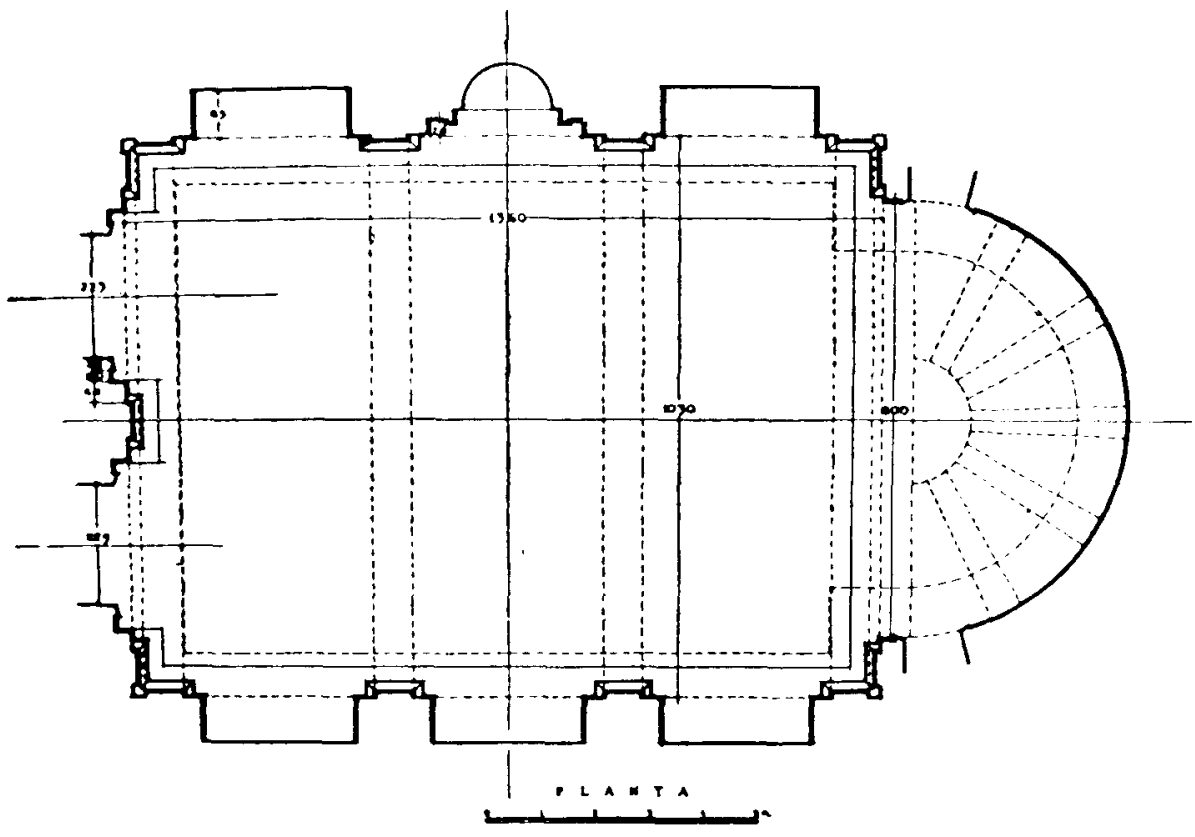

Fig. 21: Catedral de Burgo de Osma. Sacristia. Planta (según Chueca). Juan de Villanueva. Planos de 1770. 


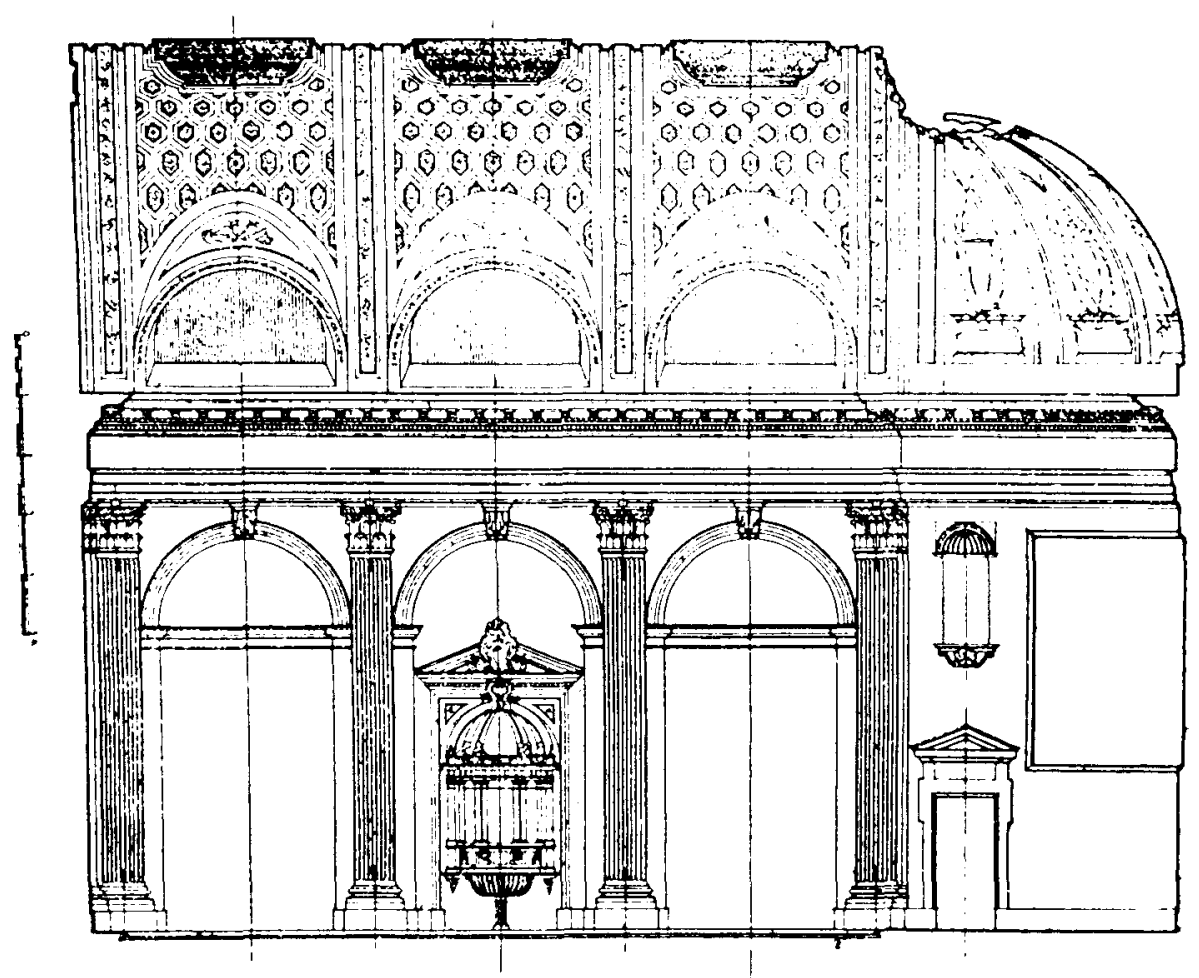

Fig. 22: Catedral de Burgo de Osma. Sacristía. Sección longitudinal (según Chueca). Juan de Villanueva. Planos de 1770. 


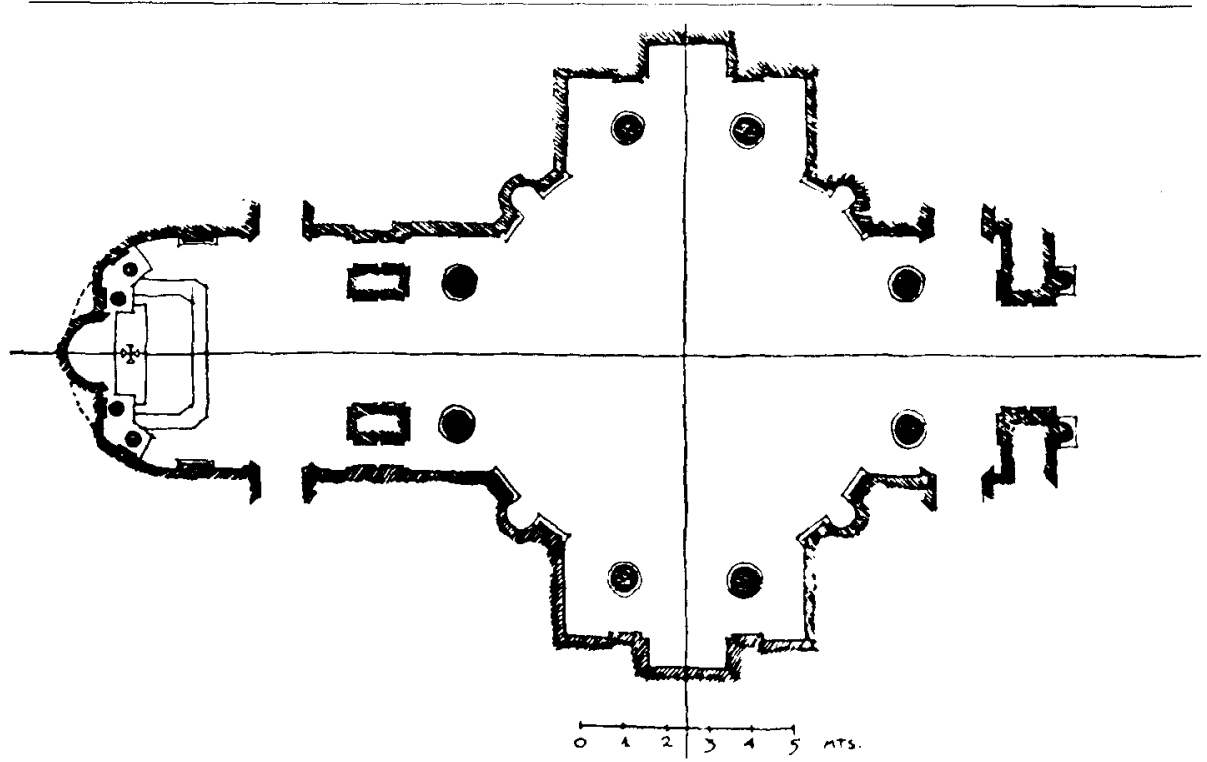

Fig. 23: Catedral de Burgo de Osma. Planta de la Capilla Palafox (segun Chueca). Juan de Villanueva. 1772-1783.

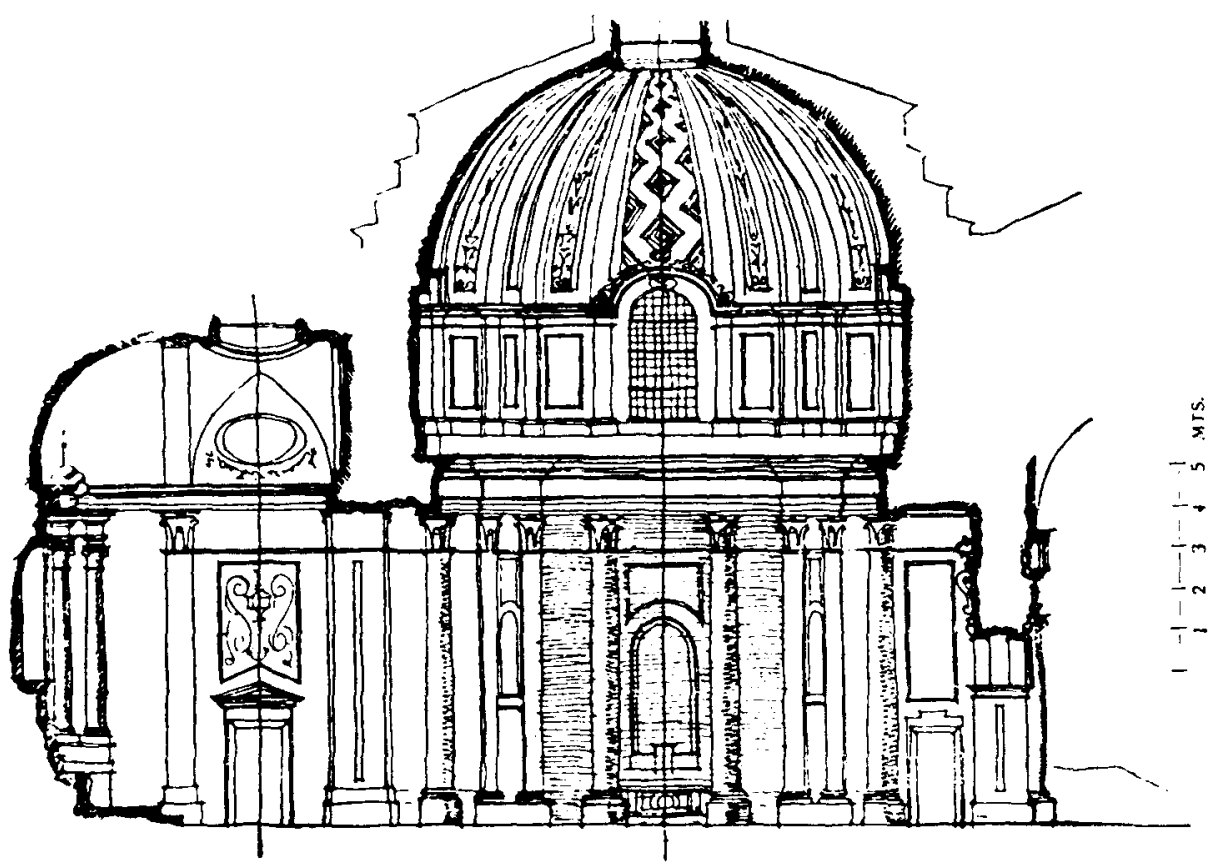

Fig. 24: Catedral de Burgo de Osma. Sección de la Capilla Palafox (segun Chueca): Juan de Villanueva. 1772-1783. 


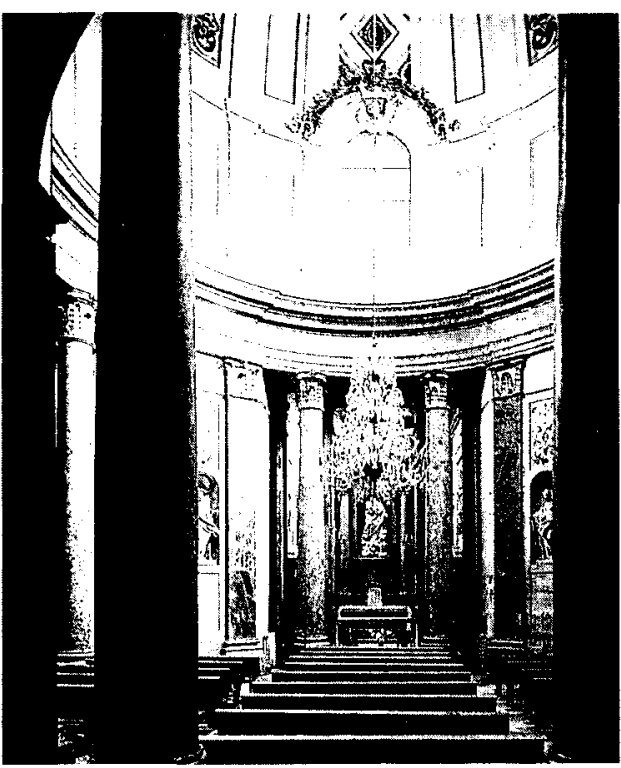

Fig. 25: Catedral de Burgo de Osma. Capilla del Venerable Palafox. Juan de Villanueva. 1772-1783.

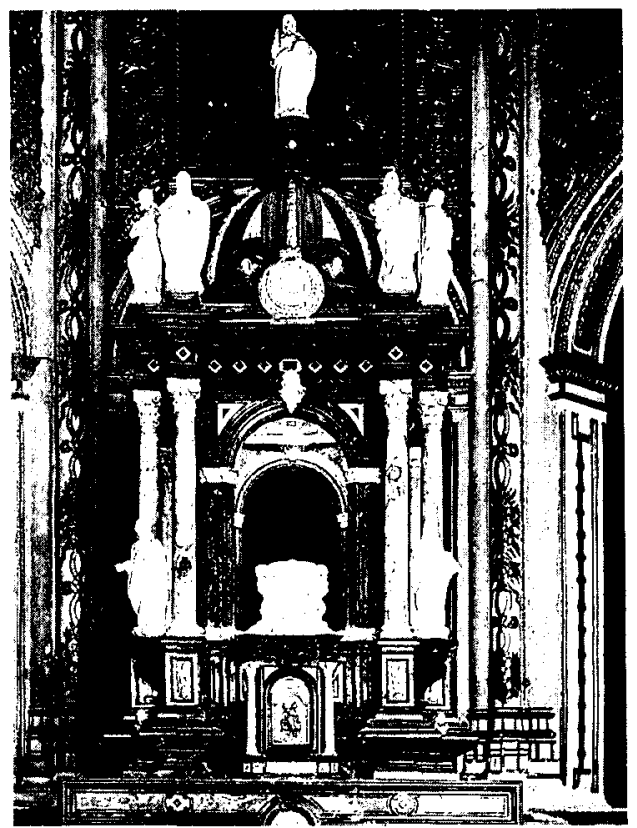

Fig. 27: Catedral de Almeria. Tabernáculo. Eugenio Valdez. Hacia 1773 y 1777

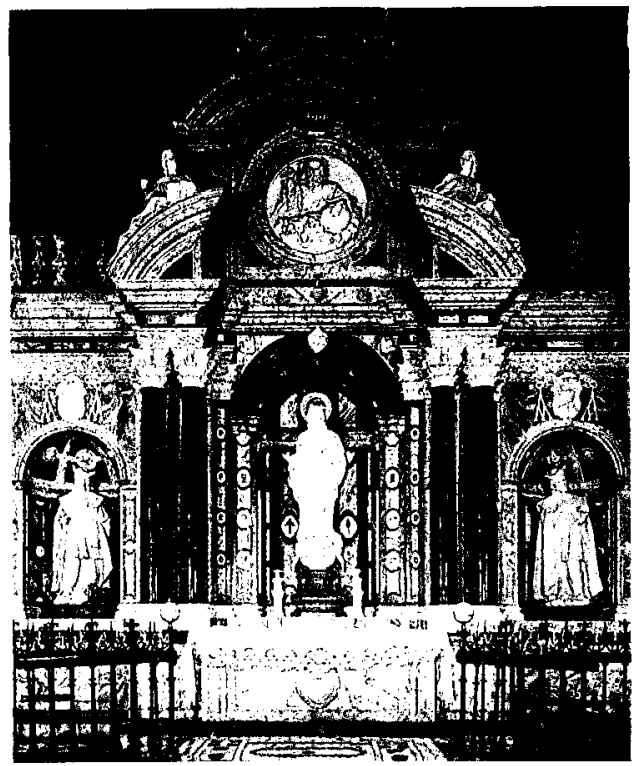

Fig. 26: Catedral de Almeria. Trascoro. Ventura Rodriguez y Eugenio Valdez. Hacia 1773 y 1777

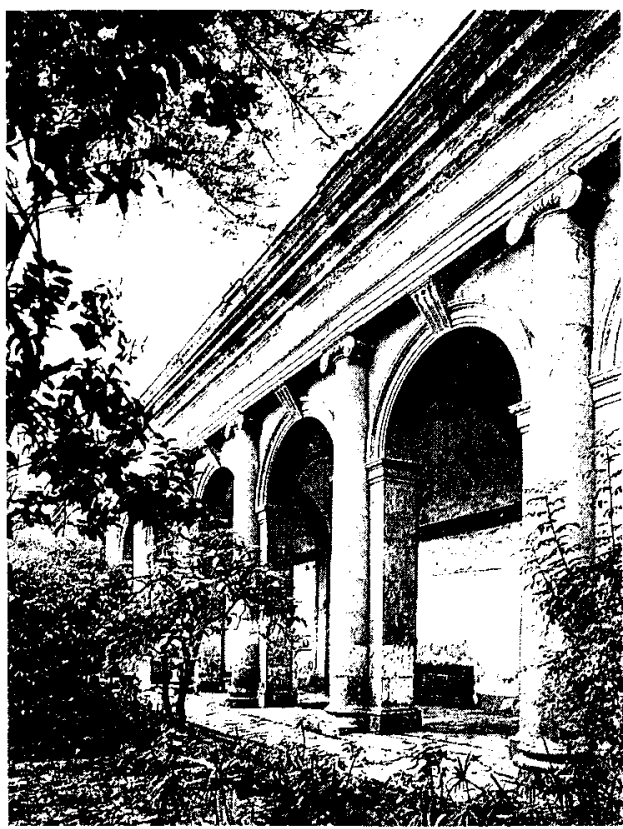

Fig. 28: Catedral de Almería. Claustro. Juan Antonio Munar. Proyecto de 1786. Terminación 1795. 

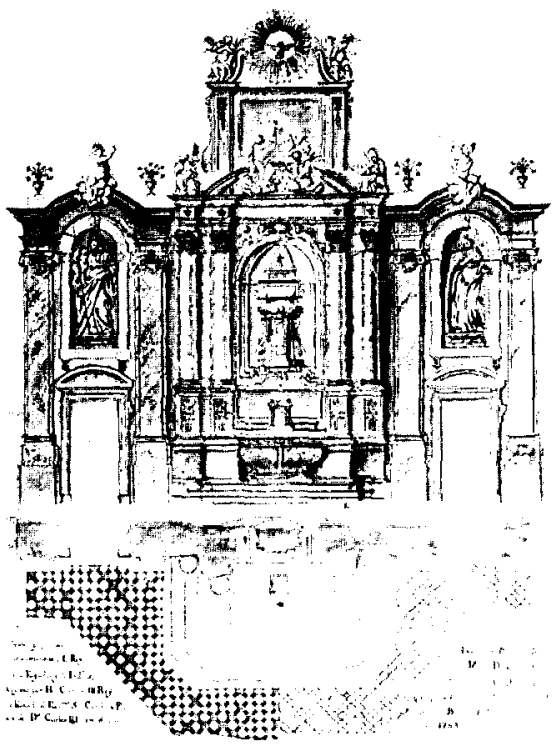

Fig. 29: Catedral de Segovia. Retablo para el Palacio de Riofrio de Huberto Demandre (1758). Planta y alzado por Joaquin Demandre (1782).
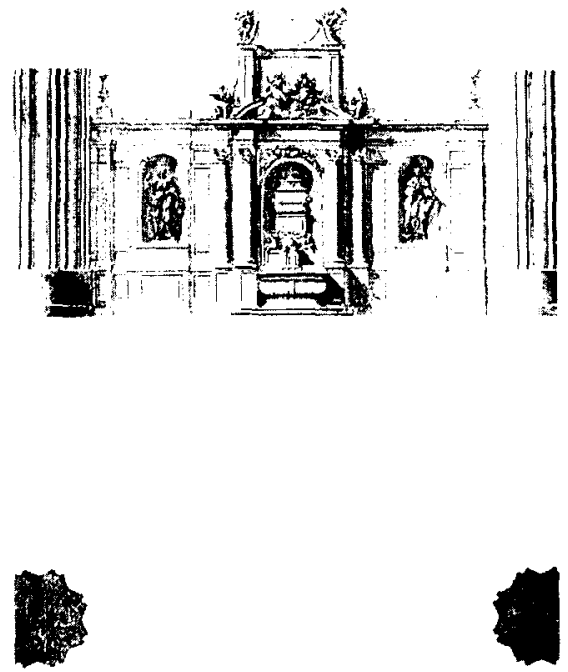

Fig. 31: Catedral de Segovia. Diseño del trascoro. Planta y alzado. Ventura Rodríguez. 4 de septiembre de 1784.

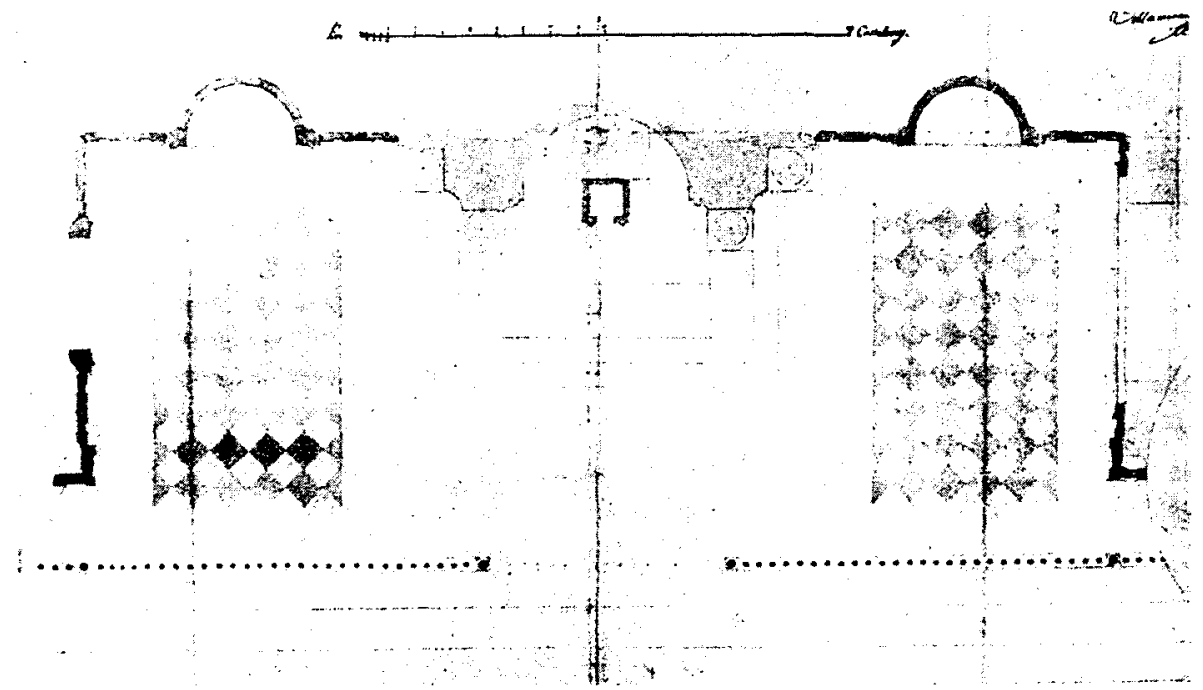

Fig. 30: Catedral de Segovia. Proyecto de capilla para adosar el retablo de Demandre al muro del trascoro. Juan de Villanueva. 1783. 


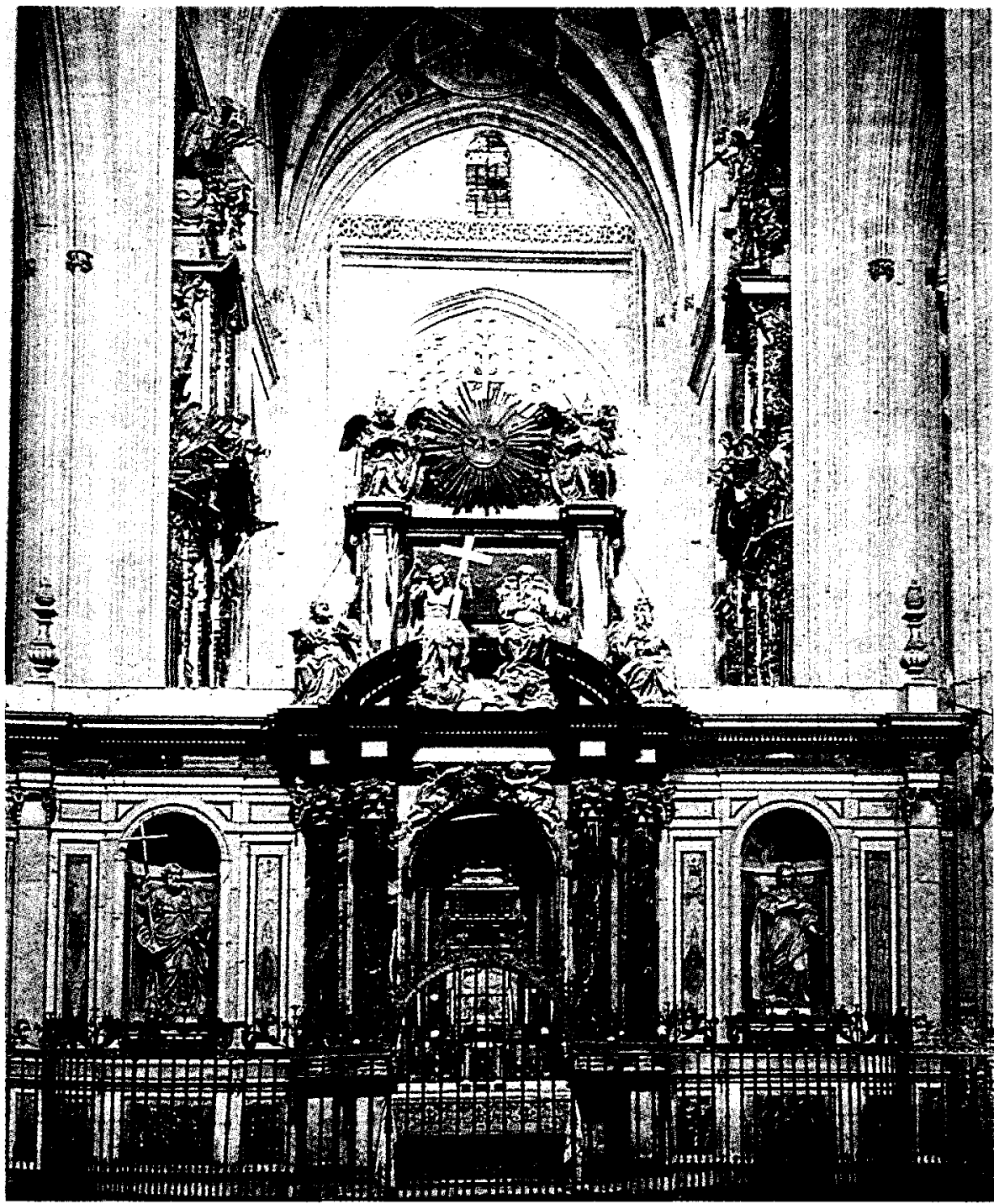

Fig. 32: Catedral de Segovia. Trascoro 1782-1784. 
Realizaciones arquitectónicas de la segunda mitad del siglo XVIII...

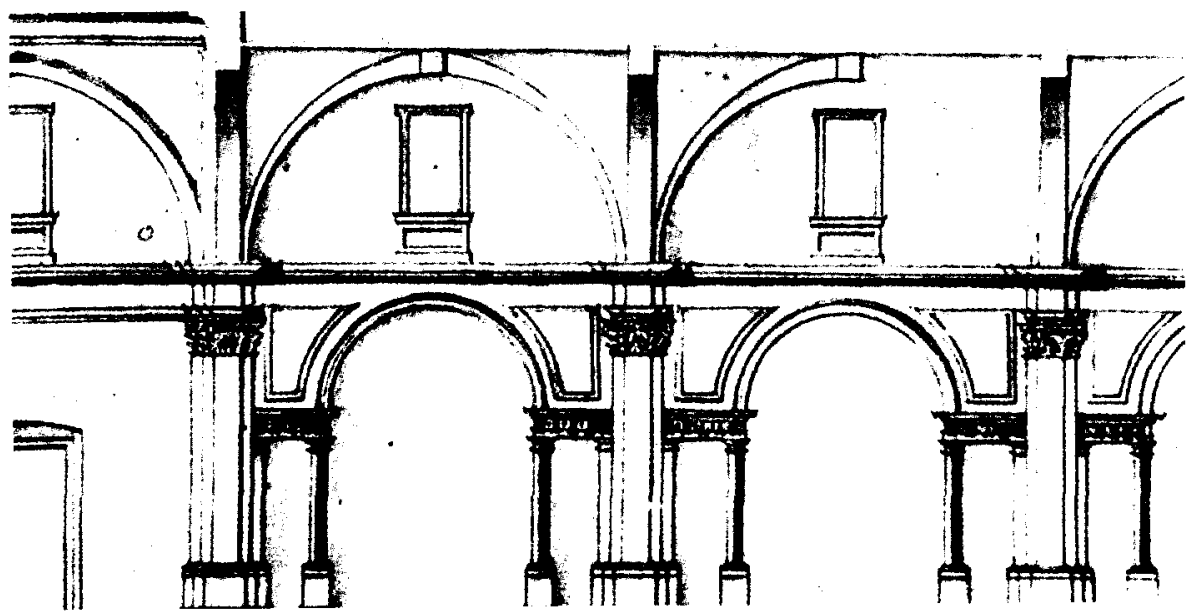

Fig. 33: Catedral de Valencia. Proyecto de remodelación. Antonio Gilabert. Hacia 1773.

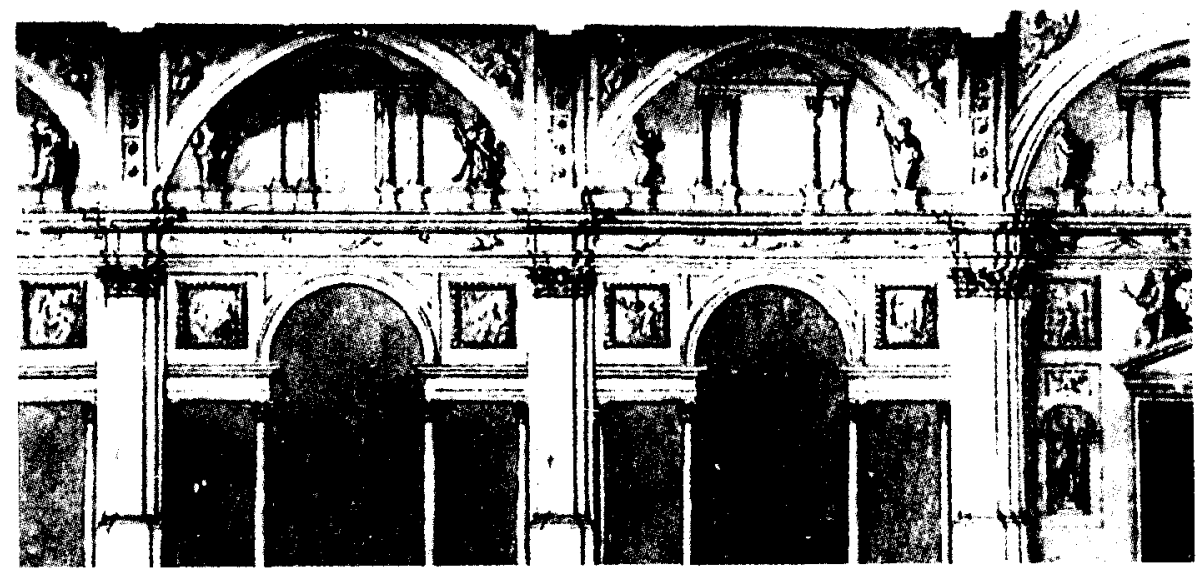

Fig. 34: Catedral de Valencia. Proyecto de remodelación. Vicente Gascó. Hacia 1773. 


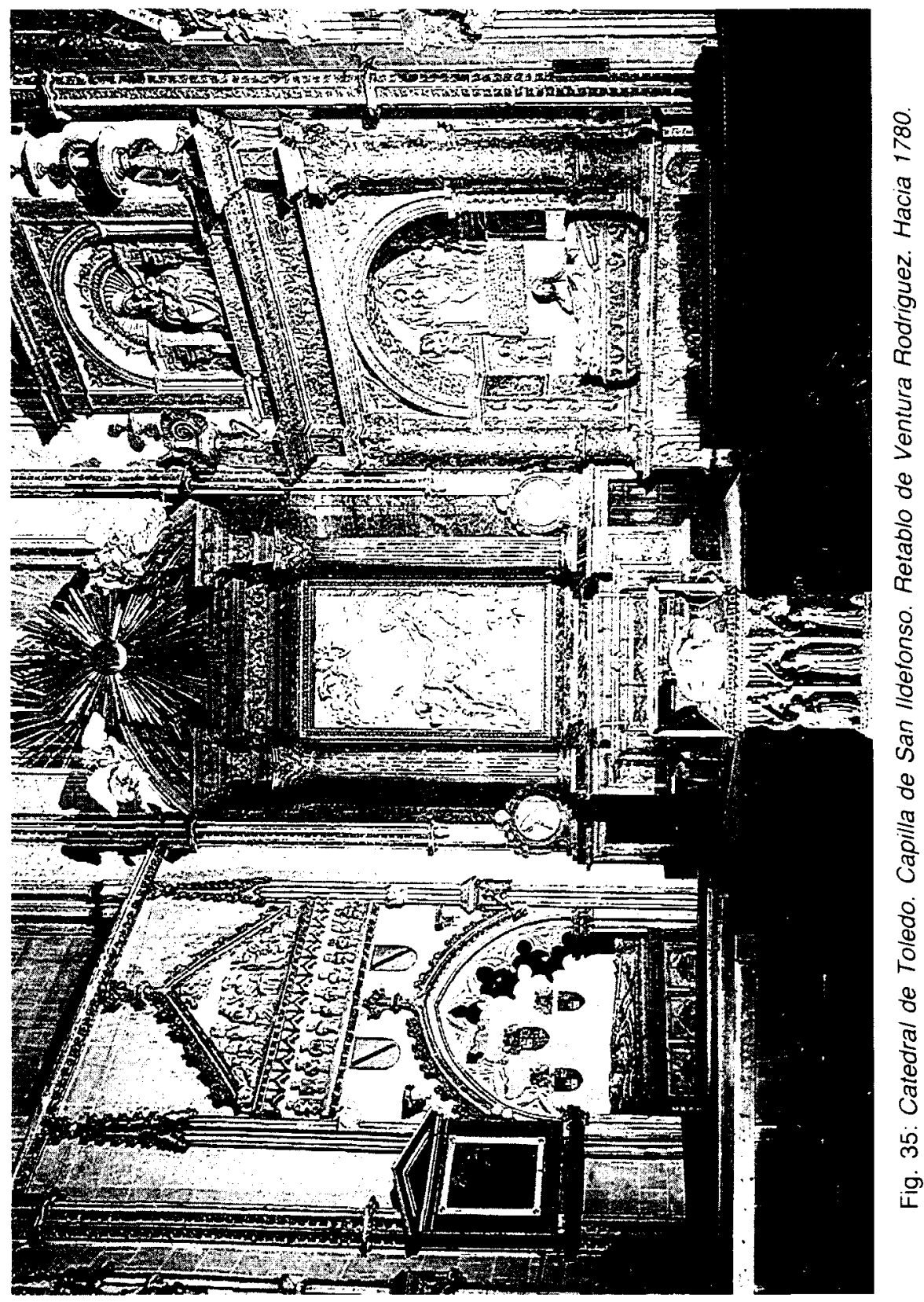

